UNIVERSIDADE DE SÃO PAULO

INSTITUTO DE GEOCIÊNCIAS

\title{
TECTÔNICA FANEROZOICA AO LONGO DA ZONA DE CISALHAMENTO JUNDIUVIRA, SP
}

Tiago Borges da Silva

Orientador: Prof. Dr. Claudio Riccomini

\author{
DISSERTAÇÃO DE MESTRADO
}

Programa de Pós-Graduação em Geoquímica e Geotectônica 


\author{
UNIVERSIDADE DE SÃO PAULO \\ INSTITUTO DE GEOCIÊNCIAS
}

\title{
TECTÔNICA FANEROZOICA AO LONGO DA ZONA DE CISALHAMENTO JUNDIUVIRA, SP
}

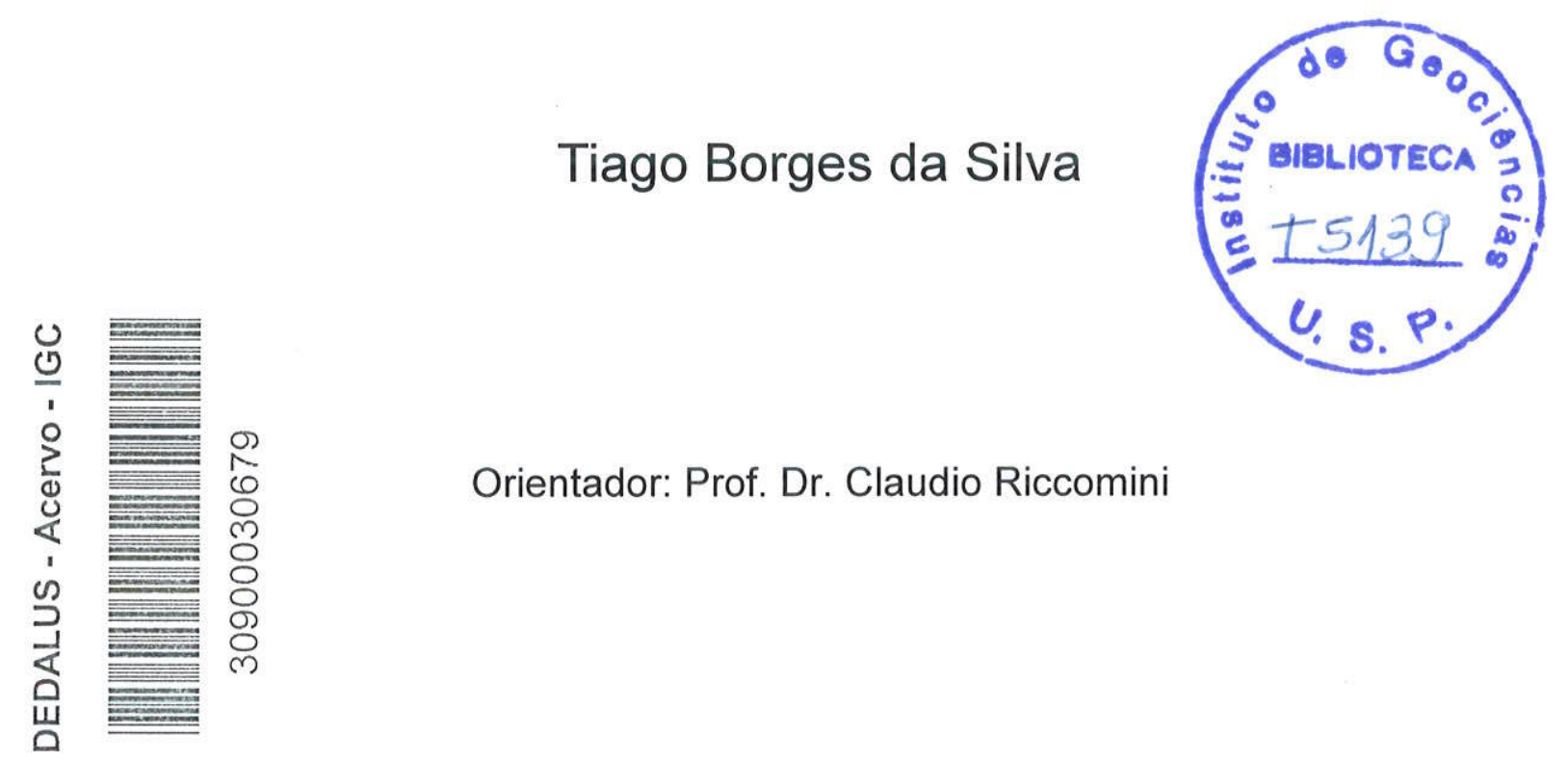

DISSERTAÇÃO DE MESTRADO

Programa de Pós-Graduação em Geoquímica e Geotectônica

SÃO PAULO 


\section{RESUMO}

A Zona de Cisalhamento Jundiuvira (ZCJ), com extensão reconhecida de aproximadamente $300 \mathrm{~km}$ na região centro-leste do Estado de São Paulo, é uma feição tectônica suavemente curviplanar de direção média ENE. Com traçado subparalelo à linha-de-costa e às grandes feições geológicas e geomorfológicas regionais, tais como as serras do Mar e da Mantiqueira, além do Rift Continental do Sudeste do Brasil, esta zona de cisalhamento possui grande importância na compartimentação do embasamento pré-cambriano da região, justapondo blocos ou terrenos de niveis crustais e naturezas diferentes.

De caráter dúctil no Neoproterozoico, a ZCJ foi posteriormente reativada, em nível crustal mais raso. Com base na análise estrutural de alvos selecionados, com rochas, sedimentos e paleossolos datados e situados na sua área de influência, a tectônica fanerozoica da ZCJ foi o objeto de estudo do presente trabalho, que visou a determinação de diferentes eventos de reativação e dos campos de esforços a eles relacionados.

Trabalhos prévios de mapeamento geológico apresentaram posições algo discrepantes para diferentes segmentos da ZCJ, o que exigiu a anáilise geomorfológica de modelos digitais de elevação, elaborados com base em dados do Shuttle Radar Topograpy Mission, para a melhor definição do traçado desta megaestrutura e escolha de um mapa base que guiasse a seleção de dados prévios da literatura e de alvos para os levantamentos estruturais de campo. Foram selecionados como alvos o Granito de Itu, ediacarano, a Bacia do Pico de ltapeva, ediacarana a cambriana, rochas permocarboníferas do Grupo Itararé, na borda leste da Bacia do Paraná, o Maciço Alcalino de Passa Quatro, neocretáceo, e depósitos coluviais e paleossolos quaternários do Planalto de Campos do Jordão.

Baseado em trabalhos de campo e análise de dados preexistentes foram caracterizados episódios de reativações fanerozoicas, assim distribuídos: distensão NW-SE no Ediacarano-Cambriano, transpressão destral resultante de encurtamento na direção E-W a WNW-ESSE de provável idade ordoviciana, transcorrência destral com direção de compressão NE-SW e idade neocretácea, distensão com direção geral NW-SE de idade eocena-oligocena ou miocena, transcorrência destral com direção de compressão NW-SE e idade 
pleistocena terminal a holocena, e deformações com SHmáx alternado segundo as direções NE-SW e NW-SE de idade holocena.

O desenvolvimento do trabalho permitiu também demonstrar que, ao menos na área de influência da ZCJ, as deformações registradas em rochas do Grupo Itararé são de origem tectônica e desvinculadas de glaciotectonismo. A colocação de diques de rochas alcalinas neocretáceos no Maciço Alcalino de Passa Quatro parece ter respondido a um controle tectônico duplo, da ZCJ para os diques de direção NW-SE, e do Alinhamento Magmático de Cabo Frio para os diques de direção NE-SW. No Planalto de Campos do Jordão foram reconhecidas falhas possivelmente cossísmicas e com intervalo de recorrência da ordem de $10^{3}$ anos, além de deformações holocênicas dispostas de forma provavelmente contínua por pelo menos $10 \mathrm{~km}$ ao longo da ZCJ, o que apresenta implicações para a paleossismicidade regional.

O desenvolvimento do presente estudo permitiu estabelecer um quadro inicial das diferentes deformações ocorridas ao longo da ZCJ durante o Fanerozoico. o refinamento deste quadro depende da descoberta de novos depósitos falhados e do maior aporte de dados geocronológicos. 


\section{ABSTRACT}

The Jundiuvira Shear Zone (JSZ), with a length of approximately $300 \mathrm{~km}$ in the central-eastern part of the State of São Paulo, Brazil, is a gentle arcuate curviplanar tectonic feature in a general ENE-trending. It subparallels the present-day coastline as well as the main geologic and geomorphologic features, such as the serras do Mar and Mantiqueira ranges and the Continental Rift of Southeastern Brazil. The JSZ played a major role in the compartmentation of the Precambrian basement rocks of the region and is responsible for the juxtaposition of blocks or terrains of different nature and crustal levels.

With a ductile behaviour during the Neoproterozoic, the JSZ was reactivated in shallow crustal levels afterwards. The present study aimed to decipherate the Phanerozoic tectonics, reactivation episodes and their respective stress-fields along the JSZ, based on structural analysis of selected targets with dated rocks, sediments and paleosols distributed in the area of influence of this shear zone.

Available geologic maps showed somewhat discrepant tracks in different segments of the JSZ. Geomorphologic analysis of digital elevation models elaborated using the data from Shuttle Radar Tography Mission was performed in order to better delineate this megastructure, and in choosing a base-map as a guide to select previous data from literature as well as the targets for field structural analysis. The selected targets are as follows: the Ediacaran Itu Granite; the Ediacaran to Cambrian Pico de Itapeva Basin; the Permocarboniferous sedimentary rocks of the Itarare Group, in the eastern part of the Paraná Basin; the Late Cretaceous Passa Quatro alkaline massif; and Quaternary colluvium and paleosols covering the JSZ in the Campos do Jordão plateau.

Field survey and available data allowed to recognize different episodes of Phanerozoic fault reactivation along the JSZ. During the Ediacaran the shear zone was subject to a NW-SE-oriented extension. It was followed by a rightlateral transpression with an E-W to WNW-ESE-oriented shortening of a probable Ordovician age. A right-lateral transcurrence with a NE-SW-oriented extension tooks place during the Late Cretaceous. A NW-SE-trending extension was active during the Eocene-Oligocene or in the Miocene. More recent 
deformations comprise a right-lateral strike-slip faulting during the Late Pleistocene and the Holocene, and deformations with SHmax in orthogonal positions, NE-SW and NW-SE-oriented, of Holocene age.

This study also demonstrates that, at least in the area of influence of the JSZ on the overlying sedimentary rocks of the Itararé Group, the deformations are of tectonic origin, without relationships to glaciotectonism. The emplacement of alkaline dikes in the Passa Quatro massif seems to have occurred as a response to a double tectonic control, the JSZ to the NW-SEoriented and the Cabo Frio Magmatic Alignement to the NE-SW-trending dikes. Possible coseismic faulting, with a $10^{3}$ years reccurrence time, as well as evidence of surface rupture for at least $10 \mathrm{~km}$ along the JSZ were recognized in the Campos do Jordão plateau, with implications for regional paleoseismicity.

Finally, the development of this work allowed to define a rough sketch of the different deformations along the Jundiuvira Shear Zone during the Phanerozoic. The improvement of this model depends on discovering new occurrence of faulted rocks, deposits and paleosols as well as of new geochronological data. 


\section{AGRADACIMENTOS}

O autor gostaria de expressar seus sinceros agradecimentos às pessoas que ajudaram direta ou indiretamente na concepção desta dissertação.

Ao professor Dr. Claudio Riccomini pela orientação, grande ajuda com interpretação dos dados e correção do texto.

Aos amigos, extremamente presentes, Luiz Fernando Roldan, Carlão, Gabriel, Samar e Marlei por literalmente colocarem a mão na massa, dando sugestões sobre o texto, auxiliando na operação de diversos softwares e participando de viagens ao campo. Além desses, outros amigos que sempre apoiaram e ofereceram ajuda caso necessário.

Aos funcionários da gráfica do Instituto de Geociências - USP, sempre preparados para emergências.

Ao grande e infinito apoio dos meus pais, que mesmo distantes, sempre demonstraram interesse e preocupação.

Finalmente a Débora pelas correções gramaticais, força, paciência e enorme companheirismo durante os momentos difíceis que superamos juntos. 


\section{SUMÁRIO}

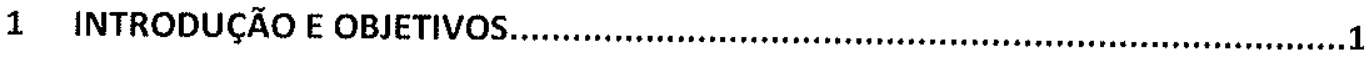

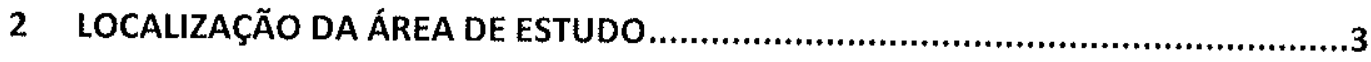

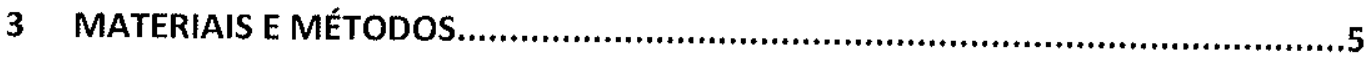

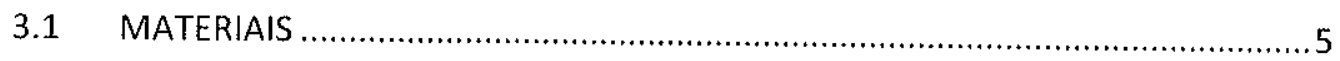

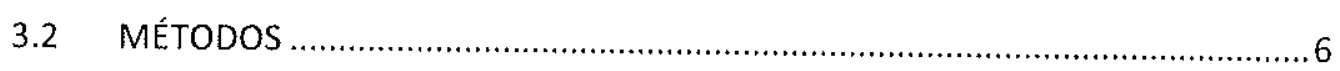

3.2.1 VETORIZAÇÃO DE CARTAS TOPOGRÁFICAS, GEOLÓGICAS E DADOS DE

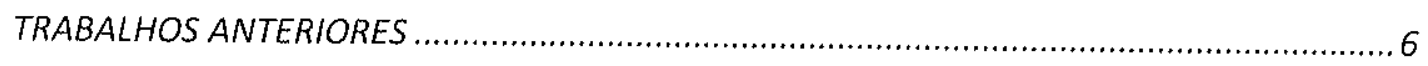

3.2.2 MODELO DIGITAL DE ELEVAÇÃO …....................................................

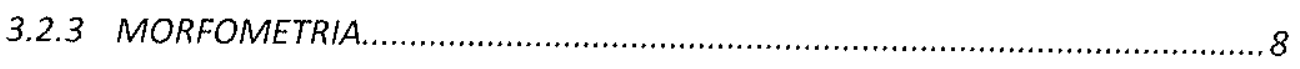

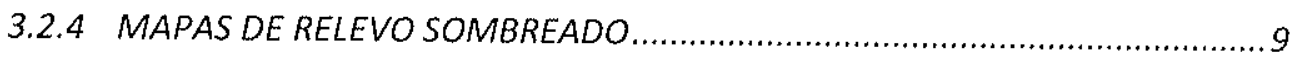

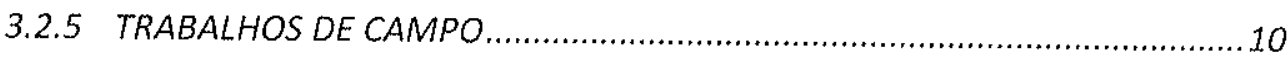

3.2.6 ANÁLISE DE DADOS ESTRUTURAIS ................................................. 11

4 CONTEXTO GEOLÓGICO E TECTÔNICO REGIONAL ..........................................25

4.1 AS PRINCIPAIS UNIDADES LITOESTRATIGRÁFICAS RELACIONADAS À ZONA DE

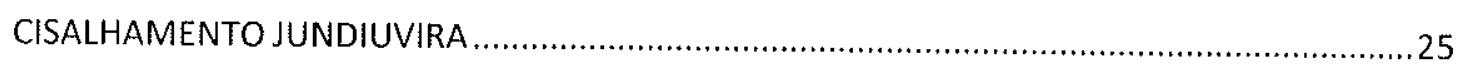

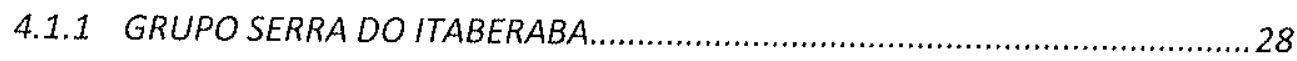

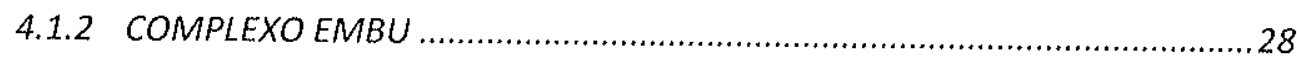

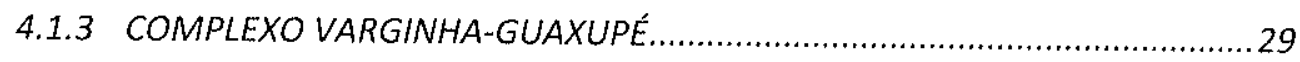

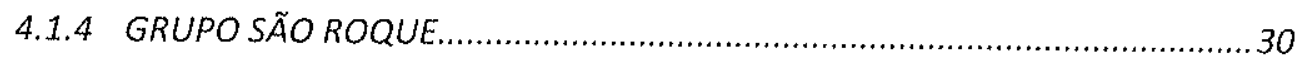

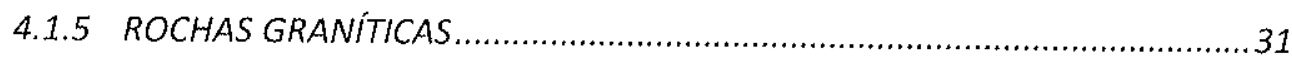

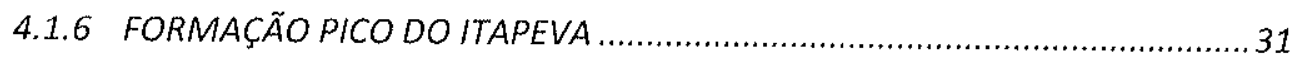

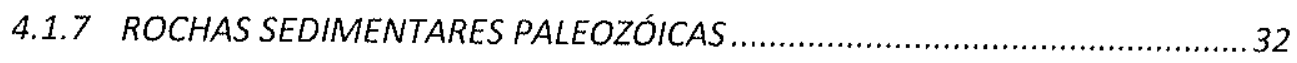

4.1.8 COMPLEXO PLUTÔNICO ALCALINO DE PASSA QUATRO...........................32

4.1 .9 DEPÓSITOS SEDIMENTARES CENOZÓICOS ...............................................33

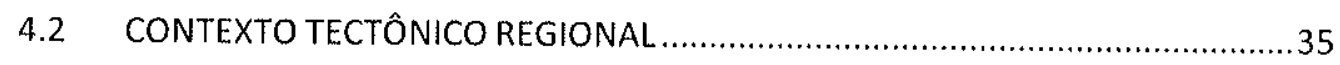

4.2.1 AS GRANDES ZONAS DE CISALHAMENTO DO ESTADO DE SÃO PAULO .......36

4.2.2 REATIVAÇÕES FANEROZOICAS DE ZONAS DE CISALHAMENTO ....................38

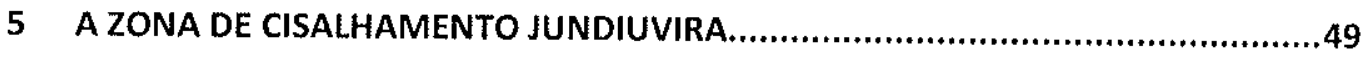

6 REATIVAÇÃO FANEROZOICA DA ZONA DE CISALHAMENTO JUNDIUVIRA...........57

6.1 ROCHAS SEDIMENTARES DO GRUPO ITARARÉ ........................................5 
6.1.1 INTRODUÇÃO.

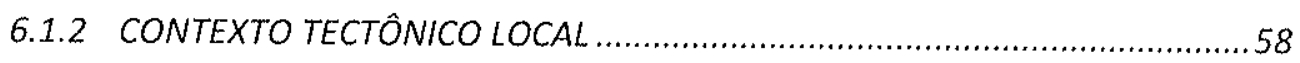

6.1.3 DEFORMAÇÃO RÚPTIL EM ROCHAS DO GRUPO ITARARÉ NA REGIÃO DE ITU. 60

6.2 GRANITO PÓS-OROGÊNICO ITU 68

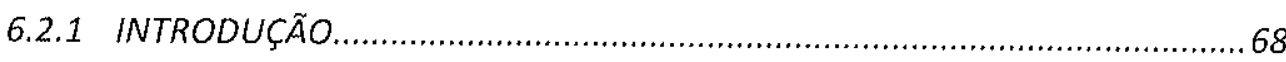

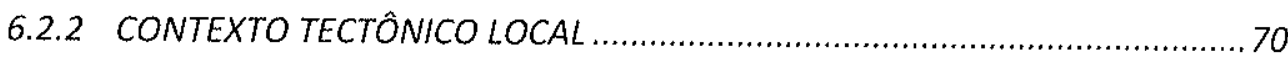

6.2.3 ANÁLISE CINEMÁTICA E PALEOTENSÕES NO GRANITO ITU ASSOCIADAS À ZONA DE CISALHAMENTO JUNDIUVIRA 71

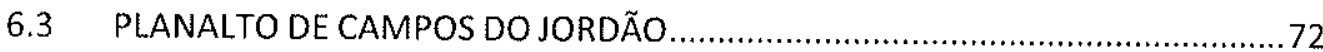

6.3.1 BACIA EDIACARANA DO PICO DO ITAPEVA ............................................. 72

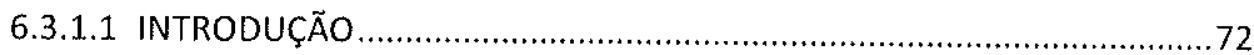

6.3.1.2 CONTEXTO TECTÔNICO LOCAL ........................................................... 74

6.3.1.3 ANÁLISE CINEMÁTICA E PALEOTENSÕES NA BACIA DO PICO DE ITAPEVA ASSOCIADAS À ZONA DE CISALHAMENTO JUNDIUVIRA .75

6.3.2 DEPÓSITOS QUATERNÁRIOS DO PLANALTO DE CAMPOS DO JORDÃO .......77

6.3.2.1 EVOLUÇÃO TECTÔNICA LOCAL .78

6.3.2.2 ANÁLISE CINEMÁtICA E PALEOTENSÕES EM DEPÓSITOS QUATERNÁRIOS DISPOSTOS SOBRE A ZONA DE CISALHAMENTO JUNDIUVIRA 80

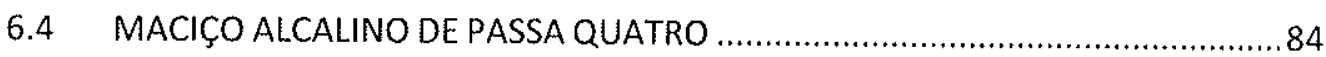

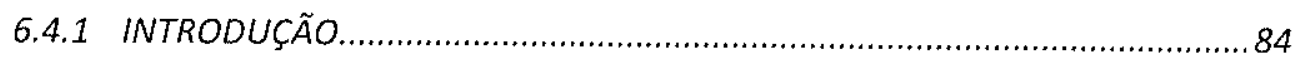

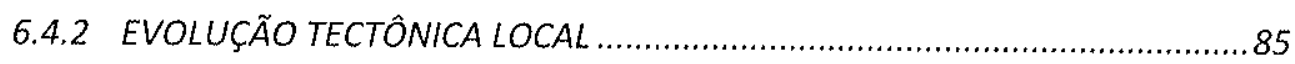

6.4.3 ANÁLISE CINEMÁTICA E PALEOTENSÕES ASSOCIADAS À ZONA DE CISALHAMENTO JUNDIUVIRA NO MACIÇO ALCALINO DE PASSA QUATRO. 88

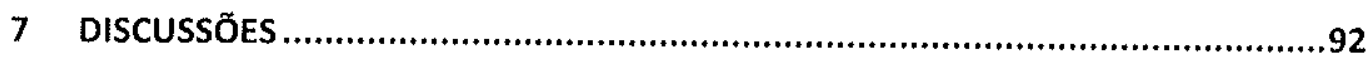

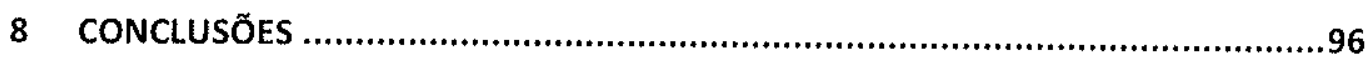

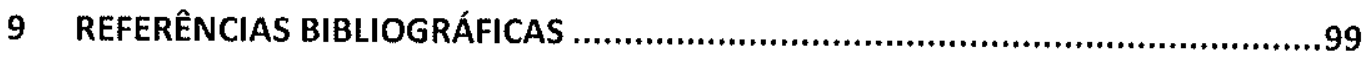




\section{LISTA DE FIGURAS}

FIGURA 1 - MAPA ESQUEMATICO COM A LOCALIZAÇÃO DA ZCJ E AS AREAS ESTUDADAS ........................................ 4

FIGURA 2 - FEIÇÕES DE RELEVO ASSOCIADAS À MOVIMENTAÇÃO TECTÓNICA (MODIFICADO DE SUMMERFIELD 1993)........... 9

FIGURA 3 - MAPAS DE RELEVO SOMBREAdo, ONDE OS ILUMINANTES ESTÃo POSICIONADOS EM NORTE (ACIMA) E OESTE

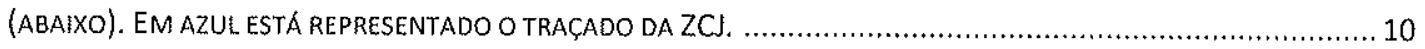

Figura 4-MÉTOdo dOS DIEDROS RETOS. I) FALHA (F) E PLANO AUXILIAR (A) DELIMITANDO DIEDROS COMPRESSIVOS (C) E DISTENSIVOS (D). A DIREÇÃO E O SENTIDO DE MOVIMENTO DA FALHA ESTÃO REPRESENTADOS PELO VETOR UNITARIO DE MOVIMENTO (S) E VETOR UNITARIO ORTOGONAL A FALHA (N); (II) PROJEÇÃO ESTEREOGRÁfICA dOS PLANOS F E A, ONDE B É A INTERSECÇÃO DOS DOIS, CÉ O DIEDRO COMPRESSIVO E D O DISTENSIVO. III) OS DOIS PRIMEIROS DIAGRAMAS REPRESENTAM UMA FALHA NORMAL E OUTRA DIRECIONAL; O TERCEIRO É A SUPERPOSIÇÃO DE AMBOS. AS AREAS EM CINZA REPRESENTAM 100\% DE COMPRESSÃO, AS ÁREAS PONTILHADAS 100\% DE DISTENSÃO E BRANCO SÃO DOMINIOS ONDE OCORRE COMPRESSÄO E DISTENSÃO. EXTRAIDO DE ANGELIER (1994) 13

FIGURA 5 - CRITERIO PARA DETERMINAÇÃO DE RELAÇÃO CRONOLOGICA ENTRE DIFERENTES FAMILIAS DE JUNTAS. (A) JUNTA PRETÉRITA DESLOCADA POR FALHA; (B) JUNTA MAIS JOVEM COM TERMINAÇÃO EM JUNTA ANTIGA; (C) JUNTAS ANTIGAS CORTADAS POR JUNTA JOVEM DE ATITUDE DIFERENTE; (O) SUCESSÃO CRONOLOGGCA INDEFINIDA APENAS PELA RELAÇÃO DE CORTE ENTRE DIFERENTES JUNTAS. EXTRAIDO DE DUNNE \& HANCOCK (1994). 14

FIGURA 6 - CLASSIFICAÇÃO GEOMÉTRICA DE JUNTAS. EXTRAIDO DE DUNNE \& HANCOCK (1994). 15

FIGURA 7 - DIAGRAMA MOHR-COULOMB. OS CIRCULOS TRACEJADOS REPRESENTAM: (A) JUNTAS DE DISTENSÄO, (B) JUNTAS HIBRIDAS, (C) JUNTAS DE CISALHAMENTO. EXTRAIDO DE ROLDAN (2007), SEGUNDO PRICE \& COSGROVE (1990), ... 16

FIGURA 8 - RELAÇÃO ANGULAR ENTRE OS TRÊS EIXOS PRINCIPAIS DE ESFORÇOS E JUNTAS FORMADAS...... 16

FIGURA 9 - CLASSES DE JUNTAS E RELAÇÃO GEOMÉTRICA ENTRE OS EIXOS DE ESFORÇO MÁXIMO E MINIMO. (A) JUNTAS DE DISTENSÃO; (B) JUNTAS CONJUGADAS HIBRIDAS; (C) JUNTAS CONJUGADAS DE CISALHAMENTO; (D) ESPECTRO DE JUNTAS - DISTENSÄO E HIBRIDAS EM CONJUNTO. MODIFICADO DE DUNNE \& HANCOCK (1994).

FIGURA 10 - CROQUIS ESQUEMÁTICOS DA FORMAÇÃO PROGRESSIVA EM SEIS EVENTOS DO SISTEMA GRID-LOCK, COMPOSTO POR FAMILIAS DE DIREÇÃO ORTOGONAL. MODIFICADO DE CHIESSI (2004), SEGUNDO DE CAPUTO (1995). 18

FIGURA 11 - CLASSIFICAÇÃO DOS PRINCIPAIS TIPOS DE FALHAS: A) FALHA NORMAL; B) FALHA TRANSCORRENTE; C) FALHA INVERSA. MODIFICADO DE ANDERSON (1951).

FIGURA 12 - EXEMPLOS DE CRITÉRIOS PARA A DETERMINAÇÃO CINEMÁTICA EM PLANOS DE FALHAS: A) DEGRAUS FORMADOS PELO CRESCIMENTO MINERAL (NEOFORMADOS); B) MARCAS DE OBJETOS; C) FALHAS SINTÉTICAS (R); D) FALHAS ANTITÉTICAS (R'); E) FACETAS POLIOAS E RUGOSAS; F) "TENSION GASHES", FRATURAS TIPO T; G) PICOS OU LINEAÇDES ESTILOLITICAS, FORMADAS POR DISSOLUÇÕES; H) MARCAS PARABÓLICAS COM A CONCAVIDADE NO SENTIDO DO MOVIMENTO DO BLOCO ABATIDO;1) VESICULAS DEFORMADAS EM LAVAS. EXTRAIDO DE ANGEUER (1994). 20

FIGURA 13 - CRITÉRIOS PARA DETERMINACÁO CINEMATICA NO CONTEXTO DE CISALHAMENTO SIMPLES, SEGUNDO PETIT (1987).

FIGURA 14 - ILUSTRAÇÄO PARA ESTRUTURAS SECUNDÁRIAS RESULTANTES DE UM BINÁRIO DESTRAL EM CONTEXTO DE CISALHAMENTO SIMPLES - MODELO DE RIEDEL, SEGUNDO PETIT (1987). 
FIGURA 15 - EUIPSOIDE DE DEFORMAÇÃO EM BINARIO DESTRAL ILUSTRANDO ESTRUTURAS SECUNDARIAS: A) FALHAS SINTÉTICAS; B) fALHAS ANTITÉTICAS; X) FALHAS INVERSAS; Y) DOBRAS E DIÁPIROS; T) FALHAS NORMAIS, DIQUES $E$ DIÁCLASES. MODIFICADO DE ZALAN (1986). 22

FIGURA 16 - ESTRUTURAS SECUNDARIAS EN ECHELON ASSOCIADAS A UMA ZONA DE CISALHAMENTO DESTRAL. AS ESTRUTURAS COMPILADAS SÃO: A) FALHAS SINTÉTICAS E ANTITÉTICAS; B) DOBRAS; C) FRATURAS DE DISTENSÃO; D) FALHAS DE EMPURRÃO; E) SOBREPOSICAAO DAS ESTRUTURAS ANTERIORES. SEGUNDO SYLVESTER (1988).

FIGURA 17 - MORFOLOGIA DE DIQUES RELACIONADOS À VARIAÇÃO ESPACIAL DO MENOR VETOR DE ESFORÇO COMPRESSIVO ( $\left.\Sigma_{3}\right)$ E: A) MODO PURO I: APRESENTA $\Sigma_{3}$ COM DIREÇÃO CONSTANTE PERPENDICULAR AO PLANO DO DIQUE - DIQUE PLANAR; B) MOOO MISTO I-II: ROTAÇÃO DO $\Sigma_{3}$ SEGUNDO EIXO PARALELO A DIREÇÃO PLANAR DO DIQUE - DIQUE CURVADO; C) MODO MISTO I-III: ROTAÇÃO DO $\Sigma_{3}$ SEGUNDO O EIXO DE PROPAGAÇÃO DO DIQUE - DIQUE SEGMENTADO. EXTRAIDO DE CHESSE (2004), SEGUNDO POLLARD (1987). 25

FIGURA 18 - MAPA GEOLÓGICO REGIONAL SIMPLIFICADO DE PARTE DAS UNIDADES GEOLÓGICAS PRESENTES NA PORÇÃO CENTRO-LESTE DO ESTADO OE SÃO PAULO; EM VERMELHO O TRACCADO DA ZCJ. MODIFICADO DE CPRM (2006) .....27

FIGURA 19 - MAPA GEOLÓGICO DO SEGMENTO CENTRAL DO RIFT CONTINENTAL DO SUDESTE DO BRASIL. 1) EMBASAMENTO PRÉ-CAMBRIANO; 2) FORMAÇÃO RESENDE - SISTEMA DE LEQUES ALUVIAIS PROXIMAIS; 3) FORMAÇÃO RESENDE SISTEMA DE LEQUES ALUVIAIS MEDIANO E DISTAIS ASSOCIADOS A PLANICIE ALUVIAL DE RIOS ENTRELAÇADOS; 4)

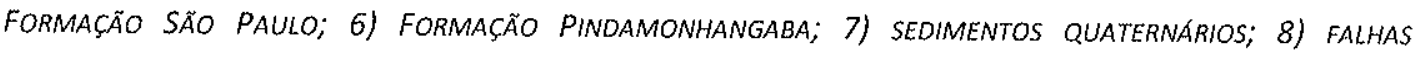
CENOZOICAS REATIVADAS DO EMBASAMENTO PRÉ-CAMBRIANO; 9) EIXOS DE DOBRAS PRINCIPAIS. EXTRAIDO DE RICCOMINIET AL. 2004, SEGUNDO RICCOMINI 1989.

FIGURA 20 - SUBDIVISÃO dO SISTEMA OROGENICO MANTIQUEIRA. SEGMENTO SETENTRIONAL: ORÓgeNo ARAÇAI; SEGMENTO CENTRAL: ORÓGENOS BRASILIA MERIDIONAL, RIBEIRA E APIAI; SEGMENTO MERIDIONAL: ORÓGENOS DOM FELICIANO E SÃo GABRIEL. EXTRAIDO DE HELLBRON ETAL. (2004). 35

FIGURA 21 - MAPA DE LOCALIZAÇÃO DAS PRINCIPAIS ZONAS DE CISALHAMENTO NO ESTADO DE SÃO PAULO. MODIFICADO DE CPRM (2006).

FIGURA 22 - ARCABOUÇO tECTÓNICO DA BACIA DO PARANÁ E GRANDES ELEMENTOS ESTRUTURAIS DE DIREÇÃO NE-SW. EXTRAIDO DE MILANI 2004.

FIGURA 23 - ALINHAMENTO MAGMÁTICO DE CABO FRIO COM DISTRIBUIÇÃO E IDADE DOS CORPOS ALCALINOS. EXTRAIDO DE RICCOMINIET AL. (2004).

FIGURA 24 - QUADRO UTOESTRATIGRÁFICO E EVOLUÇÃO TECTONNICA NA PORÇÃO CENTRAL DO RIFT CONTINENTAL DO SUDESTE DO BRASIL. EXTRAIDO DE RICCOMINIET AL. (2004).

FIGURA 25 - ESBOÇOS PALEOTECTÓNICOS DA EVOLUÇÃO DO RIFT CONTINENTAL DO SUDESTE DO BRASIL - LEGENDA NO QUADRO D: 1) FALHAS DE COMPONENTE PREDOMINANTE NORMAL; 2) FALHA DE COMPONENTE TRANSCORRENTE SINISTRAL; 3) FALHA DE COMPONENTE TRANSCORRENTE DESTRAL; 4) FALHA DE COMPONENTE PREDOMINANTEMENTE INVERSA; 5) FALHA COM MOVIMENTAÇÃO NÄO CARACTERIZADA. FONTE: MODIFICADO DE RICCOMINI (1989) E RICCOMINI ETAL. (2004). 45

FIGURA 26 - MAPA DE SISMICIDADE DO SUDESTE DO BRASIL EM ESCALA 1 : 5.000.000. MODIFICADO DE IAG 2011 ...... 48 FIGURA 27 - MAPA TECTONICO DO SEGMENTO CENTRAL DO SISTEMA OROGËNICO MANTIQUEIRA. 1) RIFTS CENOZÓICOS; 2) ROCHAS ALCALINAS DO CRETACEO E TERCIÁRIO; 3) E 4) ORÓGENO BRASILIA: 3 - NAPPES INFERIORES E 4 - NAPPES 
SUPERIORES; 5) EMBASAMENTO dO CRATON DO SÃO FRANCISCO E DOMINIO AUTOCCTONE; 6) SUPER GRUPO SÃO FRANCISCO; 7) METASSEOIMENTOS DO DOMINIO AUTÓCTONE; 8) A 13) OROGENO RIBEIRA: 8 - DOMINIO ANDRELANDIA, 9 - DOMINIO JUIZ DE FORA, 10 - KIPPLE PARAIBA DO SUL, 11 - TERRENO ORIENTAL, 12 Granitóldes do arco Magmático Rio negro, 13 - Terreno Cabo frio; 14) e 15) Orógeno apiaí PARANAPIACABA: 14 - TERRENOS SÃo ROQUE E AÇUNGUI, 15 - TERRENO EMBU. MODIFICADO DE HEILBROM ET AL. (2004). .50

FIGURA 28-ZCJ EM MODELO DIGITAL DE ELEVAÇÃO DO LESTE DO ESTADO DE SÃO PAULO. .51

FIGURA 29 - MAPA TEMÁTICO ILUSTRANDO AS DIFERENÇAS ENTRE OS TRAÇADOS PARA A ZCI ADOTADA NESTE TRABALHO (CPRM 2006) E ESTUdOS ANTERIORES. A) TEIXEIRA (2000) E HIRUMA (1999); B) IPT (1981); C) PRóMINÉRIO/SIICT (1988) E GEOLOGIA DA REGIÃO ADMINISTRATIVA 3 (1977); D) DAEE/UNESP (1984) E EMPLASA (1980). OS RETÂNGULOS ALFABETICAMENTE IDENTIFICADOS REFEREM-SE AOS DETALHES NO MAPA REGIONAL, ... ERRO! INDICADOR NÃO DEFINIDO.

FIGURA 30-MAPA DE RELEVO SOMBREADO COM DESTAQUE PARA A ZCI. OS ILUMINANTES ESTÄO POSICIONADOS EM NORTE ESUL, RESPECTIVAMENTE, COM $30^{\circ}$ OE ELEVAÇÃO. 55

FIGURA 31 - MAPA dE RELEVO SOMBREAdO COM DESTAQUE PARA A ZCI. OS ILUMINANTES ESTÃO POSICIONADOS EM NOROESTE E SUDESTE, RESPECTIVAMENTE, COM $30^{\circ}$ DE ELEVAÇÄO. 56

FIGURA 32 - COLUNA LITOESTRATIGRÁFICA ESQUEMÁTICA DA SEÇÃO PALEOZÓICA DA BACIA DO PARANA. EXTRAIDO DE GESICKI ET AL. (2002), MODIFICADO DE FRANÇA \& POTTER (1988) E MATOS (1995). 58

FIGURA 33 - INDICAÇÃO DO CAMPO DE ESFORÇOS PARA AS ESTRUTURAS OBSERVADAS EM CERQUILHO, SP. QUADRADOS BRANCOS E PRETOS SÄO REFERENTES A PÓLOS E EIXOS DE DOBRAS DE ARRASTO, RESPECTIVAMENTE; TRIÂNGULOS BRANCOS E PRETOS SÃO POLLOS E EIXOS DE DOBRAS ANTICLINAIS, RESPECTIVAMENTE. EXTRAIDO DE ROCHA CAMPOS ET AL. (2000)

FIGURA 34 - COMPILAÇÃO COM AS PRINCIPAIS LOCALIDADES E SENTIDOS DE SUPERFICIES DE ABRASÄO NA BACIA DO PARANÁ. EXTRAIDO DE GESICKI ET AL. (2002), MODIFICADO DE RICCOMINI \& VELAZZUUZ (1999).

FIGURA 35 - HIERARQUIZAÇÃO DE FAMILIAS DE FALHAS POR RELAÇÃO DE CORTE EM AFLORAMENTO. AS FALHAS MAIS REPRESENTATIVAS ESTÃO SIMBOLIZADAS POR CORES. A PRIMEIRA GERACÃO CORRESPONDE A UINHA VERMELHA, A SEGUNDA ÀS LINHAS AZUIS, A TERCEIRA AS LINHAS VERDES, A QUARTA À LINHA ROXA E A QUINTA GERAÇÃO PELA LINHA ALARANJADA

FIGURA 36 - DETERMINAÇÃO DO CAMPO DE ESFORÇOS PARA AS QUATRO PRIMEIRAS FAMILIAS DE FRATURAS HIERARQUIZADAS NO GRUPO ITARARÉ. NOTAR 51 (CAMPO EM VERMELHO) CONSTANTEMENTE VERTICAL E ROTAÇÃO HORÁRIA DE $\Sigma 2$ E $\Sigma 3$ (CAMPOEM AZUL). 64

FIGURA 37 - DETERMINAÇÃO DO CAMPO DE ESFORÇOS COMPRESSIVOS QUE CONDICIONOU A SUPERFICIE DE DESCOLAMENTO, DOBRASE FALHAS INVERSAS, INOICANDO TRANSPORTE PARA SE.

FIGURA 38 - ESTRUTURAS QUE EVIDENCIAM O SENTIDO DE TRANSPORTE (SETA VERMELHA) DO PACOTE SUPERIOR DE ROCHAS SEDIMENTARES DO GRUPO ITARARE: A) SEPARACÃO DOS PACOTES / E /I PELA SUPERFICIE DE DESCOLAMENTO DESTACADA PELA LINHA TRACEJADA VERMELHA; B) DOBRA RESULTANTE DA DEFORMAÇÃO CAUSADA PELO TRANSPORTE COM PLANO AXIAL E EIXO MARCADO PELA LINHA TRACEJADA VERMELHA; C) FALHA INVERSA COM INDICADORES CINEMATICOS FORMADOS POR DEGRAUS DE CRESCIMENTO MINERAL. 
FIGURA 39 - DETERMINAÇÃO DO CAMPO DE ESFORÇOS PARA A FALHA QUE CONDICIONA A FRENTE DO AFLORAMENTO E É A MAIS JOVEM DAS DEFORMAÇÕES ESTUDADAS NO LOCAL. A CINEMÁTICA É TRANSCORRENTE SINISTRAL COM COMPONENTE NORMAL.

FIGURA 40 - MAPA geOLÓGICO ESQUEMATICO COM A LOCALIZAÇAO DA PROVINCIA GRANITICA ITU. 1) ROCHAS SEDIMENTARES PALEOZOICAS E ROCHAS VULCÂNICAS INOIFERENCIADAS (BACIA DO PARANA); 2) GRANITOIDES DA PROVINCIA MAGMATICA ITU (590-580 MA). EXTRAIDO de JANASI ET AL. (2009), MODIFICADO de GaLEMBECK (1997). 68

FIGURA 41 - MAPA ESQUEMÁTICO DO BATÓITO ITU. MODIFICADO DE GALEMBECK (1991). 69

FIGURA 42 - DETERMINAÇÃO DO CAMPO DE ESFORÇOS PARA FALHAS TRANSCORRENTES DESTRAIS E SINISTRAIS, RESUITANTES DOS ESFORÇOS COMPRESSIVOS MÁXIMO II NNE-SSW E MINIMO 33 WNW-ESE. 71

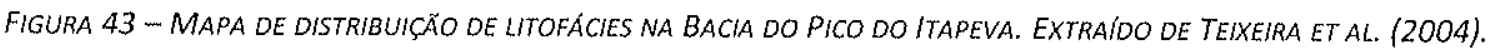

FIGURA 44 - DIAGRAMA de DENSIDAdE DE PÓLOS. A) ACAMAMENTO RELIQUIAR (SO) E ATITUdE MÉDIA DAS MEDIDAS; B) FOLIAÇÃO METAMORFICA (S1) E ATITUDE MÉDIA DAS MEDIDAS. EXTRAIDO DE TEIXEIRA 2000. .75

FIGURA 45 - DIAGRAMA COM DISTRIBUIÇÄO DOS PÓLOS DO ACAMAMENTO RELIQUIAR SO, SEGUNDO A DIREÇÃO NE-SW, COMMERGULHOS PARA SE, OBTIDOS NA BACIA DO PICO DO ITAPEVA. .76

FIGURA 46 - DIAGRAMA COM DISTRIBUIÇÃO DOS PÓLOS DAS FOLIAÇOESS (SC) E LINEAÇOES (LC) DE CISALHAMENTO OBTIDOS NA BACIA DO PICO DO ITAPEVA, DEMONSTRANDO ESFORÇOS COMPRESSIVOS DE DIREÇÃO NW-SE. .77

FIGURA 47-QUADRO DE RELAÇÃO ENTRE A SEDIMENTAÇÃO QUATERNARIA E A NEOTECTÓNICA NO PLANALTO DE CAMPOS DO JORDÃO. EXTRAIDO DE HIRUMA ET AL. (2001). .79

FIGURA 48 - FALHAS DE COMPONENTE TRANSCORRENTE SINISTRAL DE ORIENTAÇÃO NNE-SSW EMBUTINDO TECTONICAMENTE COLÚVIOS (C1 A C4) E HORIZONTES DE PALEOSSOLOS (P1 A P4) PLEISTOCENICOS, EM GNAISSES MILONITIZADOS DA ZCI.

FIGURA 49 - DETERMINAÇÃO DO CAMPO DE ESFORÇOS PARA FALHAS DE DIREÇÄO NNE E COMPONENTES SINISTRAIS QUE AFETAM OS DEPÓSITOS COLUVIAIS E PALEOSSOLOS PLEISTOCENOS, RESULTANTES DE ESFORÇOS COM II NW-SE E 23 NE-SW.

FIGURA 50 - MAPA HIPSOMÉTRICO NA REGIÄO DO PLANALTO DE CAMPOS DO JORDÃO COM DIAGRAMAS POLARES DE JUNTAS DE CISALHAMENTO AO LONGO DA ZCI. ERRO! INDICADOR NÃO DEFINIDO.

FIGURA 51- ESBOÇO GEOLÓGICO dO MACIÇO ALCALINO DE PASSA QUATRO. EXTRAIDO DE CHIESSI (2004). 85

FIGURA 52 - SEGMENTO ORIENTAL dO ALINHAMENTO MAGMÁtICO DE CABO FRIO. DISTRIBUIÇÃO de CORPOS ALCALINOS MESOZOICO-CENOZOICOS CONTROLADOS POR COMPRESSÃO NE-SW NA PORÇÃO CENTRO-LESTE DO ESTADO DO RIO DE JANEIRO E A INDICAÇÃO DO BINARIO TRANSCORRENTE SINISTRAL WNW-ESE. EXTRAIDO DE RICCOMINI ET AL. (2005).

FIGURA 53 - GRAFICO DE ROSETA E HISTOGRAMA REPRESENTANDO AS DIREÇÓES PARA TODOS OS DIQUES DO MACIÇO ALCALINO DE PASSA QUATRO.

FIGURA 54 - DIAGRAMAS ROSETAS E HISTOGRAMAS REFERENTES ÀS PRINCIPAIS FREQUËNCIAS NAS DIREÇÓES DE ORIENTAÇÃO DOS DIQUES: A) NEFELINA MICROSSIENITO; B) FONOLITO; E C) LAMPROFIRO. 


\section{INTRODUÇÃO E OBJETIVOS}

O embasamento pré-cambriano do sudeste do Brasil é recortado por zonas de cisalhamento de caráter dúctil, de orientação geral ENE-WSW, ativas durante o Neoproterozoico ao início do Fanerozoico (Sadowski \& Campanha 2004). No Estado de São Paulo, estudos recentes têm demonstrado a existência de reativações sucessivas de algumas dessas zonas de cisalhamento (Sadowski 1993, Garcia \& Campos Neto 1997, Teixeira 2000, Almeida et al. 2010), no entanto, com caráter rúptil desde o Neopaleozoico ( v.g. Riccomini 1995).

Evidências de múltiplas reativações fanerozoicas, especialmente no Mesozóico-Cenozóico, podem ser reconhecidas a partir de deformações impostas por estas zonas de cisalhamento no registro sedimentar, presente não somente nas áreas geográficas das bacias do Paraná, São Paulo e Taubaté, como também nas áreas de ocorrência de rochas do embasamento pré-cambriano e corpos intrusivos mais jovens (Riccomini 1989, Salvador \& Riccomini 1995, Riccomini \& Assumpção 1999, Hiruma et al. 2001, ModenesiGautieri et al. 2002, Chiessi 2004).

A provável relação das reativações tectônicas mais recentes com ocorrência de abalos sísmicos tem despertado o interesse da comunidade geocientifica e órgãos governamentais da área de energia, uma vez que eventos dessa natureza podem ocorrer mesmo em porções da crosta continental intraplaca, admitidas como estáveis até poucas décadas atrás.

A ocorrência de registros de atividade neotectônica, bem como de abalos em zonas sismogênicas, principalmente no sudeste do Brasil, tornam necessário o entendimento de tensões crustais, essenciais para a implantação de obras de engenharia de grande porte, tais como: centrais nucleares, gasodutos, túneis e usinas hidrelétricas (Hasui et al. 1978 a, Hasui et al. 1982, Riccomini \& Assumpção 1999). O retrabalhamento e a dinâmica causada por mudanças na magnitude de campos de esforços contemporâneos permitem avaliar a permeabilidade de zonas de cisalhamento, o que implica na avaliação do fluxo de fluídos em subsuperficie, fator de extrema importância na indústria do petróleo e no comportamento de águas subterrâneas (Caine et al. 2009). 
Embora esses registros de reativações sejam numerosos, há uma carência de informações que caracterizam a distribuição e comportamento de estruturas resultantes desse processo ao longo de grandes zonas de cisalhamento preexistentes.

No presente trabalho buscou-se compreender essas caracteristicas e analisar diferentes campos de esforços atuantes ao longo da história geológica dessas feições. Para tanto foi selecionada como alvo de estudo a Zona de Cisalhamento Jundiuvira (Hasui et al. 1969), cujo traçado pode ser reconhecido desde as imediações de Itu, onde é recoberta pelos depósitos sedimentares da Bacia do Paraná, passando pela região de Sapucaí Mirim, no estado de Minas Gerais (Cavalcante et al. 1979), rumo às proximidades de Passa Quatro (Hasui et al. 1978 b). Essa grande falha, com extensão reconhecida de pouco menos de $300 \mathrm{~km}$, é uma feição tectônica suavemente curviplanar, de direção média ENE. Possui grande importância na compartimentação do embasamento précambriano do sudeste brasileiro, nivelando blocos ou terrenos com naturezas crustais diferentes.

Observada em escala regional, a Zona de Cisalhamento Jundiuvira (ZCJ) apresenta traçado subparalelo à linha-de-costa, um padrão paralelo a grandes feições geológicas e geomorfológicas regionais, tais como as Serras do Mar e da Mantiqueira, além do Rift Continental do Sudeste do Brasil. Parece ainda controlar o traçado do rio Tietê, nas proximidades de Jundiaí, e a escarpa da Serra da Mantiqueira, nas vizinhanças de Campos do Jordão (Neves 2005, Hiruma 1999).

A presente dissertação teve como objetivo compreender e caracterizar o traçado e os diferentes campos de esforços ao longo da ZCJ, auxiliado por resultados obtidos em análises morfométricas, dados estruturais coletados em levantamentos de campo e reinterpretações de dados extraídos da bibliografia. Os resultados foram, então, confrontados com os estudos realizados anteriormente, avaliando a sua concordância ou mesmo divergência entre os modelos geológico-estruturais propostos. 


\section{LOCALIZAÇÃO DA ÁREA DE ESTUDO}

De modo a se atingir os objetivos propostos, foram selecionadas três áreas de estudo, em função da presença de rochas de diferentes idades que poderiam ser empregadas como marcadores cronológicos dos diferentes eventos de reativação ao longo da ZCJ: arredores de Itu, Planalto de Campos do Jordão e Maciço Alcalino de Passa Quatro (figura 1). Nessas áreas foram realizados levantamentos de campo e/ou compilação de dados preexistentes.Nos arredores de Itu, SP, foram estudados depósitos sedimentares falhados do Grupo Itararé, expostos em olaria situada a cerca de $4 \mathrm{~km}$ a oeste do centro da cidade. Na mesma região foram analisados dados de falhas em rochas do Granito de $1 \mathrm{tu}$, obtidos previamente pelo orientador deste trabalho a aproximadamente $10 \mathrm{~km}$ a leste do centro da cidade, no sentido de Jundiai, e que integram o banco de dados estruturais do Laboratório de Neotectônica, Departamento de Geologia Sedimentar e Ambiental, Instituto de Geociências, Universidade de São Paulo.

$\mathrm{Na}$ região do Planalto de Campos do Jordão foram examinadas exposições de rochas metassedimentares ediacaranas da Formação Pico de Pico de Itapeva, da bacia homônima, rochas pré-cambrianas de seu embasamento, e depósitos sedimentares quaternários que os cobrem. Estas exposições estão situadas na região do mirante do Pico do Itapeva, aproximadamente $5 \mathrm{~km}$ a sudeste da cidade. Para esta área foram também empregados dados da literatura (Juliani et al. 1990, Riccomini 1993, Hiruma 1999, Teixeira et a./ 2000) e dados obtidos pelo orientador e hoje arquivados no banco de dados estruturais do laboratório de Neotectônica do IGc-USP.

Os dados obtidos para a porção do extremo nordeste da estrutura foram extraídos da literatura (Chiessi 2004), na região do Maciço de Passa Quatro, também conhecida como Serra Fina. 


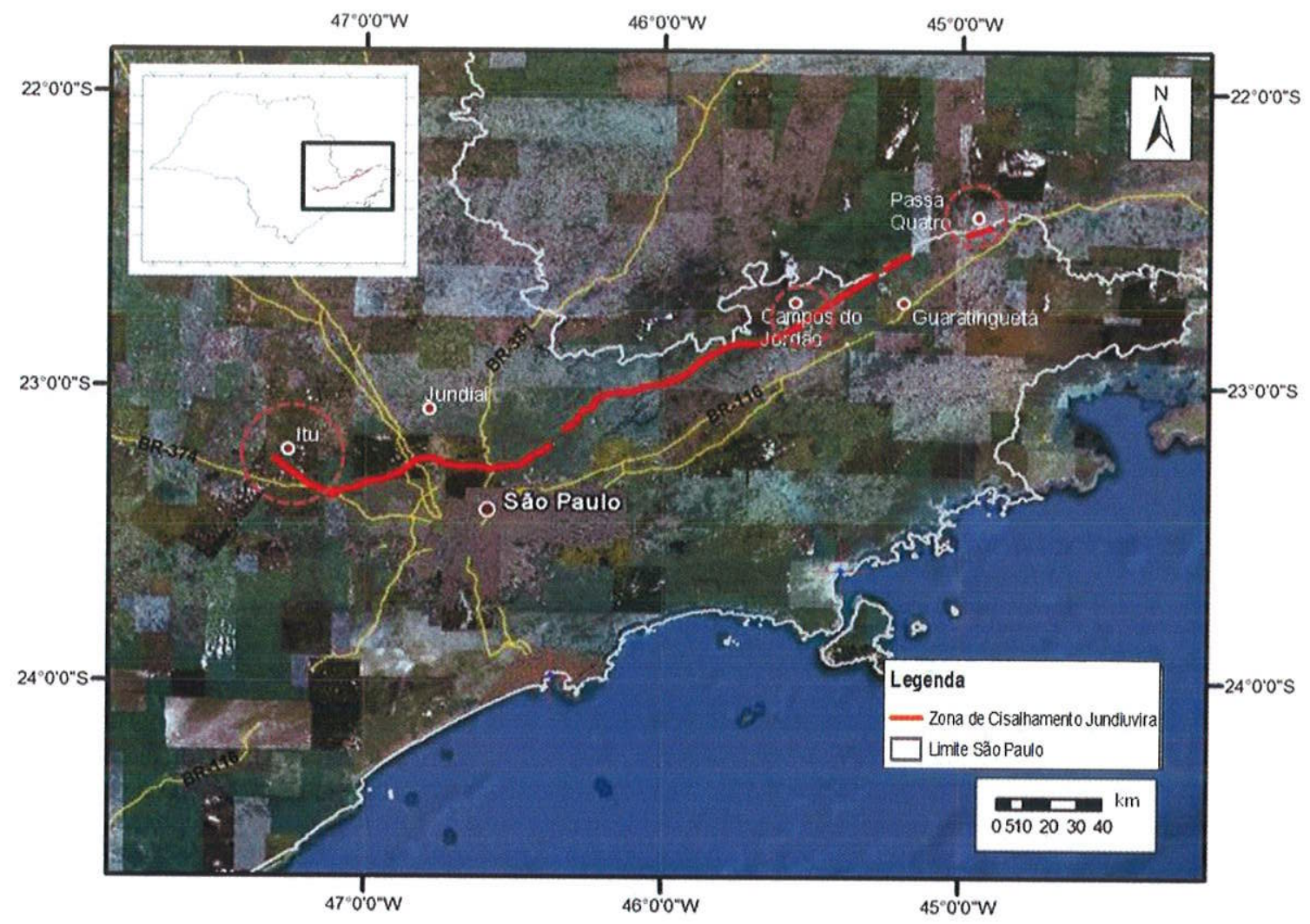

Figura 1 - Mapa esquemático com a localização da ZCJ e as áreas estudadas. 


\section{MATERIAIS E MÉTODOS}

\subsection{MATERIAIS}

Para a execução deste estudo foram utilizados equipamentos básicos de campo, tais como bússola, martelo geológico, câmera fotográfica, GPS, mapas de localização, caderneta de campo, entre outros. Foram também empregados dados topográficos do Shuttle Radar Topography Mission (SRTM), documentos cartográficos disponiveis (mapas topográficos, geológicos e geomorfológicos) e programas computacionais para tratamento de dados espaciais e estruturais.

Os dados SRTM, em formato GEOTIFF, resolução espacial de $90 \mathrm{~m}$ e datum WGS84, foram obtidos no sitio da EMBRAPA/Brasil em Relevo (2011) e correspondem às seguintes folhas: SF-23-Y-A, SF-23-Y-B, SF-23-Y-C, SF-23Y-D, SF-23-Z-A e SF-23-Z-B.

As cartas topográficas empregadas correspondem às folhas Guaratinguetá (SF-23-Y-B) e Santos (SF-23-Y-D), ambas na escala 1:250.000.

Os mapas geológicos empregados foram os seguintes:

i) Mapa Geológico do Estado de São Paulo, escala 1:750.000 (CPRM 2006);

ii) Mapa Geológico do Estado de São Paulo, escala 1:500.000 (IPT 1981);

iii) Mapa Geológico do Estado de São Paulo, escala 1:250.000: , Folha São Paulo (UNESP \& DAEE 1984);

iv) Folhas da carta geológica da Região Metropolitana de São Paulo, escala 1:50.000 (EMPLASA 1980): 34_Guarulhos (SF23-Y-C-III-4) e 44_Itaquaquecetuba (SF-23-Y-D-I-3);

v) Mapa Geológico da Geologia da Região Administrativa 3, escala 1:100.000 (IPT 1977: folhas SF-23-Y-B-1, SF-23-Y-B-4, SF-23Y-B-5 e SF-23-Y-B-6;

vi) Mapa Geológico do Programa de Desenvolvimento de Recursos Minerais (Pró-Minério), escala 1:50.000 (SIICT/Pró-Minério 
1988): folhas Igaratá, Piracaia, Monteiro Lobato e Camanducaia;

Folha Igaratá - SF-23-Y-D-I-2;

Folha Piracaia - SF-23-Y-D-I-1;

Folha Monteiro Lobato - SF-23-Y-B-V-3;

Folha Camanducaia - SF-23-Y-B-IV-4;

vii) Esboço Geológico do Maciço Alcalino de Passa Quatro (escala gráfica indicada no mapa) (Chiessi 2004);

viii) Pico do Itapeva - Distribuição de litofácies (escala gráfica indica no mapa) (Teixeira 2000);

Além desses documentos, foram empregados os mapas morfotectônico do frontão sudeste do Planalto de Campos do Jordão, escala 1:25.000, e mapa de fotolineamentos (escala gráfica indicada no mapa), elaborados por Hiruma (1999).

Os programas computacionais empregados foram o Openstereo $0.1 .2 \mathrm{~d}$ (Grohmann \& Campanha 2010), T-Tecto 3.0 (Žalohar, J. \& Vrabec, M., 2007), ArcMap/ArcGis 9.3 - ERSRI, Corel Photo-Paint 12 e Corel 12 (Corel Corporation).

\subsection{MÉTODOS}

\subsubsection{VETORIZAÇÃO DE CARTAS TOPOGRÁFICAS, GEOLÓGICAS E DADOS DE TRABALHOS ANTERIORES}

Com o objetivo de caracterizar os traçados interpretados por diferentes autores para a ZCJ, mapas geológico-estruturais de diferentes estudos foram escanerizados e armazenados em um banco de dados. Posteriormente, com o auxillo de um software de edição e processamento geoespacial, essas cartas 
foram georreferenciadas de acordo com suas respectivas coordenadas e datuns geodésicos.

Grande parte dos dados obtidos é oriunda de trabalhos antigos elaborados com diferentes técnicas, portanto sujeitas a imprecisões locacionais às quais se somam as deformações inerentes ao processo de cópia e escanerização. Visando minimizar estes aspectos, foram utilizadas como base, cartas topográficas vetorizadas obtidas na website do Instituto Brasileiro de Geografia e Estatística - IBGE. Dessa forma, feições naturais notáveis ou grandes obras de engenharia que, provavelmente, não sofreram grandes alterações ao longo do tempo, serviram como pontos de amarração para as cartas utilizadas, procurando-se assim minimizar o acúmulo de erros de deslocamentos e deformações no georreferenciamento.

\subsubsection{MODELO DIGITAL DE ELEVAÇÃO}

Os modelos digitais de elevação (MDE) consistem de uma malha georreferenciada de pontos contendo a elevação do terreno em cada ponto. Estes pontos podem ser observados na forma de mapas que são geralmente associados a uma escala gradual de cores que representam as elevações ou como de imagens tridimensionais. Os modelos tridimensionais apresentam uma visão semi-realística do relevo e podem ser rotacionados ao longo dos eixos de coordenadas, permitindo observar diversos panoramas do terreno. A possibilidade de se utilizar uma iluminação artificial disposta em azimutes e ângulos diferentes permite ressaltar feições relevantes da área estudada e a sua caracterização.

O MDE da área estudada foi elaborado a partir da base de dados SRTM (Shuttle Radar Topographic Mission) com resolução espacial de 3arcsec $(\sim 90 \mathrm{~m})$. O projeto SRTM consistiu de um levantamento realizado em cooperação entre a National Aeronautics and Space Agency (NASA), o Centro Espacial Alemão (DLR) e a Agência Espacial Italiana (ASI), com o objetivo de rastrear a superfície do planeta obtendo dados precisos de altimetria. A aquisição das informações altimétricas se baseia na interferometria de radar entre dados obtidos de um mesmo ponto na superfície, a partir de duas posições diferentes. 
O MDE de detalhe da área de estudo foi obtido através de técnicas de geoprocessamento aplicadas à topografia de detalhe da área (varredura a laser).

\subsubsection{MORFOMETRIA}

A morfometria ou geomorfometria consiste na caracterização essencialmente quantitativa das formas de terreno, com base na obtenção de diferentes parâmetros numéricos, baseados em dados topográficos e da rede de drenagens. Os parâmetros podem representar tamanho, direção, inclinações, elevação, razões de área, densidades relativas etc., a partir dos quais podem ser elaborados mapas, modelos tridimensionais, perfis e análises estatísticas.

A análise de parâmetros e mapas morfométricos permite identificar diferentes padrões morfométricos e caracterizar distintas formas de relevo. $O$ tratamento estatístico dos dados permite uma avaliação da área como um todo, enquanto que os mapas permitem analisar a variação espacial destes parâmetros na região estudada.

A análise morfométrica representa uma ferramenta ágil para caracterização de uma área estuda e na maioria dos casos antecede os levantamentos de campo. A técnica auxilia nos levantamentos geológicos, incluindo trabalhos de mapeamentos básicos, pois muitas vezes as formas de relevo são condicionadas pelos diferentes tipos de rochas aflorantes em uma determinada região. Contudo, é no estudo tectônico que a análise morfométrica tem se demonstrado uma ferramenta poderosa. Sabe-se que as formas de relevo encontram-se geralmente submetidas a um controle tectônico que condiciona o padrão geomorfológico e as redes de drenagem (Summerfield 1993, Stewart \& Hancock 1994). Feições típicas identificáveis na paisagem incluem: deflexões, deslocamento e capturas de drenagens, escarpas, alinhamentos de vales, soerguimentos e arqueamentos, como exemplificados na figura 2.

Na realização desta pesquisa, foi obtido o parâmetro morfométrico de hipsometria. 


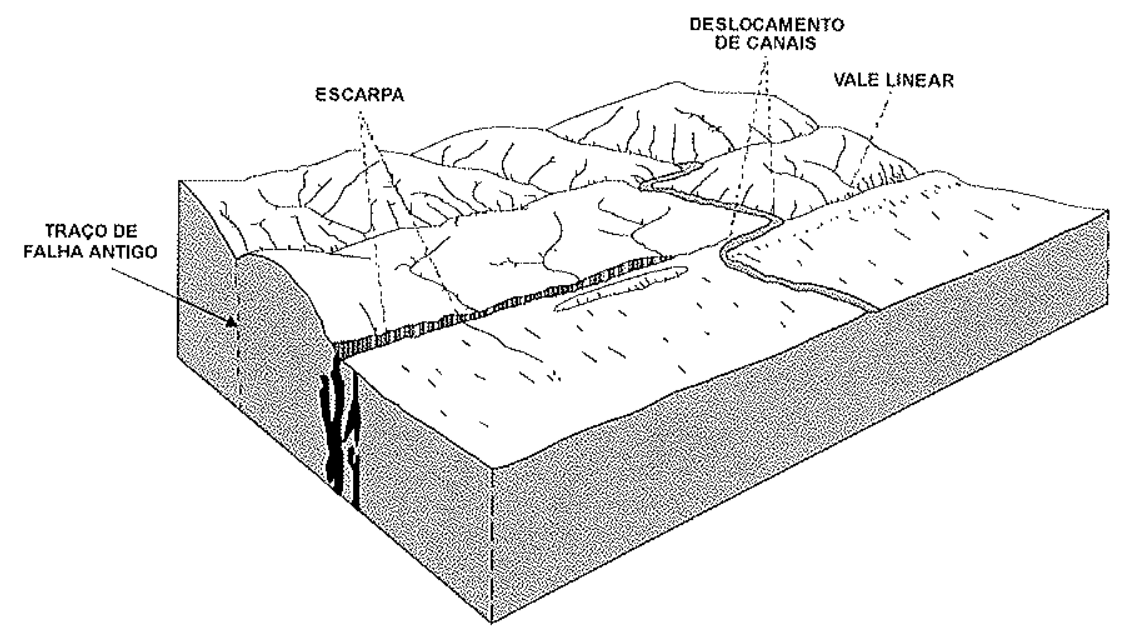

Figura 2 - Feições de relevo associadas à movimentação tectônica (modificado de Summerfield 1993).

O mapa hipsométrico consiste na classificação altimétrica do relevo, sendo obtido diretamente do MDE. As classes foram definidas com base na variação topográfica apresentada pela área.

\subsubsection{MAPAS DE RELEVO SOMBREADO}

Os mapas de relevo sombreado consistem de imagens geradas a partir do MDE, que simulam a iluminação artificial do terreno a partir de um ponto escolhido no espaço (azimute e inclinação). O resultado é uma imagem onde as porções de relevo voltadas diretamente para o iluminante aparecem em tonalidades mais claras e as porções escondidas pelos altos do relevo em tonalidades mais escuras, de forma que as feições geomorfológicas marcantes como vales, cristas e escarpas são destacas (figura 3 ).

A possibilidade de escolha na posição do iluminante permite ressaltar feições orientadas em diferentes direções, constituindo uma ferramenta poderosa na extração de lineamentos e demais caracteristicas relevantes para estudos geológicos. 

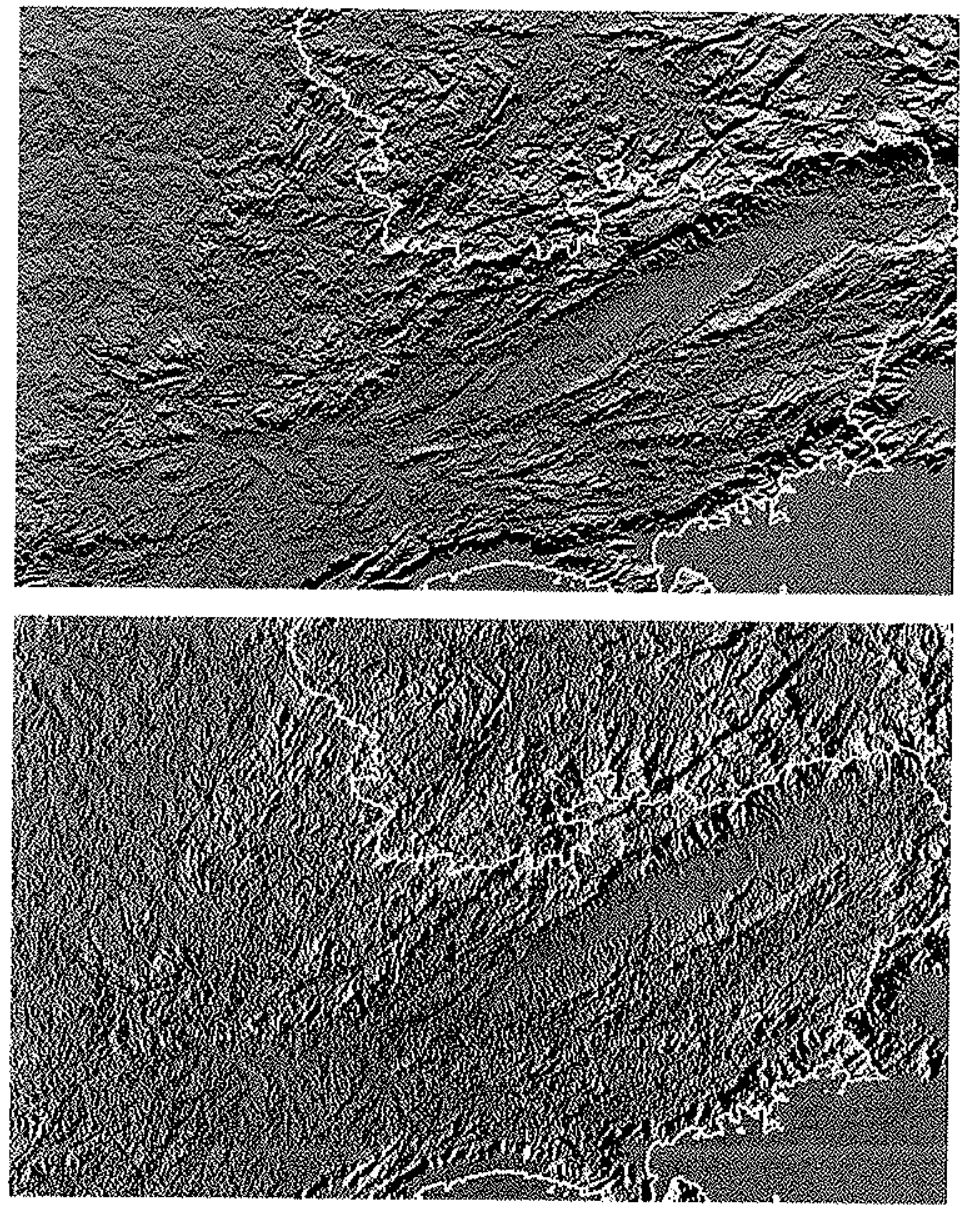

Figura 3 - Mapas de relevo sombreado, onde os iluminantes estão posicionados em Norte (acima) e Oeste (abaixo). Em azul está repres

entado o traçado da ZCJ.

\subsubsection{TRABALHOS DE CAMPO}

Os levantamentos de campo consistiram na inspeção de afloramentos nas áreas visitadas, observando-se feições geomorfológicas, estratigrafia, litotipos presentes e estruturas rúpteis.

Baseado nesses conhecimentos procurou-se hierarquizar as estruturas presentes com relações de corte, tomando-se medidas estruturais e as relações com indicadores cinemáticos, muitas vezes presentes como relação falha-estria.

Posteriormente essas medidas foram tabeladas e tratadas em software de análises estruturais específicos. 


\subsubsection{ANÁLISE DE DADOS ESTRUTURAIS}

A análise de dados estruturais em mesoescala foi o método mais importante para a determinação e caracterização de paleotensões neste trabalho. Essa análise envolveu a observação de feições estruturais rúpteis deformadoras das rochas nas adjacências da ZCJ.

O ambiente geológico nas relações estratigráficas entre os diferentes niveis de litotipos, intrusões de rochas magmáticas formadoras de diques (aproveitando conhecimentos anteriores sobre a idade das rochas), juntas ou famílias de juntas, e as relações entre planos falhas e indicadores cinemáticos, serviram para qualificar e quantificar antigos esforços, sentidos de transporte e idades relativas dos eventos.

Foram caracterizadas as distribuições espaciais das feições citadas, tratando estes dados em diferentes softwares que utilizam métodos consagrados na literatura, obtendo-se, dessa forma, a direção dos esforços vigentes durante a formação e/ou reativação dessas estruturas.

A utilização de estruturas planares, juntas e falhas, foram caracterizadas de acordo com suas atitudes. Esses dados foram inseridos no programa T-Tecto 3.0 (Žalohar, J. \& Vrabec, M., 2007) que determina os três principais eixos de tensões, ortogonais entre si, e são correspondentes à compressão máxima, intermediária e mínima, denominadas respectivamente de $\sigma_{1}, \sigma_{2}$ e $\sigma_{3}$.

Hancock (1985) e Dunne \& Hancock (1994) definiram relações geométricas entre a posição desses esforços e juntas. Essas feições representam planos ortogonais ao tensor de menor esforço $\left(\sigma_{3}\right)$, bem como, na bissetriz aguda de um grupo, representadas por um conjunto ou uma família de juntas.

Em determinados casos, fraturas limitam blocos que apresentaram movimentações relativas entre eles, caracterizando falhas. Quando são observáveis indicadores cinemáticos rúpteis, seja por deslocamentos de marcadores estratigráficos, seja pela presença de feições lineares assimétricas contidas nas superfícies dessas estruturas, têm-se dados pareados entre planos e estrias, nos quais estas últimas representam a componente cisalhante do esforço sobre o plano, e nesses casos são passíveis de determinação as 
suas relações geométricas com os eixos de esforços responsáveis por esses deslocamentos.

Com base no princípio que uma falha ou família foi gerada em um mesmo episódio tectônico, que produziu movimentações resultantes de um estado de tensões médio, são determináveis os eixos de esforços vigentes.

No método de Angelier \& Mechler (1977), denominado método dos diedros retos, podem ser determinados campos de tensões para as estruturas analisadas. Para cada plano de falha e respectiva estria é determinado um plano auxiliar, ortogonal ao plano e as estrias nele contidas. O conjunto de dados reais pareados (plano/estria) e plano auxiliar definem espacialmente quatro diedros, dois opostos distensivos $\left(\sigma_{3}\right)$ e dois opostos compressivos $\left(\sigma_{1}\right)$. O mesmo procedimento, repetido para diferentes falhas já hierarquizadas por relações de corte ou estratigráficas, tem seus resultados sobrepostos, observando-se áreas coincidentes dos diedros.

A figura 4 ilustra a construção de um plano auxiliar perpendicular ao plano/estria da falha (a), determinando, de acordo com a cinemática observada na estrutura, os diedros compressivos e distensivos (b). A sobreposição dos dados gera um diagrama com diedros compativeis nos domínios de esforços (c). 
I)

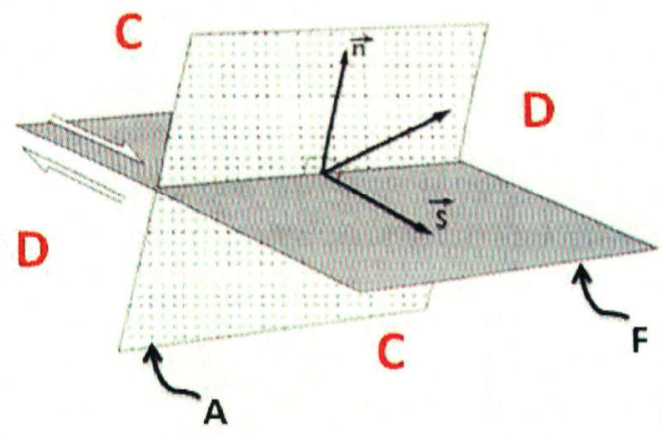

III)

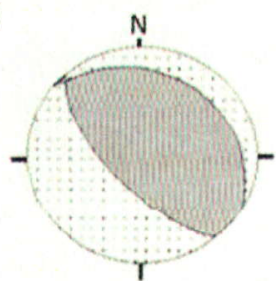

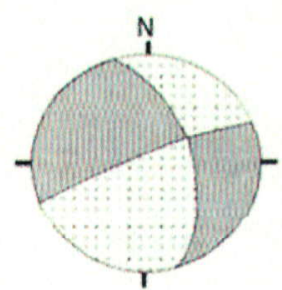
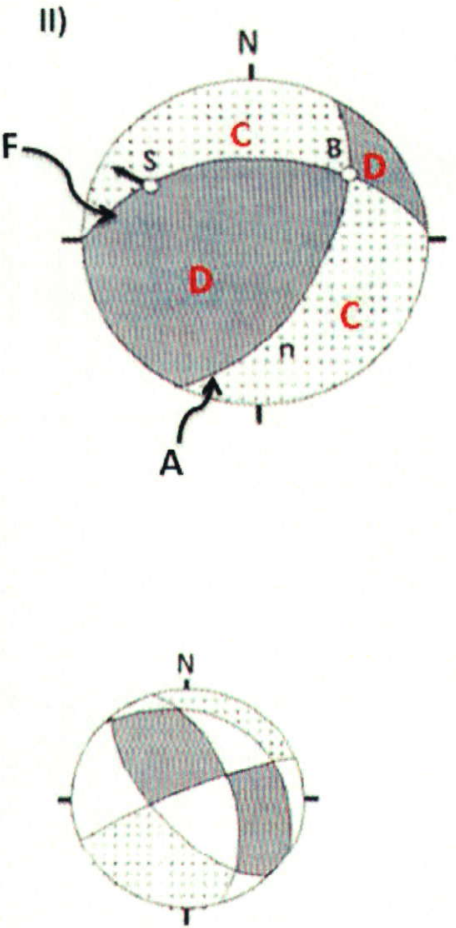

Figura 4 - Método dos diedros retos. I) Falha ( $F$ ) e plano auxiliar (A) delimitando diedros compressivos (C) e distensivos (D). A direção e o sentido de movimento da falha estão representados pelo vetor unitário de movimento $(s)$ e vetor unitário ortogonal à falha (n); (II) Projeção estereográfica dos planos $F$ e $A$, onde $B$ é a intersecção dos dois, $C$ é o diedro compressivo e $D$ o distensivo. III) os dois primeiros diagramas representam uma falha normal e outra direcional; o terceiro é a superposição de ambos. As áreas em cinza representam $100 \%$ de compressão, as áreas pontilhadas $100 \%$ de distensão e branco são domínios onde ocorre compressão e distensão. Extraído de Angelier (1994).

Por fim, foram utilizados dados de diques, que, como será discutido adiante, servem com indicadores cinemáticos, pois possuem direção ortogonal ao vetor de menor esforço compressivo.

As direções dessas feições foram extraídas segundo sua composição litológica, determinando-se assim as direções principais para cada grupo e para todos os diques. Essas direções preferenciais foram representadas em diagramas de rosetas e histogramas empregando-se o programa Openstereo 0.1.2d (Grohmann \& Campanha 2010). Os diagramas são a representação gráfica das distribuições de frequência das direções dos diques. Os 
histogramas são representados por barras verticais separados em intervalos de $10^{\circ}$ no eixo das abscissas e acúmulo de frequências no eixo das ordenadas. Diagramas de roseta possuem características semelhantes, porém as barras de frequências são dadas no formato de pétalas que refletem medidas no intervalo de $0^{\circ}$ a $180^{\circ}$.

\section{JUNTAS E FALHAS COMO INDICADORES DE ESFORÇOS TECTONNICOS}

O termo junta refere-se a uma fratura que em mesoescala, ou seja, em escala de afloramento, caracteriza uma fratura sem preenchimento e indicios de movimentação relativa ao bloco adjacente (Hancock 1985, Dunne \& Hancock 1994). As juntas normalmente apresentam superficies irregulares, com pequena continuidade, raramente ocorrendo de maneira isolada, apresentando uma pequena dispersão angular, menor do que $10^{\circ}$, que quando ultrapassada caracteriza a existência de mais de uma família de juntas (Dunne \& Hancock 1994).

Juntas se mostram como bons indicadores de campos esforços vigentes durante sua formação, conforme demonstrado por muitos autores (Hancock 1985, Dunne \& Hancock 1994, Caputo 1995, Chiessi 2004). Inicialmente, antes da determinação do campo de esforços, é necessária a caracterização da sequência relativa da formação das diferentes familias de juntas, definidas conforme sua relação de corte (Dunne \& Hancock 1994) (figura 5).

A

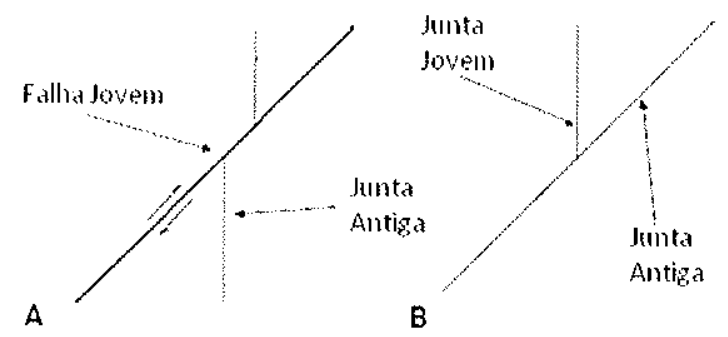

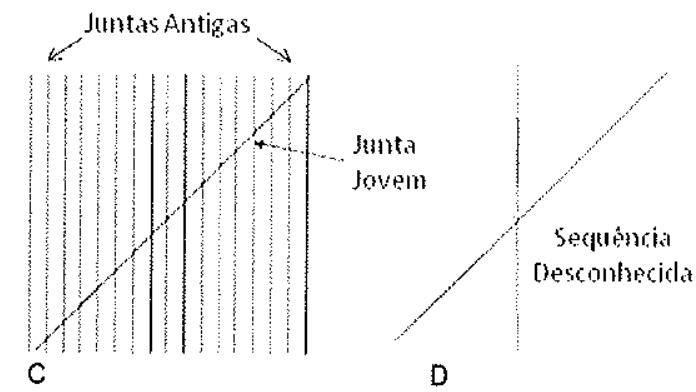

c
Figura 5 - Criterio para determinação de relação cronológica entre diferentes famílias de juntas. (a) Junta pretérita deslocada por falha; (b) Junta mais jovem com terminação em junta antiga; (c) Juntas antigas cortadas por junta jovem de atitude diferente; (d) sucessão cronológica indefinida apenas pela relação de corte entre diferentes juntas. Extraido de Dunne \& Hancock (1994). 
Juntas podem ser classificadas por sua geometria e arquitetura, separadas em três classes. A primeira trata de juntas sistemáticas, com geometria planar ou subplanar, penetrativas, lineares em planta e com origem relacionada a campos de esforços em ambiente tectônicos profundos. As juntas não sistemáticas, pertencentes á segunda classe, não possuem grande continuidade, são descontínuas e irregulares, com ocorrência mais restrita e origem ligada a ambientes superficiais. Quando esta segunda classe ocorre ortogonalmente a juntas sistemáticas, esse sistema é denominado cross-joint (figura 6).

Ocasionalmente, sistemas de mais de uma familia de juntas podem ocorrer contemporaneamente, gerados a partir de um mesmo regime de esforços, caracterizando a classe conhecida como juntas conjugadas.

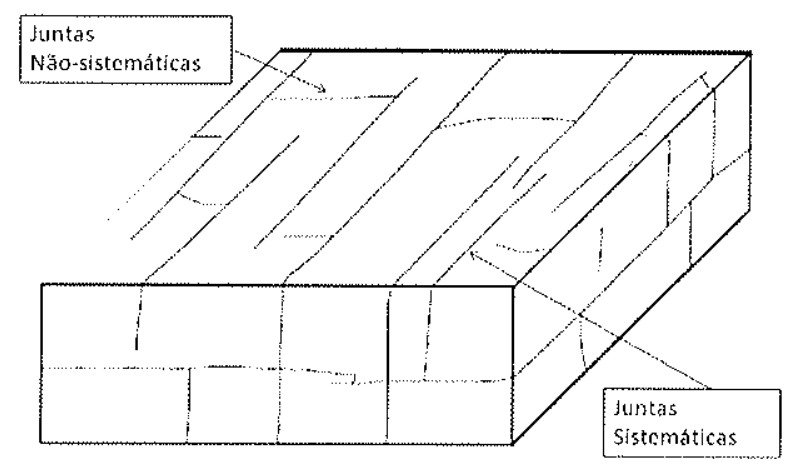

Figura 6 - Classificação geométrica de juntas. Extraido de Dunne \& Hancock (1994).

Segundo Angelier (1984), duas familias de fraturas podem ser consideradas conjugadas quando são contemporâneas e foram originadas no mesmo campo de esforços. Além disso, elas devem ter sido formadas em ambiente rúptil, em um corpo de rocha mecanicamente intacto, e propagaramse ao longo de planos cujas orientações são compatíveis com os critérios de ruptura de Mohr-Coulomb.

Utilizando-se dos critérios de Mohr é possivel determinar que juntas de distensão são formadas quando o círculo está no domínio distensivo do diagrama, com $\sigma_{3}$ negativo e os outros tensores nulos, formando um ângulo $2 \theta$ com valor próximo ou igual a zero. No caso de juntas de cisalhamento, $\sigma_{1}$ é positivo e os outros nulos, negativos ou positivos, com ângulo $2 \theta$ normalmente 
maior do que $50^{\circ}$. Juntas híbridas estão relacionadas a uma condição intermediária, na qual $\sigma_{1}$ é necessariamente positivo e $\sigma_{3}$ negativo, com ângulo $2 \theta$ com valores entre $10^{\circ}$ e $50^{\circ}$ (figura 7 ).

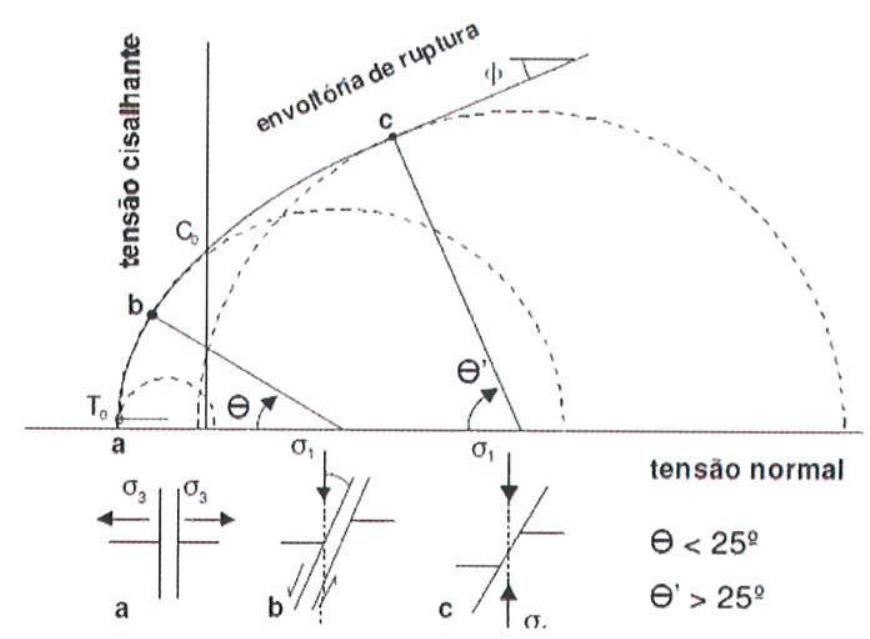

Figura 7 - Diagrama Mohr-Coulomb. Os círculos tracejados representam: (a) juntas de distensão, (b) juntas híbridas, (c) juntas de cisalhamento. Extraído de Roldan (2007), segundo Price \& Cosgrove (1990).

As posições dos esforços principais obtidos a partir de amostras isotrópicas sujeitas a compressão triaxial demonstram a relação angular na orientação dos eixos de esforços principais $\sigma_{1} \sigma_{2}$ e $\sigma_{3}$, como representado na figura 8 .

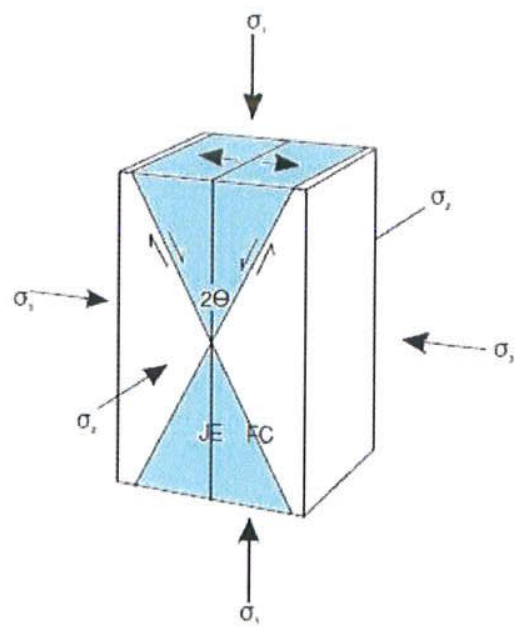

Figura 8 - Relação angular entre os três eixos principais de esforços e juntas formadas.

Desta forma, utilizando os critérios citados, famílias de juntas permitem estabelecer direções dos esforços horizontais máximos $\left(\mathrm{SH}_{\text {máx }}\right)$ e esforços horizontais mínimos $\left(\mathrm{SH}_{\min }\right)$. A figura 9 representa diferentes classes de juntas 
e suas relações com as direções de esforço máximo e mínimo, pressupondo um maciço ideal e isotrópico. Em juntas de distensão, $\sigma_{3}$ é perpendicular à direção média das juntas e, consequentemente, o $\sigma_{1}$ é paralelo. Em sistemas conjugados (hibridos ou de cisalhamento) a direção do esforço horizontal máximo coincide com a bissetriz do ângulo agudo correspondente a orientação média das familias de juntas.
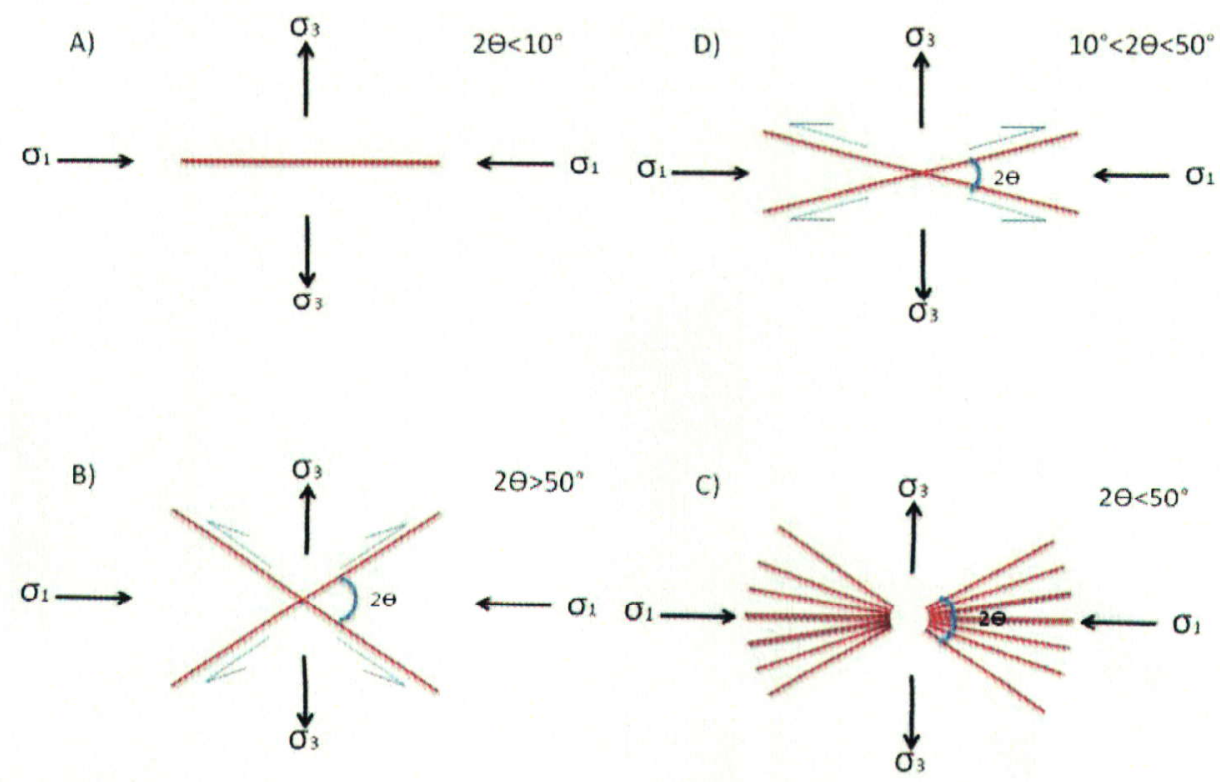

Figura 9 - Classes de juntas e relaçăo geométrica entre os eixos de esforço máximo e mínimo. (a) Juntas de distensão; (b) Juntas conjugadas híbridas; (c) Juntas conjugadas de cisalhamento; (d) espectro de juntas - distensão e hibridas em conjunto. Modificado de Dunne \& Hancock (1994).

Além dos arranjos geométricos de juntas acima descritos existe o denominado arranjo em grid-lock, que corresponde a um sistema de juntas de distensão com famílias ortogunais, relacionadas a um vetor $\sigma_{1}$ constantemente vertical e consecutivas inversões locais de $\sigma_{2}$ e $\sigma_{3}$, distensivos e de magnitudes semelhantes (Caputo 1995) (figura 10). 

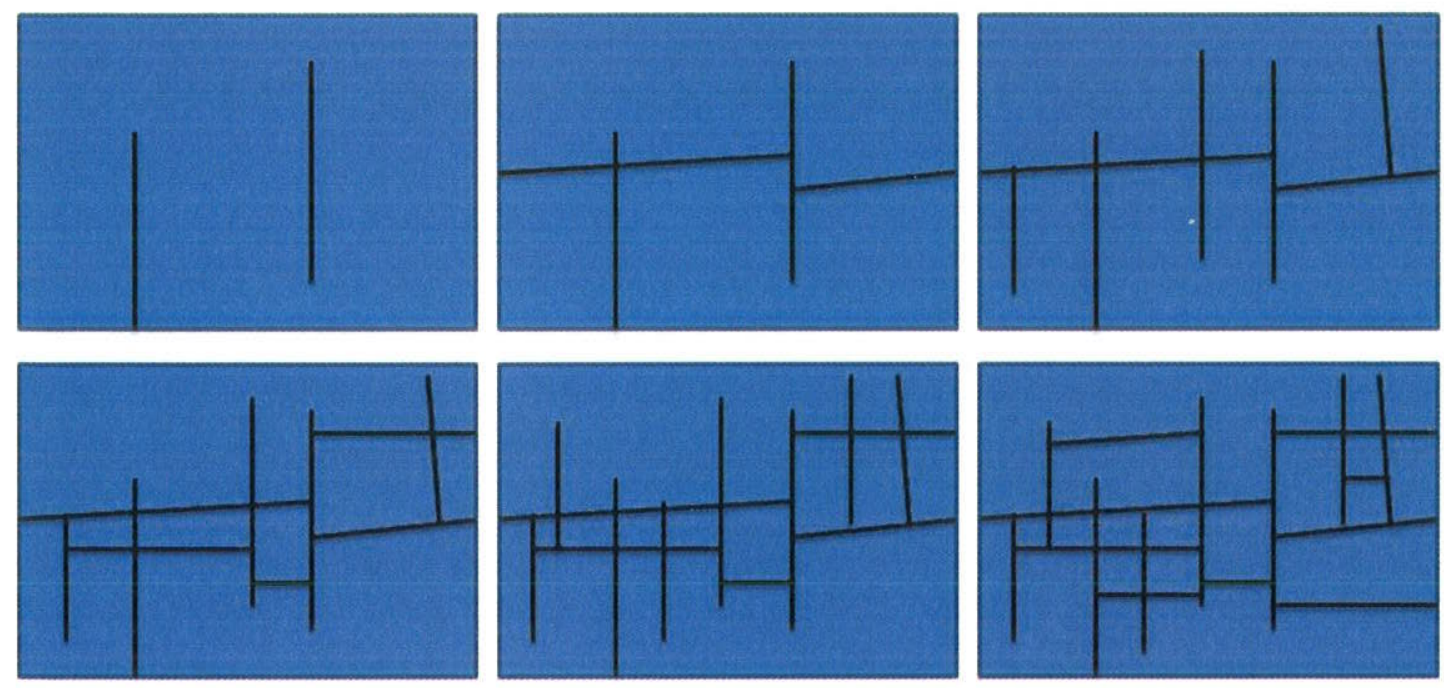

Figura 10 - Croquis esquemáticos da formação progressiva em seis eventos do sistema grid-lock, composto por famílias de direção ortogonal. Modificado de Chiessi (2004), segundo de Caputo (1995).

O termo falha diz respeito a uma descontinuidade de natureza rúptil, ou fratura, na qual, em mesoescala, é possível determinar o deslocamento relativo entre blocos adjacentes utilizando-se marcadores estratigráficos e/ou indicadores cinemáticos existentes nos planos de falhas (Angelier, 1994). A análise dessas feições é utilizada para a determinação de esforços tectônicos pretéritos em estudos estruturais.

De maneira geral, a classificação tripartite, a mais usual para falhas, é a de Anderson (1951), que compreende falhas dos tipos normal, inversa e transcorrente, associadas à orientação das direções principais de esforços (figura 11). Em regimes distensivos o vetor vertical é composto pelo $\sigma_{1}$, em regimes transcorrentes o vetor vertical é $\sigma_{2}$ e em regimes compressivos o vetor vertical observado é $\sigma_{3}$. 

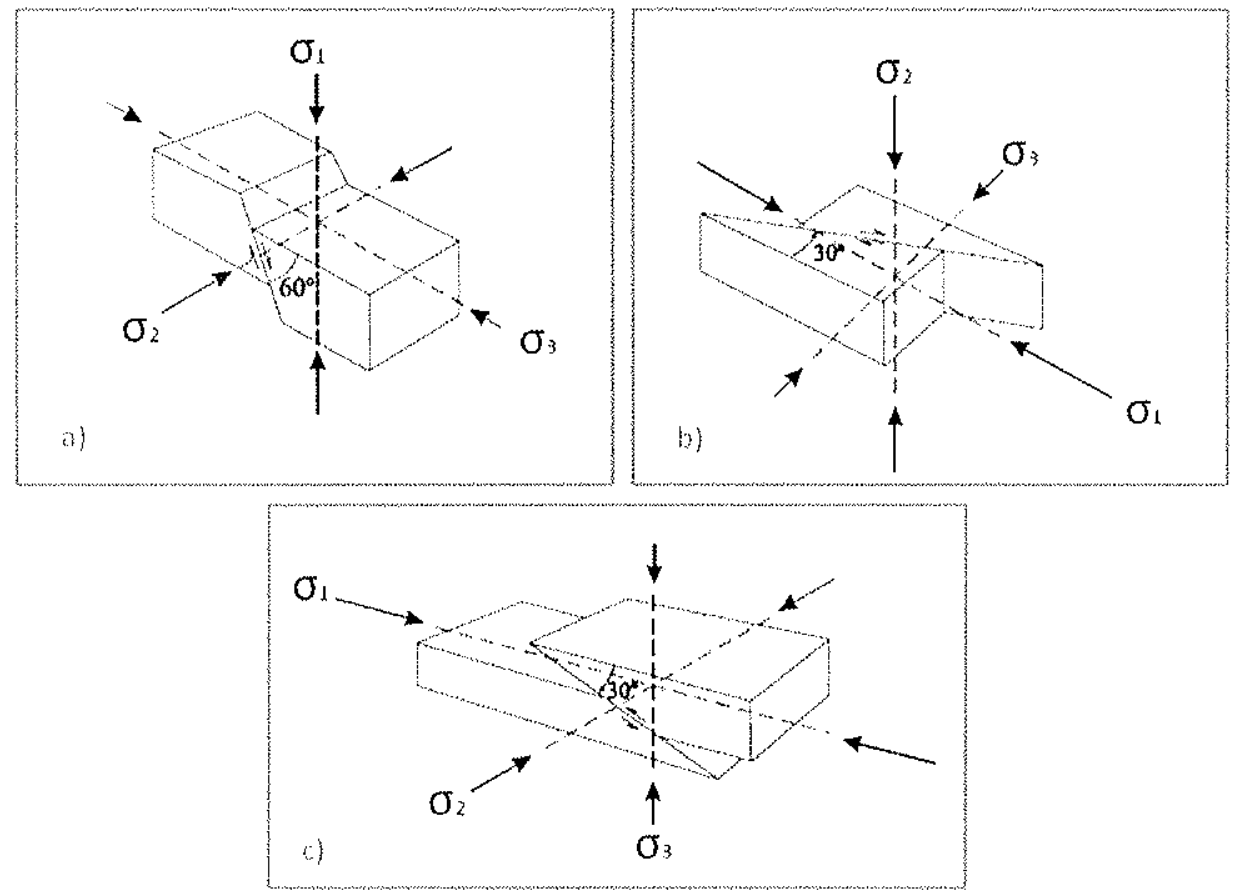

Figura 11 - Classificação dos principais tipos de falhas: a) falha normal; b) falha transcorrente; c) falha inversa. Modificado de Anderson (1951).

Portanto, o movimento relativo entre blocos adjacentes, que determina uma feição rúptil normalmente planar, caracteriza estruturas chamadas falhas. O sentido de movimento desses blocos é determinado por marcadores estratigráficos e indicadores cinemáticos que ficam, muitas vezes, registrados nos planos de ruptura, chamado plano de falha.

A determinação de paleoesforços a partir da análise de falhas é efetuada com base em dados pareados de falhas e estrias. Para cada falha ou superfície de falha é determinada sua atitude (direção e mergulho), bem como das lineações presentes nesta superfície. Estas lineações podem ser diretamente observadas como estrias de atrito ou agregados de cristais de minerais, estes crescidos durante o deslocamento da falha. Podem a ainda ser determinadas a partir de diferentes tipos de feições rugosas assimétricas desenvolvidas na superfície de falha, durante o falhamento, e que dependem, entre outros fatores, da composição das rochas envolvidas. As feições assimétricas podem ser classificadas em positivas, casos em que ocorre menor 
fricção ao tato no sentido do movimento do bloco oposto, ou negativas, nos casos de maior fricção ao tato no sentido de movimento do bloco oposto.

Angelier (1994) e Petit (1987) discutiram as relações entre feições contidas nos planos de talhas, geradas em ambiente rúptil de cisalhamento simples (figuras 12 e 13). Caracteristicamente alguns critérios apresentados implicam na identificação de estruturas secundárias associadas ao plano principal de ruptura, normalmente nomeado de $\mathrm{Y}$. Essas estruturas secundárias foram estabelecidas por Riedel (1929), que identificou fraturas sintéticas (R) e antitéticas ( $\left.R^{\prime}\right)$, desenvolvidas com a progressão da deformação cisalhante até a ruptura no plano principal. Posteriormente, a partir de experimentos com materiais para escala reduzida e observações na natureza efetuadas por outros autores (v.g. Tchalenko 1970), foram reconhecidas outras feições rúpteis sintéticas $(P)$, antitéticas $(X)$ e fraturas de distensão, essas últimas paralelas ao eixo de compressão máxima situado na bissetriz aguda entre R e R' (figura 14).

a)

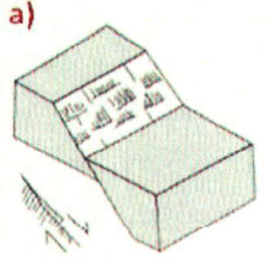

d)

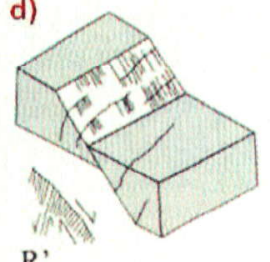

$\mathrm{R}^{\prime}$

g)

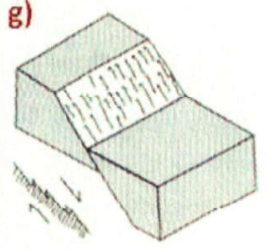

b)

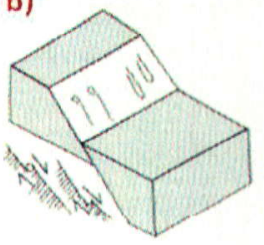

e)

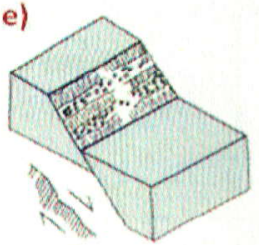

h)

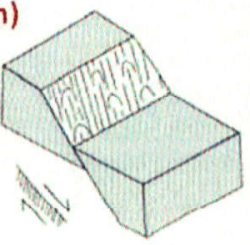

c)

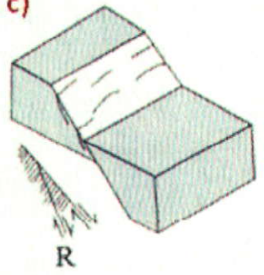

f)

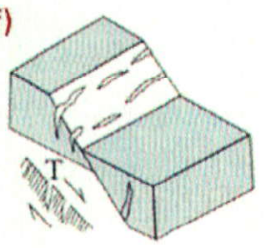

i)

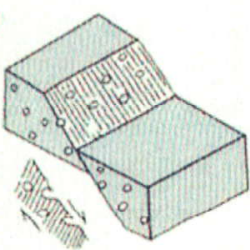

Figura 12 - Exemplos de critérios para a determinação cinemática em planos de falhas: a) degraus formados pelo crescimento mineral (neoformados); b) marcas de objetos; c) falhas sintéticas (R); d) falhas antitéticas ( $\left.R^{\prime}\right)$; e) facetas polidas e rugosas; f) "tension gashes", fraturas tipo $T ; g$ ) picos ou lineações estilolíticas, formadas por dissoluções; $h$ ) marcas parabólicas com a concavidade no sentido do movimento do bloco abatido; i) vesículas deformadas em lavas. Extraído de Angelier (1994). 


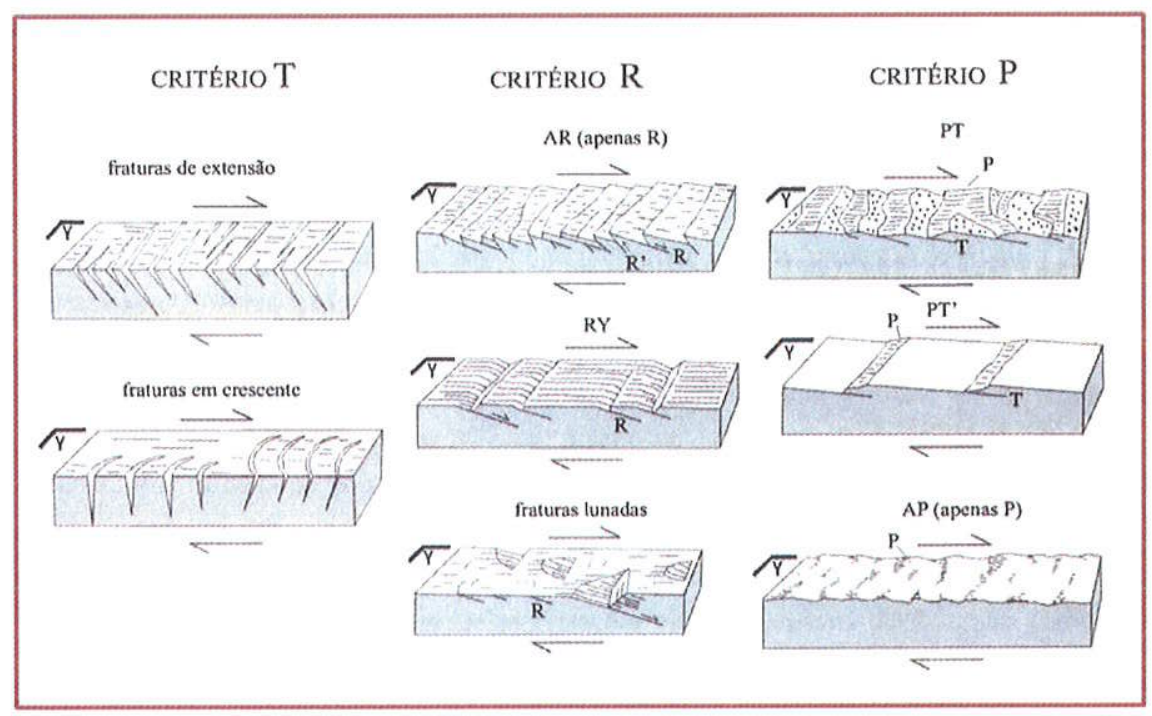

Figura 13 - Critérios para determinação cinemática no contexto de cisalhamento simples, segundo Petit (1987).

Adicionalmente, outras estruturas podem ser formadas quando associadas ao mesmo binário cisalhante, tais como falhas inversas, normais e dobras (figura 15).

Em zonas de cisalhamento essas feições são características e ajudam a compreender a natureza do movimento em grande escala. Na figura 16 são apresentadas estruturas secundárias escalonadas (en echelon) geradas pelo movimento ao longo de faixas de cisalhamento simples, compiladas por Sylvester (1988).

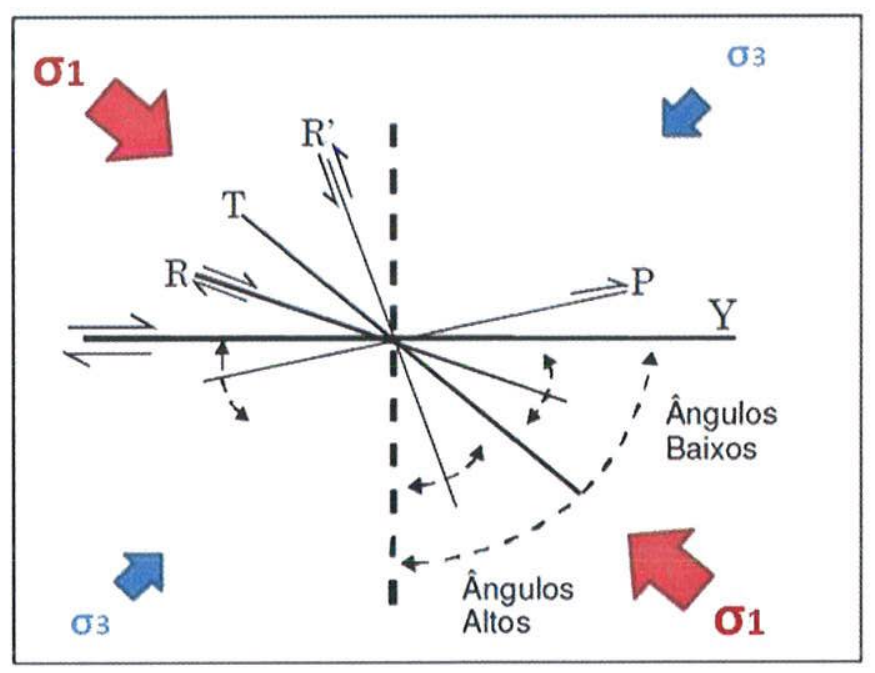

Figura 14 - Ilustração para estruturas secundárias resultantes de um binário destral em contexto de cisalhamento simples - Modelo de Riedel, segundo Petit (1987). 


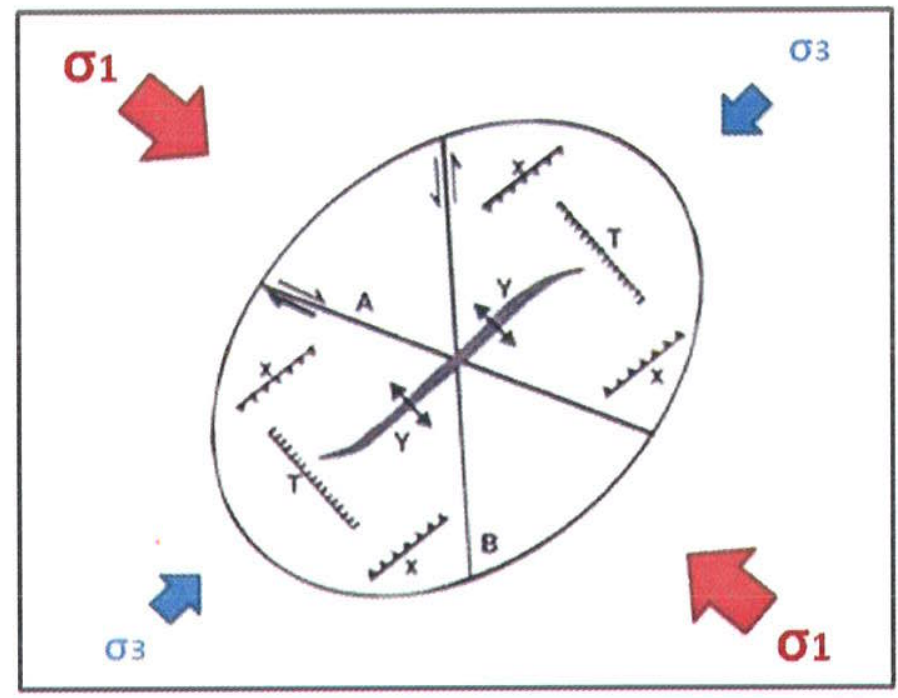

Figura 15 - Elipsóide de deformação em binário destral ilustrando estruturas secundárias: A) falhas sintéticas; B) falhas Antitéticas; X) falhas inversas; Y) dobras e diápiros; T) falhas normais, diques e diáclases. Modificado de Zalán (1986).

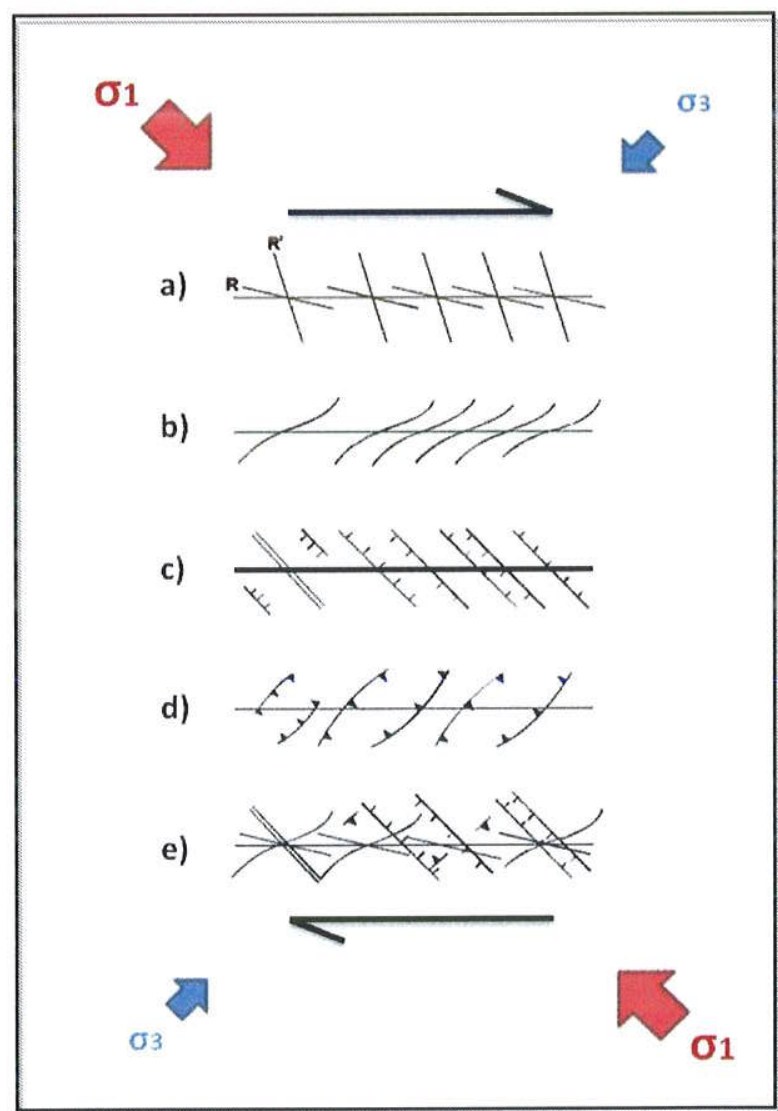

Figura 16 - Estruturas secundárias en echelon associadas a uma zona de cisalhamento destral. As estruturas compiladas são: a) falhas sintéticas e antitéticas; b) dobras; c) fraturas de distensão; d) falhas de empurrão; e) sobreposição das estruturas anteriores. Segundo Sylvester (1988). 


\section{DIQUES COMO INDICADORES DE ESFORÇOS TECTONNICOSOS}

Diques são corpos ígneos tabulares, discordantes ortogonal ou obliquamente das estruturas da rocha encaixantes $e$, geometricamente, de espessura variável e com uma relação comprimento/espessura de 1000:1 (Rickwood 1990), muitas vezes, com mergulhos verticais ou sub-verticais. De acordo com Rickwood (1990) esses corpos podem classificados de acordo com suas relações geométricas no plano horizontal entre comprimento e espessura, conforme a tabela 1. Diques ocorrem como corpos geograficamente isolados ou em grupos geneticamente contemporâneos, constituindo enxames de diques.

\begin{tabular}{|c|c|c|}
\hline Terminologia & Espessura & Comprimento \\
\hline Microdique & $<1 \mathrm{~cm}$ & $<2 \mathrm{~m}$ \\
\hline Minidique & $1-10 \mathrm{~cm}$ & $2-20 \mathrm{~m}$ \\
\hline Dique & $0,1-50 \mathrm{~m}$ & $0,1-50 \mathrm{~km}$ \\
\hline Macrodique & $50-250 \mathrm{~m}$ & $50-250 \mathrm{~km}$ \\
\hline Megadique & $>250 \mathrm{~m}$ & $>250 \mathrm{~km}$ \\
\hline
\end{tabular}

Tabela 1 - Classificação recomendada para a descrição de diques (Modificado de Rickwood 1990).

As atitudes de diques são boas indicadoras de esforços tectônicos, pois ficam normalmente posicionadas ortogonalmente ao vetor de menor esforço horizontal, como demonstrado por muitos autores ( $\mathrm{v} . \mathrm{g}$. Zoback et al. 1989, Zoback 1992, Ferrari 2001, Chiessi 2004, Riccomini et al. 2006).

A colocação desses corpos tabulares, bem como outros corpos intrusivos de forma elíptica, está normalmente correlacionada ao tensor de menor esforço, $\sigma_{3}$, bem como intrudindo estruturas do tipo $T$ que, de acordo com Wilcox et al. (1973), desenvolvem-se no início do processo de deformação pelo regime de cisalhamento simples, sendo muitas vezes obliteradas $\sin$ ou tardi-processo por estruturas do tipo $R$ e $R^{\prime}$ que corroboram para a determinação de tensões então vigentes. Geoffroy et al. (1993) demonstraram grande concordância entre a implantação desses corpos intrusivos e esforços 
horizontais máximos estimados através da atitude de falhas em um mesmo campo de tensões

Segundo Pollard (1987) a intrusão do magma acontece com uma geometria elíptica ou como uma cunha, que deforma elasticamente a rocha encaixante. O dique é colocado sob condições nas quais a pressão do magma é maior que a soma do menor esforço horizontal e a resistência a tração, exercida pelas rochas adjacentes, o que define a forma e direção de propagação do dique, gerando, normalmente, fraturas paralelas nas proximidades dos limites da intrusão.

Apesar da confiabilidade, o emprego dos diques como indicadores de direções de esforços tectônicos deve ser feito de forma criteriosa, pois pode acarretar em desvios na direção estimada de propagação. De maneira geral, segundo Zoback (1992), em diques colocados próximos a superfície, existe uma tendência de a intrusão aproveitar feições preexistentes, principalmente quando os outros dois vetores de esforços, máximo $\left(\sigma_{1}\right)$ e intermediário $\left(\sigma_{2}\right)$ tem magnitudes próximas ao vetor de esforço mínimo $\left(\sigma_{3}\right)$.

Segundo Pollard (1987) a variação no sentido do vetor de esforço mínimo $\left(\sigma_{3}\right)$, na abertura da fratura, por ocasião da propagação do magma em função do campo de esforços atuante na sua extremidade, pode causar variações na morfologia tabular dos diques. Essas variações geram três possíveis modos de fraturas segundo a mecânica mencionada, sendo elas: Modo Puro I, Modo Misto I-II e Modo Misto I-III (figura 17). 
a)

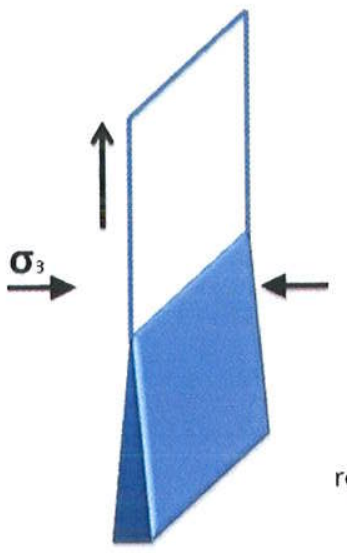

Dique planar b)

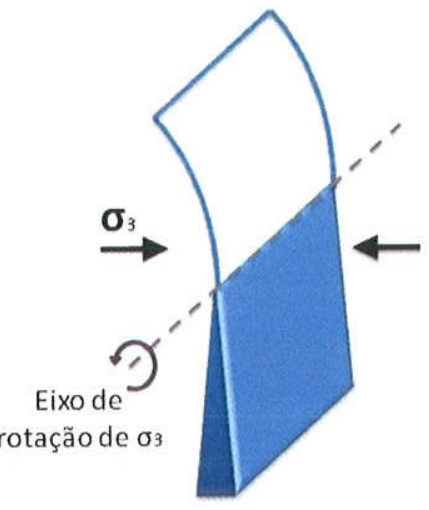

Dique curvado

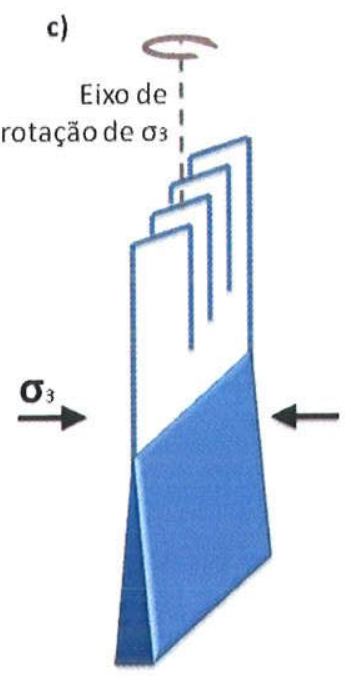

Dique segmentado

Figura 17 - Morfologia de diques relacionados à variação espacial do menor vetor de esforço compressivo $\left(\sigma_{3}\right)$ e: a) Modo Puro l: apresenta $\sigma_{3}$ com direção constante perpendicular ao plano do dique - dique planar; b) Modo Misto I-Il: rotação do $\sigma_{3}$ segundo eixo paralelo a direção planar do dique - dique curvado; c) Modo Misto I-III: rotação do $\sigma_{3}$ segundo o eixo de propagação do dique - dique segmentado. Extraído de Chiesse (2004), segundo Pollard (1987).

Essa relação na rotação das direções de tensões principais na colocação dos corpos ígneos acontece, por vezes, rumo à superfície, gerando um arranjo en echelon, comumente associado a regimes transcorrentes, gerados sob mecanismo de cisalhamento simples (Tchalenko 1970, Wilcox et al. 1973). 


\section{CONTEXTO GEOLÓGICO E TECTÔNICO REGIONAL}

\subsection{AS PRINCIPAIS UNIDADES LITOESTRATIGRÁFICAS RELACIONADAS À ZONA DE CISALHAMENTO JUNDIUVIRA}

O mapa geológico, modificado de CPRM (2006), ilustra as grandes unidades geológicas seccionadas ou delimitadas pela ZCJ (figura 18). As unidades representadas (em função da escala do mapa) apresentam idades arqueanas a mesozóicas, embora em alguns locais, como no Planalto de Campos do Jordão, na ZCJ interesse também às coberturas sedimentares cenozóicas.

O embasamento pré-cambriano (usualmente designado também de embasamento cristalino), exposto na porção centro-leste do Estado de São Paulo, engloba diversas unidades de diferentes naturezas genéticas e evolutivas, com idades variando do Arqueno ao Eo-Paleozóico, organizadas em faixas de dobramentos e maciços de dimensões variadas, por vezes delimitadas por extensas zonas de cisalhamento, dentre as quais a ZCJ.

Segundo Hasui et al. (1980), as unidades pré-cambrianas do estado, além da sua evolução no Ciclo Brasiliano, remontam em termos de origem e retrabalhamento a eventos anteriores, desde o Arqueno. Dessa forma, a definição, delimitação e sistematização das diferentes unidades nem sempre é consensual.

As principais unidades de interesse à ZCJ são descritas a seguir. 


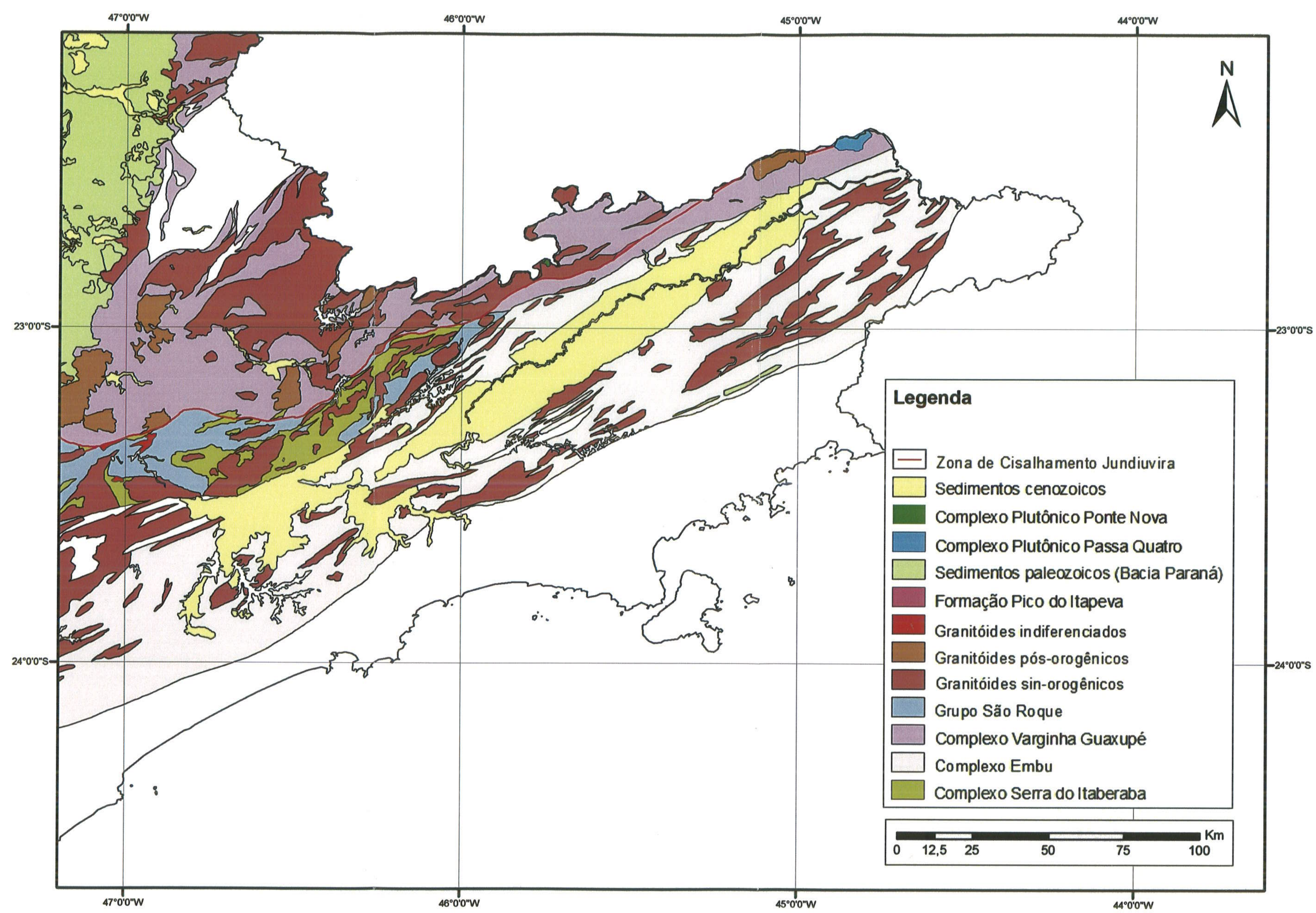

Figura 18-Mapa geológico regional simplificado de parte das unidades geológicas presentes na porção centro-leste do Estado de São Paulo; em vermelho o traçado da ZCJ. Modificado de CPRM (2006). 


\subsubsection{GRUPO SERRA DO ITABERABA}

O Grupo Serra de Itaberaba, definido por Juliani et al. (1986), é uma sequência metavulcanossedimentar subdividida em três unidades. Na base tem-se a Formação Morro da Pedra Preta composta por rochas metamáficas, com estruturas do tipo pillow lava preservadas, intercaladas com metapelitos, e subordinamente rochas vulcanoclásticas e calcissilicáticas, metassedimentos grafitosos e formações ferríferas. A unidade intermediária, Formação Nhanguçu, de natureza clasto-química, é formada por metapelitos que gradam a metapelitos ricos em cálcio intercalados com rochas calcissilicáticas, metatufos e metabasaltos. Em contato gradacional, encontra-se sobreposta a Formação Pirucaia, unidade superior do grupo, que encerra quartzitos, xistos quartzosos e muscovita-biotita quartzitos, por vezes intercalados com biotitamuscovita-quartzo xistos, metapelitos, quartzitos feldspáticos e metarcóseos (Juliani 1993).

O Grupo Serra do Itaberada possui suas rochas deformadas por inúmeros eventos superpostos regionais, com deformações reconhecidas e associadas às reativações das zonas de cisalhamento Jundiuvira e do Rio Jaguari (Juliani 1993).

\subsubsection{COMPLEXO EMBU}

O Complexo Embu (Hasui 1975) é uma faixa alongada anastomosada de direção nordeste, limitada pelas falhas Taxaquara, Jaguari e Monteiro Lobato ao norte e pela falha de Cubatão ao sul (Hasui et al. 1981). No Mapa Geológico do Estado de São Paulo (IPT 1981), esta unidade está contida na descrição do Grupo Açungui e é descrita por migmatitos e gnaisses migmatizados (Hasui et al. 1981). No presente trabalho seguiu-se a divisão proposta pela CPRM (2006), na qual o Complexo Embu é subdividido em sete unidades, sendo que a área de abrangência escolhida compreende três delas:

- unidade de xistos, localmente migmatíticos

Constituída de muscovita-biotita-quartzo xistos, quartzo xistos alternados ritmicamente com rochas calcissilicáticas, anfibolitos e rochas 
metaultramáficas; unidade de gnaisses bandados, composta por biotita gnaisses graníticos e granodioríticos, biotita gnaisses monzodioríticos blastomiloniticos, biotita-hornblenda gnaisses tonalíticos, hornblenda-granada gnaisses, biotita anfibolitos, anfibolitos, quartzitos $e$ intercalações de calcissilicáticas boudinadas;

- unidade paragnáissica

Compreende muscovita-granada-sillimanita-biotita gnaisses migmatíticos, biotita gnaisses tonalíticos a granodioríticos, sillimanita-biotita xistos gnaissóides e biotita gnaisses quartzosos.

\subsubsection{COMPLEXO VARGINHA-GUAXUPÉ}

Inicialmente denominado como Grupo Varginha (Ebert 1971) para descrever rochas granito-gnáissicas, foi posteriormente designado de Complexo Varginha-Guaxupé (Schobbenhaus Filho 1981). É subdividido em três unidades, das quais a intermediária e a superior encontram-se na área de influência da ZCJ, e são descritas como:

- unidade ortognáissica migmatitica intermediária

Composta por migmatitos descritos como biotita-hornblenda nebulito de composições granodiorítica, granítica, sienítica e monzonítica em contato transicional com batólitos de granito-gnaisse de textura normalmente porfirítica.

- unidade paragnáissica migmatitica superior

Composta por migmatitos derivados de rochas metassedimentares cordierita-granada-sillimanita-biotita gnaisse bandado com leucossomas contendo biotita e granada, que gradam para o topo para micaxisto com leucossoma com muscovita, incluindo ainda gnaisses básico-intermediários e rochas metabásicas, além de nebulitos gnáissico-graníticos, ortognaisses, metacarbonatos e gnaisses calcissilicáticos subordinados (Campos Neto 1991). 


\subsubsection{GRUPO SÃO ROQUE}

Inicialmente designadas de Série São Roque (Moraes Rego 1933), as rochas metassedimentares que ocorrem a oeste e norte da Cidade de São Paulo e ao sul da ZCJ foram posteriormente designadas de Grupo São Roque (Hasui et al. 1969), denominação atualmente aceita. Essas rochas foram originalmente consideradas como uma extensão do Grupo Açungui, do qual foram posteriormente separadas com base em critérios deformacionais (Hasui 1973). Em trabalhos posteriores o grupo foi dividido em três (Bergmann 1988) ou quatro (Juliani \& Beljavskis 1995) formações, sendo esta classificação a seguida nesta dissertação.

\section{- Formação Pirapora do Bom Jesus}

Inclui rochas metavulcânicas na base (ortoanfibolitos de granulação fina a grossa, associadas a niveis de cromititos em talco xistos e niveis de hematita, além de ortoanfibolitos finos com textura amigdalóide e estruturas do tipo pillow lava) e metacarbonáticas no topo (calcifilitos de carbonato, quartzo, actinolita, opacos e, mármores dolomíticos finos localmente bandados com estromatólitos).

- Formação Piragibu

Compreende metaconglomerados, metabrechas e, predominantemente, metarritmitos feldspáticos, com intercalações pouco espessas de filito, por vezes grafitoso, ardósia, metarenito, metarcóseo, raros metabasitos e rochas vulcanoclásticas.

- Formação Estrada dos Romeiros

Compreende um membro rudáceo na base (quartzito fino brechado, metaconglomerados) que granodecresce para metarenitos e metapelitos ardosianos bandados no topo.

- Formação Boturuna

Compreende dois membros vulcânicos (ortoanfibolitos com niveis métricos de metatufos laminados, rochas metabásicas extrusivas amigdalóides 
e vesiculares) e dois arenosos (metarenitos arcoseanos bandados com bancos métricos de metapelitos, metarenitos bandados).

\subsubsection{ROCHAS GRANITICAS}

O magmatismo granítico compõe grande parte das rochas da plataforma no estado de São Paulo, ocupando grande parte dos diferentes compartimentos do pré-cambriano.

No Mapa Geológico do Estado de São Paulo, escala 1: 500.000 (IPT 1981) as suites de rochas granitóides são divididas em três categorias distintas: sin-tectônicas, pós-tectônicas e indiferenciadas, neste último caso quando apresentam relações complexas entre as fases intrusivas.

No presente trabalho adotou-se a proposta da CPRM (2006), mantendose a divisão tripartite do IPT (1981), resultando na classificação dos corpos como granitóides pré- a tardiorogênicos ou colisionais, pós-orogênicos e tectonicamente indiferenciados. Esses corpos são intrusivos em rochas dos complexos Varginha-Guaxupé e Embu.

De interesse ao presente trabalho é o granito pós-orogênico de Itu, caracterizado como granitos tipo-A, de composição monzodioritica, quartzomonzodiorítica, monzonítica, quartzo-monzonítica e monzogranítica, com textura rapakivi, pós-orogênicos de idade aproximada entre 580 e $590 \mathrm{Ma}$ (Janasi et al. 2009).

\subsubsection{FORMAÇÃO PICO DO ITAPEVA}

A Formação Pico do Itapeva, localizada a sudeste de Campos do Jordão, SP, foi definida por Cavalcante et al. (1979) e posteriormente detalhada por Teixeira (2000). Ela engloba metaconglomerados, metarenitos e metarritmitos silto-argilosos na base e metarenitos e metaconglomerados polimíticos finos e grossos no topo. As rochas possuem estruturas variadas, desde maciça ou com estratificações planomparalelas, cruzadas de baixo ângulo e cruzadas tipo swaley. São observáveis gradações normais e inversas, estruturas de escape de fluídos (dish), slump, imbricações de clastos e possiveis hummockys. 
Teixeira 2000, baseando-se em similaridades estratigráficas com os depósitos da Bacia do Eleutério, discute as possíveis idades com um máximo de $635 \pm 14$ Ma para a sedimentação da bacia em questão.

\subsubsection{ROCHAS SEDIMENTARES PALEOZÓICAS}

As rochas paleozóicas presentes na região delimitada para este trabalho pertencem ao Grupo Itararé (Milani 1997), unidade basal do Supergrupo Tubarão, Bacia do Paraná. São depósitos sedimentares continentais e marinhos, muito diversificados, de idade permo-carbonifera, formados sob influência glacial (v.g. França \& Potter 1988, Milani 1997, Canuto et al. 1997, Castro 2004).

De acordo com França \& Potter (1988) e Castro (2004) o Grupo Itararé, pode ser subdividido e quatro grandes unidades. A três primeiras são reflexos da sedimentação cíclica em um ambiente glacial e variações do nível do mar. $A$ quarta unidade é representada pela formação Aquidauana, temporalmente equivalente as anteriormente citadas, representante de porções marginais do grupo.

\subsubsection{COMPLEXO PLUTÔNICO ALCALINO DE PASSA QUATRO}

O Maciço Alcalino de Passa Quatro é composto, segundo Chiessi (2004), por dois grupos de rochas leucocráticas. O primeiro grupo é composto por rochas de granulação faneríticas formadas predominantemente por nefelina sienitos, ocorrendo sodalita nefelina sienitos e nefelina microssienitos. O segundo grupo é constituído por rochas afaniticas representadas por brechas magmáticas alcalinas, fonolitos, traquitos e lamprófiros.

As rochas do maciço indicam idade aproximada de formação durante o

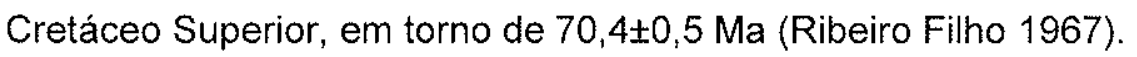




\subsubsection{DEPÓSITOS SEDIMENTARES CENOZÓICOS}

Nas adjacências da ZCJ ocorrem depósitos terciários relacionados ás bacias tafrogênicas do Rift Continental do Sudeste do Brasil (Riccomini 1989) e depósitos aluviais e coluviais quaternários (v.g. Riccomini et al. 2004).

O Rift Continental do Sudeste do Brasil é uma depressão alongada, de direção NE a ENE, que se desenvolve entre Tijucas do Sul, Estado do Paraná, e a área submersa defronte Macaé (Riccomini et al. 2004).O rift pode ser subdivido em três segmentos. O segmento ocidental, que engloba a Bacia de Curitiba e os Grabens de Guaraqueçaba, Cananéia e Sete Barras. O segmento central, composto pelas bacias de São Paulo, Taubaté, Resende e Volta Redonda, assim como depósitos nas regiões de Bonfim e Cafundó. Por fim, o segmento oriental que compreende as bacias Macacu, Itaborai e o Gabem da Barra de São João.

O segmento central, situado nas adjacências da área de estudo e localizado ao sul da ZCJ, é relevante ao presente trabalho por guardar os registros sedimentares que são reflexos de diferentes estágios da evolução tectônica da porção centro-leste do Estado de São Paulo. Neste segmento são reconhecidas as formações Resende (diamictitos e lamitos de leques aluviais, arenitos de sistema fluvial entrelaçado), Tremembé (folhelhos, argilitos e subordinadamente dolomitos lacustres) e São Paulo (conglomerados, arenitos e lamitos de sistema fluvial meandrante), pertencentes ao Grupo Taubaté, de idade paleógena (Eoceno-Oligoceno), cobertas pelos depósitos das formações Itaquaquecetuba (arenitos e conglomerados de sistema fluvial entrelaçado), miocena, e Pindamonhangaba (conglomerados, arenitos e lamitos de sistema fluvial meandrante), de idade miocena a pliocena (Riccomini et al. 2004) (figura 19). 


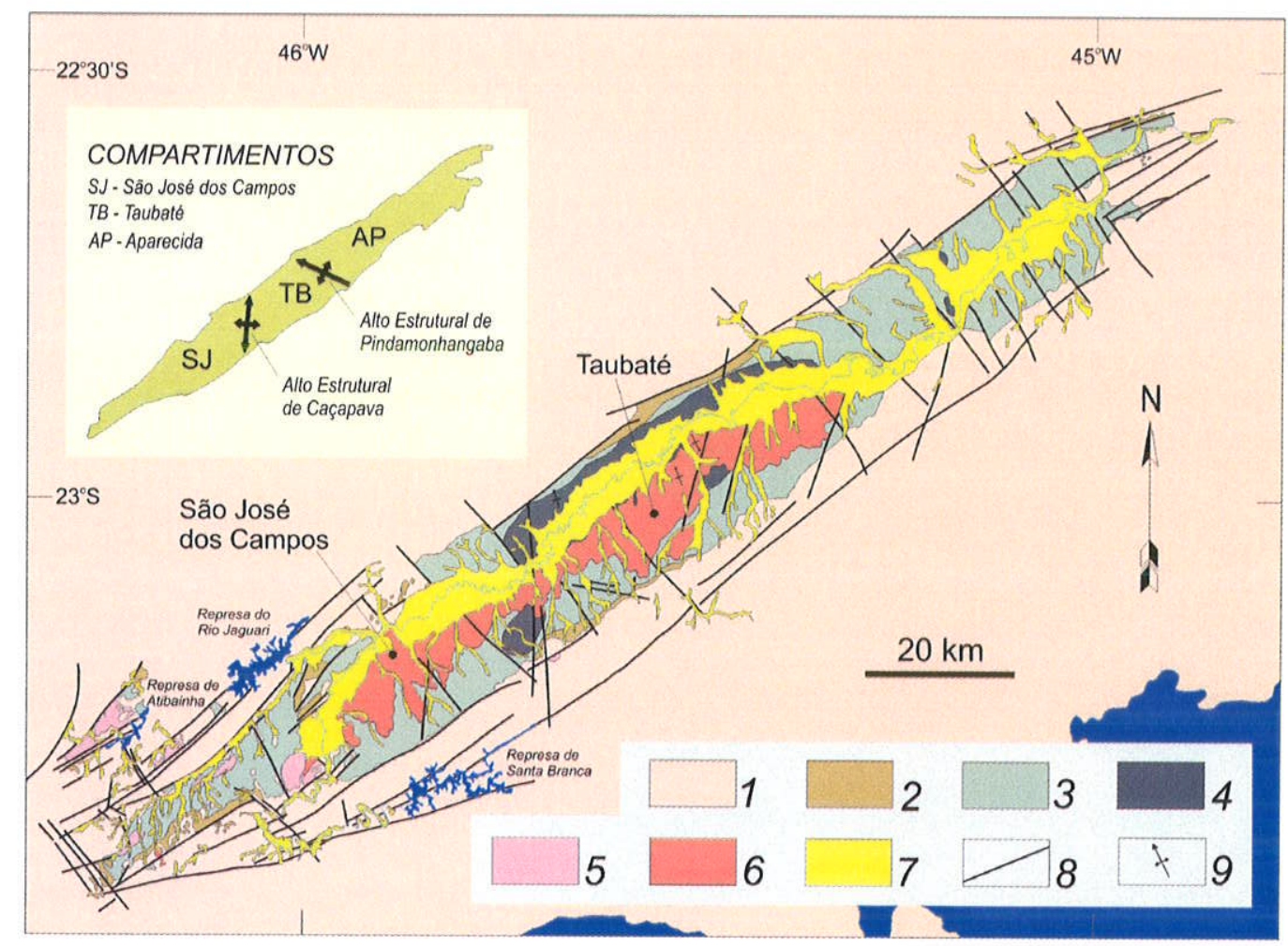

Figura 18 - Mapa geológico do segmento central do Rift Continental do Sudeste do Brasil. 1) Embasamento pré-cambriano; 2) Formação Resende - sistema de leques aluviais proximais; 3) Formação Resende - sistema de leques aluviais mediano e distais associados a planície aluvial de rios entrelaçados; 4) Formação São Paulo; 6) Formação Pindamonhangaba; 7) sedimentos quaternários; 8) falhas cenozóicas reativadas do embasamento pré-cambriano; 9) eixos de dobras principais. Extraído de Riccomini et al. 2004, segundo Riccomini 1989.

Os depósitos sedimentares quaternários da região são de natureza coluvial ou colúvio-aluvial e cobrem indiscriminadamente as rochas sotopostas. Esses depósitos são normalmente argilo-siltosos a areno-argilosos, possuem colorações que variam entre alaranjados a amarelados. No contato basal dos depósitos coluviais frequentemente ocorre um ou mais camadas maciças de seixos, normalmente arredondados e essencialmente de quartzito, com espessura centimétrica a decimétrica, denominados de linhas-de-pedras ou stone lines, de idade pleistocena terminal (v.g. Modenesi-Gauttieri et al. 2002). Em função de suas idades e posição estratigráfica, os depósitos quaternários da região tem sido alvo de estudos geomorfológicos e como balizadores de eventos neotectônicos (v.g. Riccomini 1989, Hiruma 1999, Modenesi-Gauttieri et al. 2002, Neves 2005). 


\subsection{CONTEXTO TECTÔNICO REGIONAL}

As rochas pré-cambrianas da porção centro-leste do Estado de São Paulo encontram-se enfeixadas no contexto tectônico da Província Mantiqueira (Almeida et al. 1981) e apresentam idades arqueanas a neoproterozoicas. Esta província constitui um sistema orogênico neoproterozoico, que se estende pelo sul e sudeste do Brasil, como resultado da amalgamação do paleocontinente Gondwana Ocidental no Ciclo Brasiliano (Orogenia Brasiliano-Pan Africana) (Heilbron et al. 2004).

O Sistema Orogênico Mantiqueira pode ser dividido nos segmentos setentrional, central e meridional, e engloba os orógenos Araçuaí, Dom Feliciano, São Gabriel, Ribeira e Brasília meridional. Os orógenos Ribeira e Brasília apresentam uma zona de interferência de grande complexidade estrutural (figura 20).

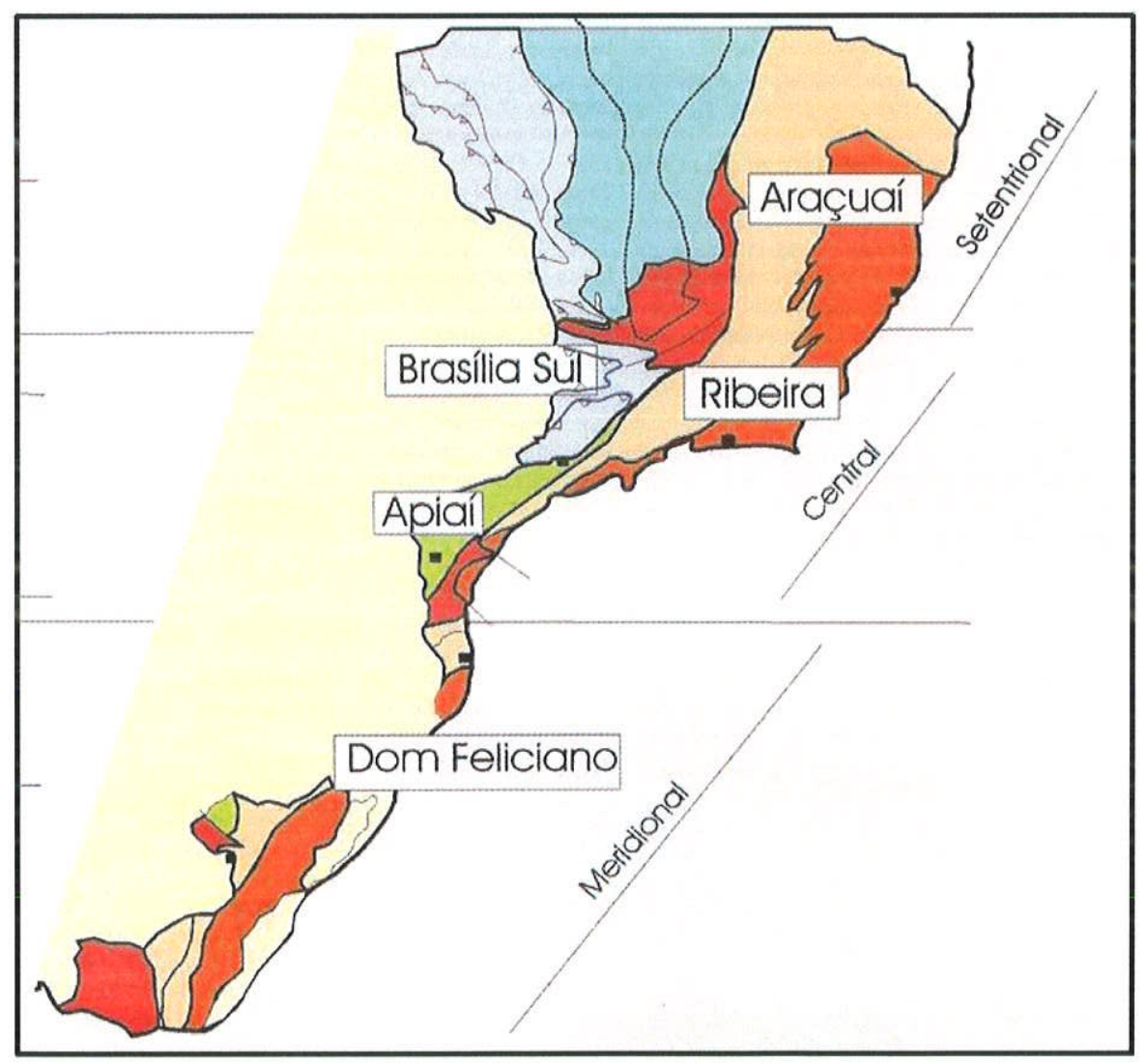

Figura 19 - Subdivisão do Sistema Orogênico Mantiqueira. Segmento setentrional: Orógeno Araçuaí; segmento central: orógenos Brasília Meridional, Ribeira e Apiaí; segmento meridional: orógenos Dom Feliciano e São Gabriel. Extraído de Heilbron et al. (2004). 
A Província Mantiqueira é tectonicamente compartimentada por falhas de empurrão com mergulhos íngremes ou zonas de cisalhamento oblíquas que limitam blocos ou terrenos (Hasui \& Sadowski 1976, Hasui et al. 1980, Heilbron et al. 2004). O sistema de zonas de cisalhamento ou grandes zonas de falhas é caracterizado por um feixe de geometria anastomosada com direção ENE e caráter transcorrente (Hasui et al. 1977, Sadowski \& Campanha 2004).

\subsubsection{AS GRANDES ZONAS DE CISALHAMENTO DO ESTADO DE SÃO PAULO}

A área de ocorrência de rochas pré-cambrianas do Estado de São Paulo é recortada por um sistema de zonas de cisalhamento de orientação geral E-W a ENE (v.g. Sadowski \& Campanha 2004). Individualmente, as zonas de cisalhamento atingem comprimentos de até centenas de quilômetros (figura 21), e a espessura da faixa de rochas deformadas a elas associadas chega a ultrapassar $1 \mathrm{~km}$ de largura.

O reconhecimento desse grande sistema de zonas de cisalhamento resultou de mapeamentos regionais realizados entre as décadas de 1960 e 1970, destacando-se, nesta fase, os trabalhos de Hennies et al. (1967), no qual os autores descreveram a Falha de Taxaquara, Hasui et al. (1969) sobre a Falha de Jundiuvira, Carneiro (1977) na Falha de Buquira, Almeida (1953) e mais tarde Sadowski (1974) na Falha de Cubatão, entre outros. Posteriormente, Hasui et al. (1977) apresentaram uma síntese sobre as principais zonas de cisalhamento do pré-cambriano do Estado de São Paulo, na qual reconheceram que essas descontinuidades apresentam arranjos subparalelos a anastomosados, com grande influência na compartimentação em blocos ou terrenos, que refletem domínios tectônicos com diferentes litologias, estruturas e histórias geológicas

Esse sistema de zonas de cisalhamento já recebeu designações diversas, tais como Zona de Transcorrência de São Paulo (Hasui et al. 1975), Faixa de Cisalhamento São Paulo (Hasui et al. 1984), Cinturão Transcorrente Paraíba do Sul (Ebert et al. 1991), Sistema de Cisalhamento Transatlântico (Machado \& Endo 1993) e Zona de Falhamentos Transcorrentes no Sudeste Brasileiro (Sadowski 1993). 


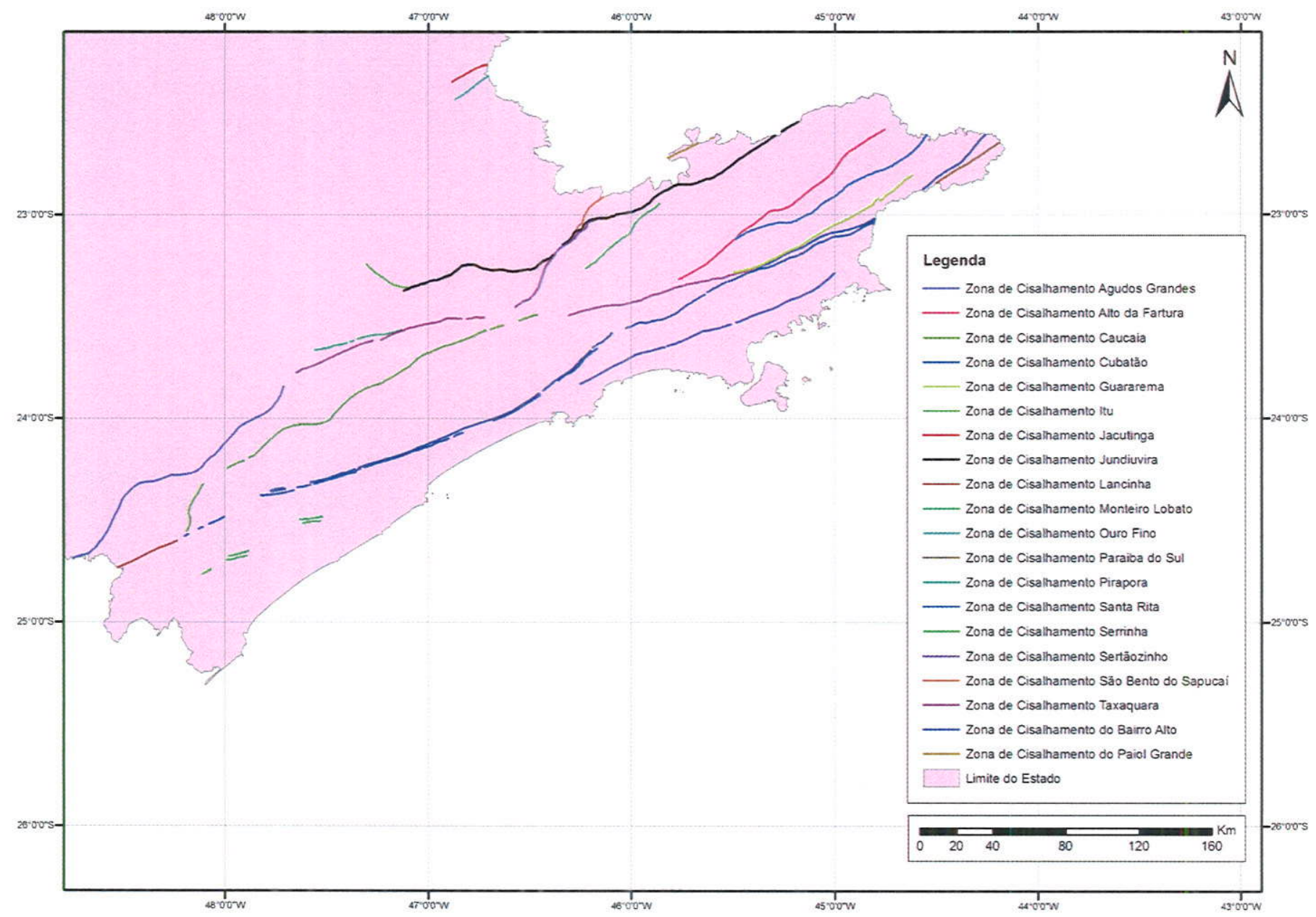

Figura 20 - Mapa de localização das principais zonas de cisalhamento no Estado de São Paulo. Modificado de CPRM (2006). 
Além da clara atividade brasiliana, há evidências de que essas estruturas já existissem pelo menos no Mesoproterozoico, envolvendo faixas de rochas cataclásticas geradas em regime transcorrente, com litotipos variando de protomilonitos a ultramilonitos, por vezes blastomilonitos, com foliação planar subvertical bem desenvolvida e espessuras compativeis com o porte da falha (Hasui et al. 1977). Tal faixa rúptil/dúctil confere aos blocos uma estruturação geométrica alongada e o feixe de falhas possui aparente continuidade sob a Bacia do Paraná, a oeste, e possivel persistência para leste, na zona costeira (Hasui et al. 1980).

Por outro lado, essas grandes falhas têm sua importância relacionada à configuração de blocos ou terrenos presentes no embasamento do sudeste do Brasil, que condicionou a atividade geológica fanerozoica (tectônica, magmática, sedimentar, geomorfogênese, sismicidade).

\subsubsection{REATIVAÇÕES FANEROZOICAS DE ZONAS DE CISALHAMENTO}

A relação entre as grandes zonas de cisalhamento e sua correlação com as unidades existentes do pré-cambriano paulista ainda são especulativas. É reconhecido o caráter transcorrente das zonas de cisalhamento, deslocamento ao qual é atribuída a justaposição de blocos de niveis crustais e idades distintas. Observação relevante diz respeito ao embutimento de unidades como o Grupo São Roque, que aparentemente possui indícios de deslocamentos distensivos ou transtativos sinsedimentares (Wernick et al. 1978). Nessas zonas são também reconhecidos estilos de deformação com sobreposição de cisalhamento dúctil de baixo ângulo por outro de alto ângulo e, localmente, superposição destral em zona transcorrente sinistral (Ebert \& Hasui 1998, Campos Neto \& Basei 1983, Garcia \& Campos Neto, 1997).

Hasui et al. (1984) discutiram a dinâmica das zonas de cisalhamento na parte central da região de dobramentos sudeste. Nesse trabalho os autores sugerem que o feixe de falhas é tardibrasiliano, pois secciona unidades dobradas e metamorfizadas, além de granitóides do Neoproterozoico. Vale assinalar que rochas granitóides ocupam expressiva parcela dos terrenos pré-cambrianos do Estado de São Paulo, e são registros dos processos termotectônicos brasilianos da região sudeste iniciados por volta de $650 \mathrm{Ma}$ (Schobbenhaus et al. 1984). 
Alguns autores entendem que a evolução dos falhamentos não foi continua, mas episódica, com movimentações mais intensas após o magmatismo pós-tectônico. Hasui \& Sadowski (1976) descreveram processos de interação entre estruturas tectônicas e litotipos no Estado de São Paulo, como os stocks alinhados na Falha de Cubatão (Sadowski, 1974) e o Granito Sorocaba (Hasui et al. 1981), um corpo alongado alinhado na Falha de Jundiuvira. Embora sejam considerados como póstectônicos, esses dois corpos graníticos tiveram suas intrusões possivelmente controladas pela atividade das zonas de cisalhamento.

Almeida (1969), ao analisar a "diferenciação tectônica da Plataforma Brasileira", descreveu os estágios de transição, estabilização e reativação.

O estágio inicial, de transição, teria ocorrido no Cambro-Ordoviciano, com a instalação de bacias molássicas, hoje chamadas de Bacias da Transição ProterozoicoFanerozoico (Teixeira 2000), e ativação de antigas zonas de fraqueza. As bacias do estágio de transição, situadas na Província Mantiqueira, estão assentadas sobre rochas de diferentes naturezas, mas controladas por uma trama de blocos ou terrenos com um trend médio orientado segundo ENE.

No Estado de São Paulo, as bacias do estágio de transição estão relacionadas às grandes falhas mencionadas, constituindo pequenos remanescentes de sucessões embutidas e preservadas da erosão ao longo das zonas de cisalhamento. Essas bacias tiveram sua evolução compreendida entre o Ediacarano e o Ordoviciano Inferior a Médio (600-470 Ma), distribuídas por toda a plataforma e, mais especificamente, nos setores central e meridional da Provincia Mantiqueira ( Teixeira et al. 2004, Almeida et al. 2010). Um dos exemplos é a Bacia do Pico do Itapeva, que possui forma lenticular e é limitada por ramificações da Falha de Jundiuvira (Teixeira et al. 2004). A origem da Bacia do Pico de Itapeva, embora ainda muito discutida, possui relação direta com essa estrutura, seja como bacia tipo pull-apart gerada por transcorrência sinistral da ZCJ (Riccomini 1993), ou como bacia distensiva associada à zona transcorrente (strike slip basin), na qual movimentos puramente laterais seriam secundários e póssedimentares (Teixeira 2000). Esses deslocamentos pós-sedimentares seriam responsáveis por tectonismo deformador posterior, por vezes relacionado a inversões causadas por transcorrências destrais em regimes compressivos, como nos casos das zonas de cisalhamento Jacutinga-Três Corações, de Monte Sião, Jundiuvira e da Lancinha. Recentemente, Almeida et. al. (2010) sugeriram origem por um sistema distensivo regional, com depósitos relacionados com escarpas de falhas normais, 
granitogênese regional (em função do afinamento crustal) e, posteriormente, reativação transcorrente.

Independente da gênese ou reativação dos depósitos no estágio de transição, Hartwing \& Riccomini (2009), estudando padrões de fraturas na região da Serra dos Órgãos, identificaram inúmeros eventos, dos quais o primeiro, relacionado a juntas escalonadas verticais de direção NE-SW, preenchidas por quartzo e localizadas no interior de veios aplíticos, remontaria ao Neoproterozoico-Cambriano, sendo caracterizado por transcorrência sinistral com binário de esforços orientado segundo E-W.

O estágio de transição seria sucedido, segundo Almeida (1969) e Almeida \& Carneiro (2004), pela etapa de estabilização ortoplataformal no Ordoviciano, com o aparecimento de grandes bacias intracratônicas, caracterizadas pela relativa calma tectônica e ingressões marinhas no Siluriano (Hasui et al. 1982). O registro sedimentar inicial da Bacia do Paraná pode estar relacionado a um rift inicial, refletindo a evolução tectônica de estruturas herdadas do embasamento proterozoico ou do ciclo brasiliano, reativadas e gerando depocentros ( $\mathrm{V} . \mathrm{g}$. Cordani et al. 1984, Zalán et al. 1990). Esse processo de subsidência mecânica parece ter controlado calhas deposicionais por falhas normais e se estendido até o evento magmático que gerou os basaltos ordovicianos da Formação Três Lagoas (Milani, 2004).

A figura 22 ilustra os elementos estruturais com direção NE-SW na Bacia do Paraná, direções essas coincidentes com as zonas de cisalhamento descritas para o sudeste brasileiro e que possivelmente teriam continuidade para o sul do país (Campanha 2002). 


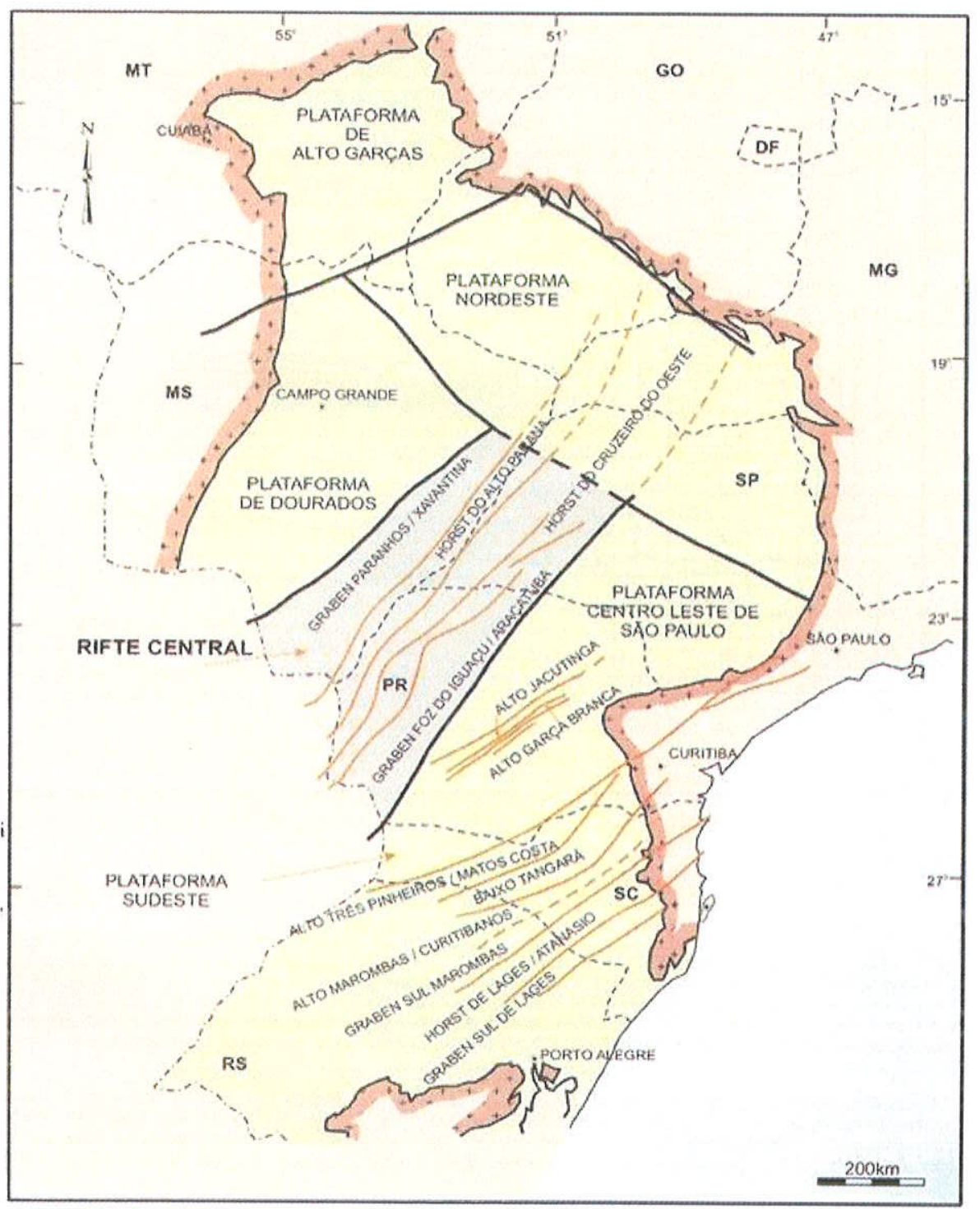

Figura 21 - Arcabouço tectônico da Bacia do Paraná e grandes elementos estruturais de direção NE-SW. Extraído de Milani 2004.

Com a evolução dos conhecimentos na década de 1990, foram reconhecidas evidências de reativação de estruturas rúpteis do embasamento na evolução tectonosedimentar da Bacia da Paraná (Zalán et al. 1990), além de evidências diretas de tectonismo sinsedimentar, como os sismitos (estruturas de liquefação e diques clásticos com direção média de distensão E-W, associadas a campos de esforços com compressão de direção geral N-S), descritos no registro permotriássico desta bacia e relacionados à reativação transcorrente sinistral da Zona de Cisalhamento Jacutinga (Riccomini et al. 1992, Chamani et al. 1992, Riccomini et al. 2005, Turra 2009). 
As atividades tectônicas permotriássicas foram aparentemente precursoras de uma intensa reativação da Plataforma Sul-Americana (Riccomini et al. 1992). Os registros do estágio de reativação, manifestada pela reorganização estrutural da plataforma, com a movimentação de antigas fraturas profundas, abatimento tectônico de blocos e acumulação de sedimentos, seriam as bacias tafrogênicas mesozóicocenozóicas (Almeida 1969). A esse estágio foi inicialmente atribuída a designação de Reativação Wealdeniana (Almeida 1967), posteriormente modificada para Reativação Sul-Atlantiana (Schobbenhaus et al. 1984), por refletir melhor a abrangência do evento em toda a Plataforma Sul-Americana, e que culminaria com a abertura do Atlântico Sul, no Cretáceo Inferior. A abertura do oceano, com consequente subsidência térmica na porção oriental da plataforma, seguido, a oeste, pelo desenvolvimento da Bacia do Paraná, teria importante efeito na região leste continental do Estado de São Paulo (Almeida 1967, Asmus \& Ferrari 1978).

A fragmentação do Gondwana foi condicionada pela de rede de falhas préestabelecida e influenciada por diferentes processos de ruptura, resultantes de mudanças no estado de tensões intraplaca. São propostos diferentes mecanismos para essa ruptura, os quais podem estar relacionados a variações na trajetória da Placa Sul-Americana (Sadowski 1977), efeitos da compensação isostática (Asmus \& Ferrari 1978), ou basculamento termomecânico (Riccomini 1989).

Essa evolução tectônica que desencadeou a tafrogênese do Gondwana foi sumarizada por Macedo (1990), com o início em uma etapa de intumescência termal da região do sudeste brasileiro durante o Jurássico, favorecendo o início de esforços distensivos no Eocretáceo, com o desenvolvimento de falhas normais e juntas na região do Cinturão Ribeira. Tais descontinuidades localizadas no continente e, pertencentes a esse período, serviram de dutos alimentadores das manifestações magmáticas iniciais. Riccomini (1995), Silva (2005) e Riccomini et al. (2006) relacionam os diques basálticos de idade cretácea de direções médias para NE com regimes trativos NW-SE.

Os maciços alcalinos, como já observado por Freitas (1951), são notavelmente correlacionáveis com fenômenos de caráter tectônico. Eles são reconhecidos na porção meridional da Plataforma Brasileira como intrusões pós-paleozóicas distribuídas em três províncias principais na região sudeste, denominadas de Arco de Ponta Grossa, Serra do Mar (Almeida, 1983) e Alinhamento Magmático de Cabo Frio (Riccomini et al. 2005). 
$\mathrm{Na}$ região limitrofe entre os estados de São Paulo, Minas Gerais e Rio de Janeiro ocorrem três maciços alcalinos: o de Ponte Nova, localizado na Serra da Mantiqueira e inserido no contexto da província da Serra do Mar, com idade neocretácea e controlado por falhas de direção NE a ENE; os de Passa Quatro e Itatiaia, incluidos na província do Alinhamento Magmático de Cabo Frio (figura 23), caracterizada por uma extensa zona de fratura transcorrente sinistral, de direção geral WNW, com pelo menos duas fases de reativação e magmatismo associado, no Neocretáceo a Paleoceno e Eoceno (Riccomini et al. 2005). Chiessi (2004) relacionou a colocação do maciço de Passa Quatro a um binário sinistral de orientação E-W, assim como a cinemática do alinhamento. Entretanto, diques que seccionam as rochas alcalinas do Maciço Alcalino de Passa Quatro podem ser vinculados a movimentos destrais de falhas do embasamento com direção $N E$, fato que será discutida posteriormente neste trabalho.

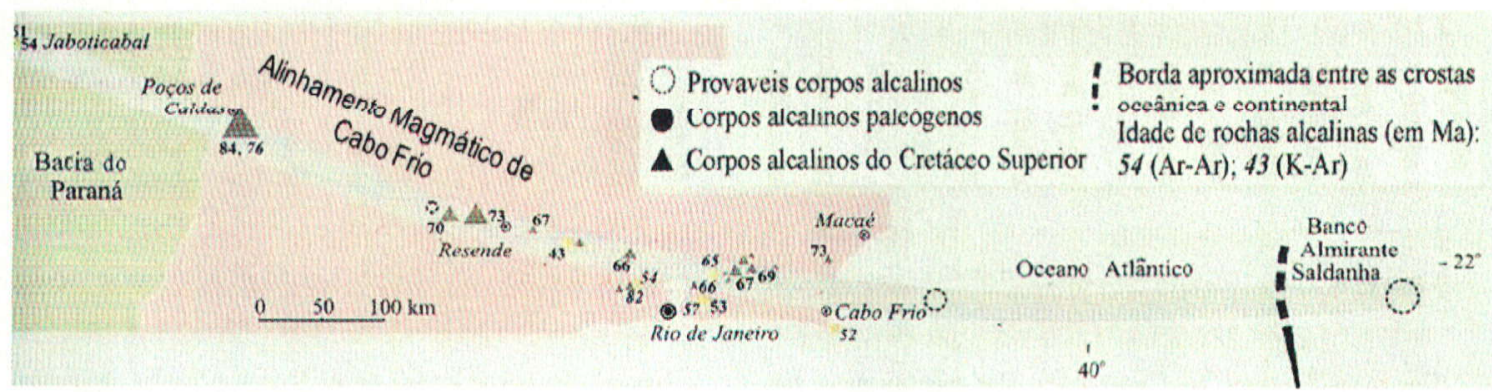

Figura 22 - Alinhamento Magmático de Cabo Frio com distribuição e idade dos corpos alcalinos. Extraído de Riccomini et al. (2005).

Coube a Almeida (1953) a menção inicial às relações da geomorfogênese da Serra de Cubatão e instalação do Sistemas de Rift Valley do sudeste do Brasil com a atividade de falhas. Dois anos mais tarde, o autor (Almeida 1955), em estudo sobre a tectônica da Serra da Mantiqueira, apresentou as primeiras descrições sobre a existência de "falhas transcorrentes antigas e profundas", com reativações recentes e sua relação com a sedimentação cenozóica. Com continuidade dos processos relacionados ao estágio de reativação e a evolução dos estados de esforços, a plataforma sofre com a continua distensão e, na porção continental, evolui para um sistema de montanhas soerguidas por falhas e vales tectônicos associados a bacias sedimentares cenozóicas, feição denominada de Sistemas de Rifts da Serra do Mar 
por Almeida (1976), e posteriormente de Rift Continental do Sudeste do Brasil por Riccomini (1989).

No que tange à origem desse sistema de rifts, Almeida (1976) discute processos ligados ao deslizamento gravitacional e recuo da escarpa das serras adjacentes a essas bacias. Posteriormente, Asmus \& Ferrari (1978), sugerem que após a intumescência termal e consequente ruptura crustal, estabeleceu-se um desequilíbrio isostático, com excesso de massa na área oceânica, que teria gerado movimentos verticais opostos e o soerguimento da área continental, causando consecutivas rupturas (falhas normais com rejeitos na ordem de dezenas de metros), formando horts e grabens. Pensando no acúmulo de massa nas regiões oceânicas e o continuo aumento da densidade da costa oceânica pelo resfriamento, Riccomini (1989) propõe o basculamento termomecânico para o possível mecanismo gerador de tensões de estiramento no Rift Continental do Sudeste do Brasil. Ferrari (2001), analisando o caráter inicial direcional e posterior distensivo para o Graben da Guanabara, considerou a existência de um soerguimento predecessor e a resposta às anisotropias mecânicas do manto sotoposto por ocasião da implantação de um regime direcional nos rifts.

Para o segmento central do Rift Continental do Sudeste do Brasil, Riccomini (1989) apresentou modelos tectônicos para a geração e deformação dessas bacias. $O$ autor propôs que inicialmente teria sido formada uma depressão alongada e extensa, com concomitante preenchimento vulcano-sedimentar, entre o Eoceno e Oligoceno, resultante de um campo de esforços distensivos de direção NNW-SSE, causador da reativação em falhas mestras normais de zonas de cisalhamento proterozoicas com direções entre NE e ENE.

Diferentes mecanismos de variações de esforços intraplaca são propostos para explicar processos deformadores em bacias cenozóicas localizadas no sudeste do Brasil. Com a evolução dos conhecimentos essas deformações têm sido progressivamente melhor definidas e delimitadas cronologicamente. As figuras 24 e 25 apresentam o quadro litoestratigráfico e a evolução tectônica no segmento central do Rift Continental do Sudeste do Brasil (Riccomini et al. 2004). 


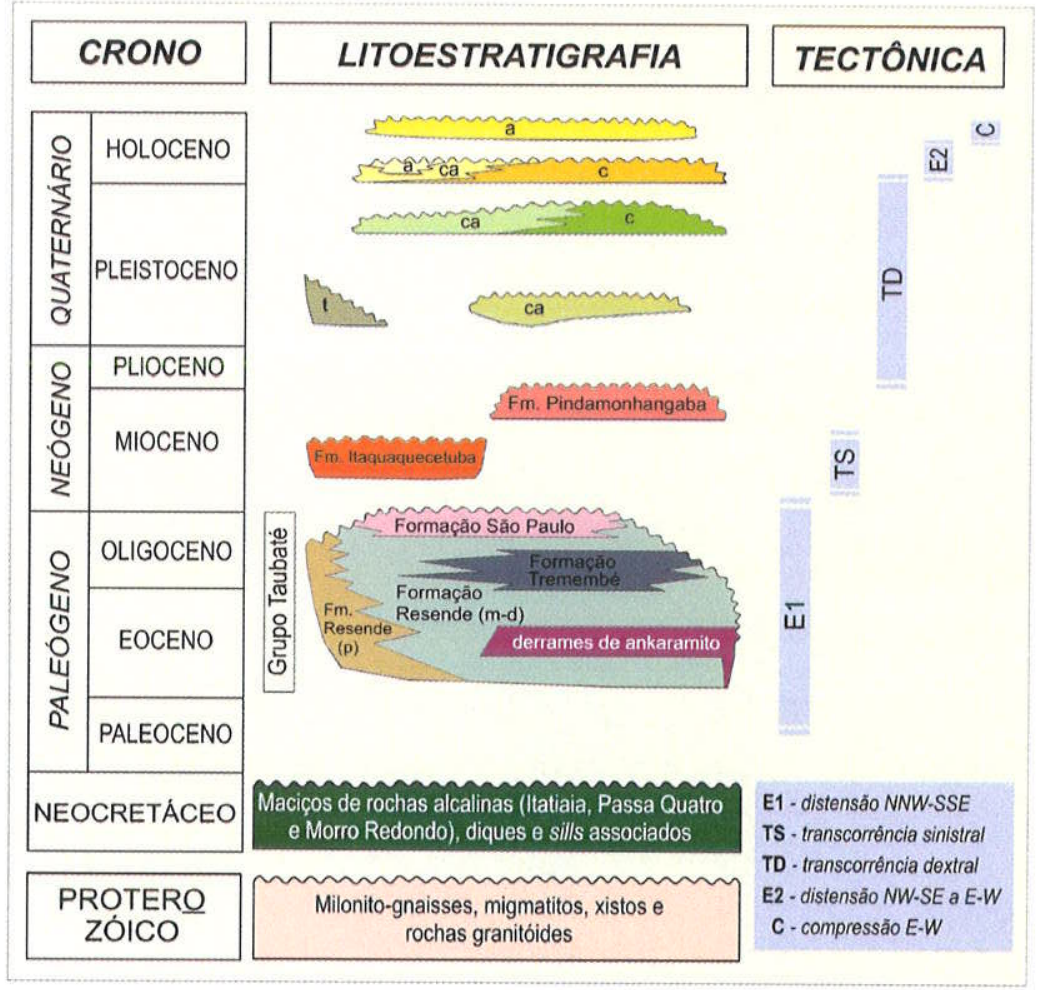

Figura 23 - Quadro litoestratigráfico e evolução tectônica na porção central do Rift Continental do Sudeste do Brasil. Extraído de Riccomini et al. (2004).

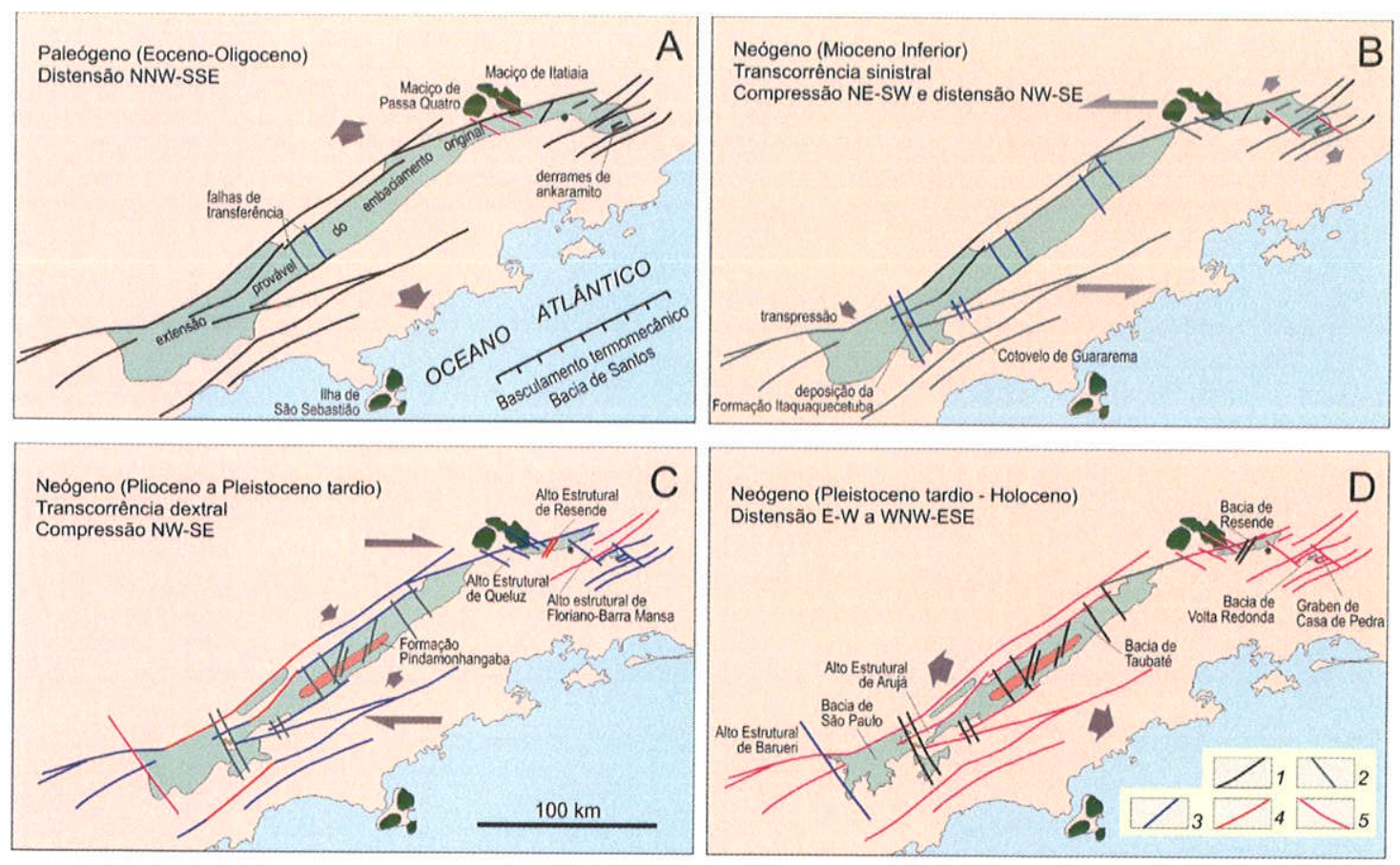

Figura 24 - Esboços paleotectônicos da evolução do Rift Continental do Sudeste do Brasil - Legenda no quadro D: 1) falhas de componente predominante normal; 2) falha de componente transcorrente sinistral; 3) falha de componente transcorrente destral; 4) falha de componente predominantemente inversa; 5) falha com movimentação não caracterizada. Fonte: modificado de Riccomini (1989) e Riccomini et al. (2004). 
O primeiro evento deformador teria ocorrido durante o Mioceno (e possivelmente final do Oligoceno), e seria responsável por falhas transcorrentes, originando bacias de afastamento (depocentros da Formação Itaquaquecetuba) e falhas de empurrão, estas colocando o embasamento sobre sedimentos cenozóicos, além de dobras cônicas observadas em folhelhos da formação Tremembé, na região central da Bacia de Taubaté (Riccomini 1989). O campo de esforços compreenderia um esforço horizontal máximo (SHmáx) com direção NE-SW, fato observado por Fernandes da Silva (1998) em falhas transcorrentes sinistrais WNW e E-W, na região entre as cidades de Pilar do Sul e Votorantim, Estado de São Paulo. Esse mesmo regime de esforços possivelmente foi responsável pelo soerguimento de blocos que gerou o Alto Estrutural de Queluz e a consequente individualização das bacias de Taubaté e Resende (Salvador, 1994).

O segundo evento deformador seria caracterizado por transcorrência destral com SHmáx de direção NW-SE, que seccionaria depósitos coluviais e colúvio-aluviais pleistocênicos (Riccomini 1989, Salvador \& Riccomini 1995, Riccomini et al. 2004)

O terceiro evento deformador teria ocorrido na passagem do Pleistoceno para o Holoceno. Nele, teria ocorrido o embutimento tectônico de depósitos de baixos terraços e coluviais em grabens de direções gerais NNE (Salvador \& Riccomini, 1995), a reativação de falhas normais de direção NE que afetaram o embasamento alterado e depósitos colúvio-aluviais holocênicos próximos à Zona de Cisalhamento Paraiba do Sul (Silva, 2011). Esse evento é relacionado a um regime distensivo de orientação geral E-W a ESE-WNW.

Salvador (1994) observou, na região do Vale do Paraíba, famílias conjugadas de juntas NE a ENE - NW a WNW e falhas que afetam depósitos coluviais, colúvioaluviais e aluviais holocênicos. A autora determinou um campo de paleoesforços de caráter compressivo, de direção E-W, relacionando-os a dados sismológicos de Assumpção (1992), e corresponderiam ao campo de esforços atual. Fernandes da Silva (1998) considerou que juntas conjugadas de direções ENE a NE - WNW a NW em granitóides e rochas metacarbonáticas maciças por ele observadas na região entre Pilar do Sul e Votorantim estariam possivelmente associadas a esses mesmos esforços compressivos de direção E-W.

Esses três últimos regimes de esforços neotectônicos também foram reconhecidos no Planalto de Campos do Jordão (Hiruma 1999, Hiruma et al. 2001), sobre a ZCJ. Nesta região foram observados depósitos falhados com idade 
aproximada de $18.580 \pm 140$ anos antes do presente relacionados à transcorrência destral, falhas normais em horizontes húmicos datados entre $9.250 \pm 170$ e $8.630 \pm 80$ anos indicando distensão E-W, e falhas de empurrão afetando colúvios com idade obtida de $3.410 \pm 80$ anos reativadas em campos de esforços compressivos $E-W$.

A evolução de estudos e o mapeamento de grandes estruturas, principalmente na porção oriental do país, bem como o desenvolvimento da Sismologia no Brasil, a partir da década de 1970, foram impulsionados pela necessidade de implantação de usinas nucleares e reservatórios ligados a grandes hidrelétricas. Hasui et al. (1978) e Hasui \& Ponçano (1978) consideraram uma possível relação entre a sismicidade natural e zonas de fraqueza apresentadas como geossuturas, além da provável correlação entre um sismo ocorrido naquela mesma década e a Falha de Itapeuna. Buscando a relação entre estruturas pré-cambrinas e suas reativações ao longo da história geológica, Hasui et al. (1982) delimitaram zonas sismogênicas de interesse às centrais nucleares da praia de Itaorna (Angra dos Reis, RJ).

Ao longo da década de 1990, a sismologia auxiliou na elaboração de estudos relacionados a campos de esforços intraplaca, principalmente na porção oriental da Plataforma Sul-Americana. Com o objetivo de testar mecanismos focais de pequenos terremotos no sudeste do Brasil, Assumpção (1998) elaborou modelos teóricos de esforços que mostraram concordância com esforços horizontais máximos de direções próximas a $E-W$, relacionados regionalmente ao empurrão causado pela abertura na Cordilheira Meso-Atlântica (ridge-push) e o puxão exercido pelo torque relacionado ao limite oeste da placa Sul-Americana, além de possiveis interferências de menor magnitude no contato superior da astenosfera (Assumpção 1992, Coblentz \& Richardson 1996).

A figura 26 mostra a localização dos epicentros de inúmeros eventos sísmicos no sudeste do Brasil, obtidos por relatos históricos e sismógrafos. Esses dados, compilados em um mapa interativo pelo Instituto de Astronomia, Geofísica e Ciências Atmosféricas (IAG), da Universidade de São Paulo, marcam terremotos em cinco intervalos entre os anos de 1720 e 2010. 


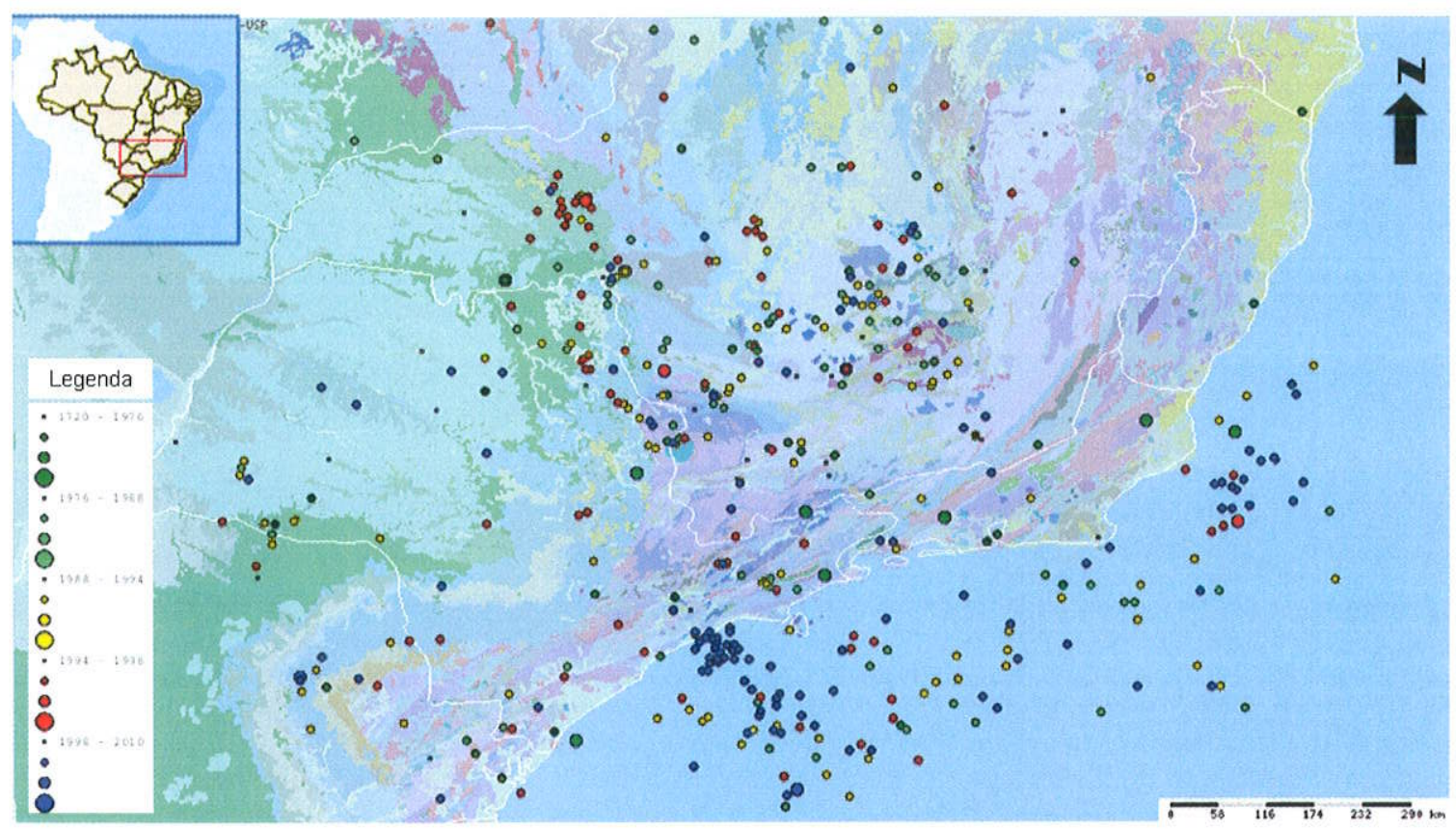

Figura 25 - Mapa de Sismicidade do Sudeste do Brasil em escala 1 : 5.000.000. Modificado de IAG 2011.

O controle do comportamento geotectônico da Plataforma Brasileira, em especial da porção oriental do sudeste do Brasil, está intimamente ligado a dinâmica litosférica e esforços intraplaca, que estão ativos atualmente e são responsáveis pela configuração geológica dos terrenos, demonstrando, portanto, uma importante zona de fraqueza limitada por feixes de estruturas rúpteis reativadas sucessivas vezes, como observado por Saadi (1993) para a atividade neotectônica da região.

A tectônica quaternária indica essa estreita relação entre estruturas geológicas, anomalias do geóide, soerguimentos, estruturas de liquefação e reativação de falhas seccionando depósitos sedimentares recentes com dados sísmicos e modelos teóricos de esforços (Riccomini \& Assumpção 1999). Vários autores tem reconhecido que esforços intraplaca continuam a atuar até o presente na região sudeste do Brasil (e.g. Assumpção 1992), produzindo deformações em grande parte relacionadas geograficamente às zonas de cisalhamento antigas (Saadi 1993, Salvador \& Riccomini 1995, Hiruma 1999), prováveis evidências de processos de reativação tectônica. Neste contexto, a ZCJ, objeto de estudo dessa dissertação, é de grande relevância para a compreensão da evolução dos campos de esforços vigentes no sudeste do Brasil durante o fanerozoica. 


\section{A ZONA DE CISALHAMENTO JUNDIUVIRA}

A Zona de Cisalhamento Jundiuvira foi descrita por Hasui et al. (1969). Segundo os autores, esta estrutura é muito característica no limite sul dos corpos granitóides, como o de Terra Nova, na região de Franco da Rocha, por observações de lineamentos em aerofotos na Serra dos Cristais, e até a região de Itu, onde controla a estrutura do Vale do Rio Jundiuvira. Esse mesmo trabalho mostra que a Falha de Itu apresenta uma aparente relação com a de Jundiuvira, com a qual é paralela, no flanco norte da Serra do Guaxatuba, controlando possivelmente o Rio Tietê nas imediações da rodovia Jundiaí - Itu.

Posteriormente, com a evolução de trabalhos de mapeamentos, caracterizando diferentes terrenos e seus limites em zonas de falhas ou suturas, a estrutura foi estendida para leste e nordeste, inicialmente para a região de Piracaia (Cavalcante \& Kaefer 1974) e Serra do Mato Mole (Algarte 1974), posteriormente, até a região de Delfim Moreira (Hasui et al. 1977) e a região do Pico do Itapeva, na Serra da Mantiqueira, a sudeste de Campos do Jordão, SP (Cavalcante et al. 1979). Esse mesmo traçado já havia sido proposto por Hasui et al. (1978), que indicaram a persistência da descontinuidade pelo sopé da Serra da Mantiqueira, seguindo sentido à região de Passa Quatro, MG.

A ZCJ apresenta geometria suavemente ondulada, com direção média ENE-WSW, e inflexões para E-W. . Em esboços regionais (figura 27) esta estrutura compartimenta diferentes domínios tectônicos (nappes inferiores do Orógeno Brasília, Terreno São Roque do Orógeno Apiaí-Paranapiacaba e Domínio Andrelândia do Orógeno Ribeira). 


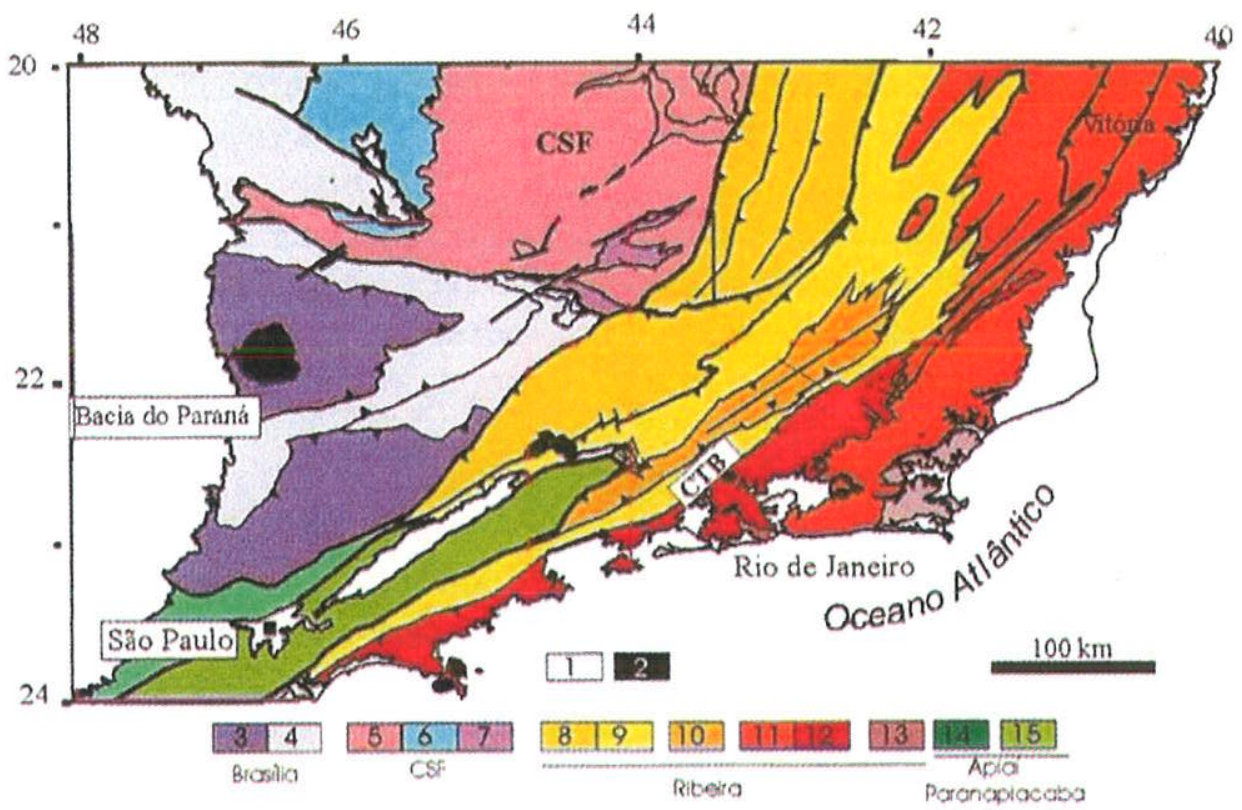

Figura 26 - Mapa tectônico do segmento central do Sistema Orogênico Mantiqueira. 1) Rifts Cenozóicos; 2) Rochas Alcalinas do Cretáceo e Terciário; 3) e 4) Orógeno Brasília: 3 - Nappes Inferiores e 4 - Nappes Superiores; 5) Embasamento do Craton do São Francisco e Domínio Autóctone; 6) Super Grupo São Francisco; 7) Metassedimentos do Domínio Autóctone; 8) a 13) Orógeno Ribeira: 8 - Domínio Andrelândia, 9 - Domínio Juiz de Fora, 10 - Kipple Paraíba do Sul, 11 - Terreno oriental, 12 - Granitóides do Arco Magmático Rio Negro, 13 - Terreno Cabo Frio; 14) e 15) Orógeno Apiaí-Paranapiacaba: 14 - Terrenos São Roque e Açungui, 15 - Terreno Embu. Modificado de Heilbrom et al. (2004).

No Mapa Geológico do Estado de São Paulo (CPRM 2006) a ZCJ é mapeada por quase $300 \mathrm{~km}$ de extensão no Estado de São Paulo, e aparentemente nivela blocos ou terrenos crustais com naturezas geológicas distintas.

A figura 28 apresenta o traçado da estrutura sobre modelo digital de elevação sobreposto ao mapa de relevo sombreado. 


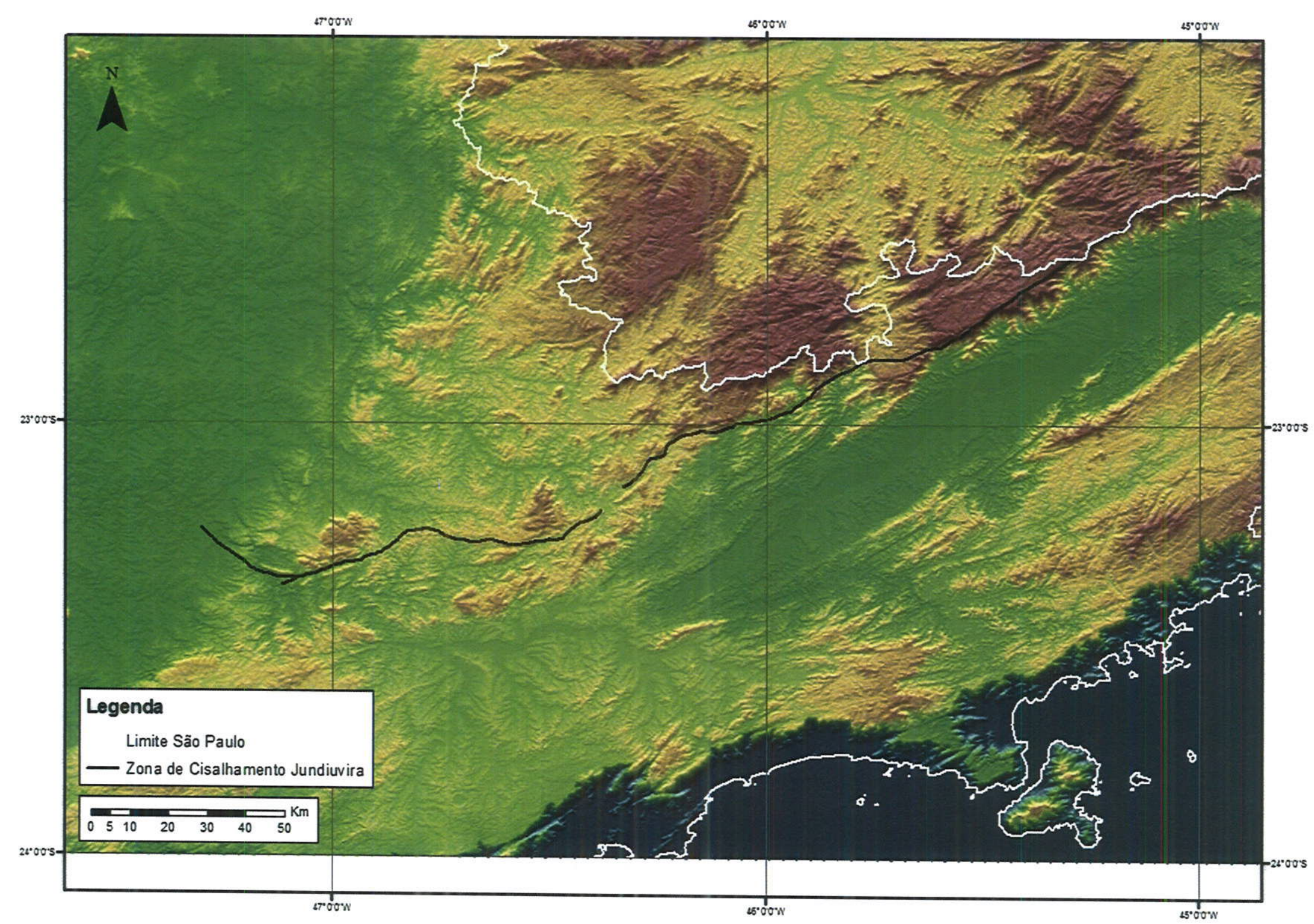

Figura28-ZCJ em modelo digital de elevação do leste do Estado de São Paulo. 
A interferência dessa megaestrutura, assim como outras de mesma natureza estrutural no sudeste do Brasil, em terrenos pré-cambrianos do embasamento, bem como seu retrabalhamento de natureza dúctil e dúctil-rúptil, vem sendo estudada por diversos autores. Hackspacher \& Godoy (1989) definiram a Zona de Cisalhamento Itu-Jundiuvira como tendo sido gerada sob regimes dúcteis, transcorrentes destrais durante $\circ$ Brasiliano. Essa caracterização é feita por Hasui et al. (1975), descrevendo o caráter transcorrente destral para diversas falhas, a chamada "Zona de Transcorrência São Paulo". De fato, no Estado de São Paulo, foram descritas superposições destrais em zonas de cisalhamento e suas implicações para os terrenos por elas afetados (Garcia \& Campos Neto 1997, Campanha 2002).

Entretanto sua evolução mais recente, mesozóico-cenozóica, gerou falhas rúpteis de reativação ao longo da zona de cisalhamento, que necessitam melhor caracterização. Pesquisas realizadas na Serra da Mantiqueira, mais especificamente no Platô de Campos do Jordão, revelaram inúmeras reativações afetando divisores de água, depósitos coluviais, stone-lines e basculamento de blocos (Hiruma 1999, Modenesi-Gauttieri et al. 2002).

Desde seu reconhecimento e descrição efetuado por Hasui et al. em 1969, a feição foi caracterizada e mapeada em diferentes escalas. A figura 29 ilustra uma compilação com diferentes trabalhos ao longo de toda estrutura, com variações provavelmente relacionadas às diferentes escalas de mapeamento, erros acumulados na confecção de mapas ou, ainda, diferentes interpretações durante $\circ$ mapeamento. Grandes estruturas rúpteis caracterizadas como splays ou mesmo a zona de milonitização resultante do cisalhamento marcam desvios laterais na localização dos limites da feição. 

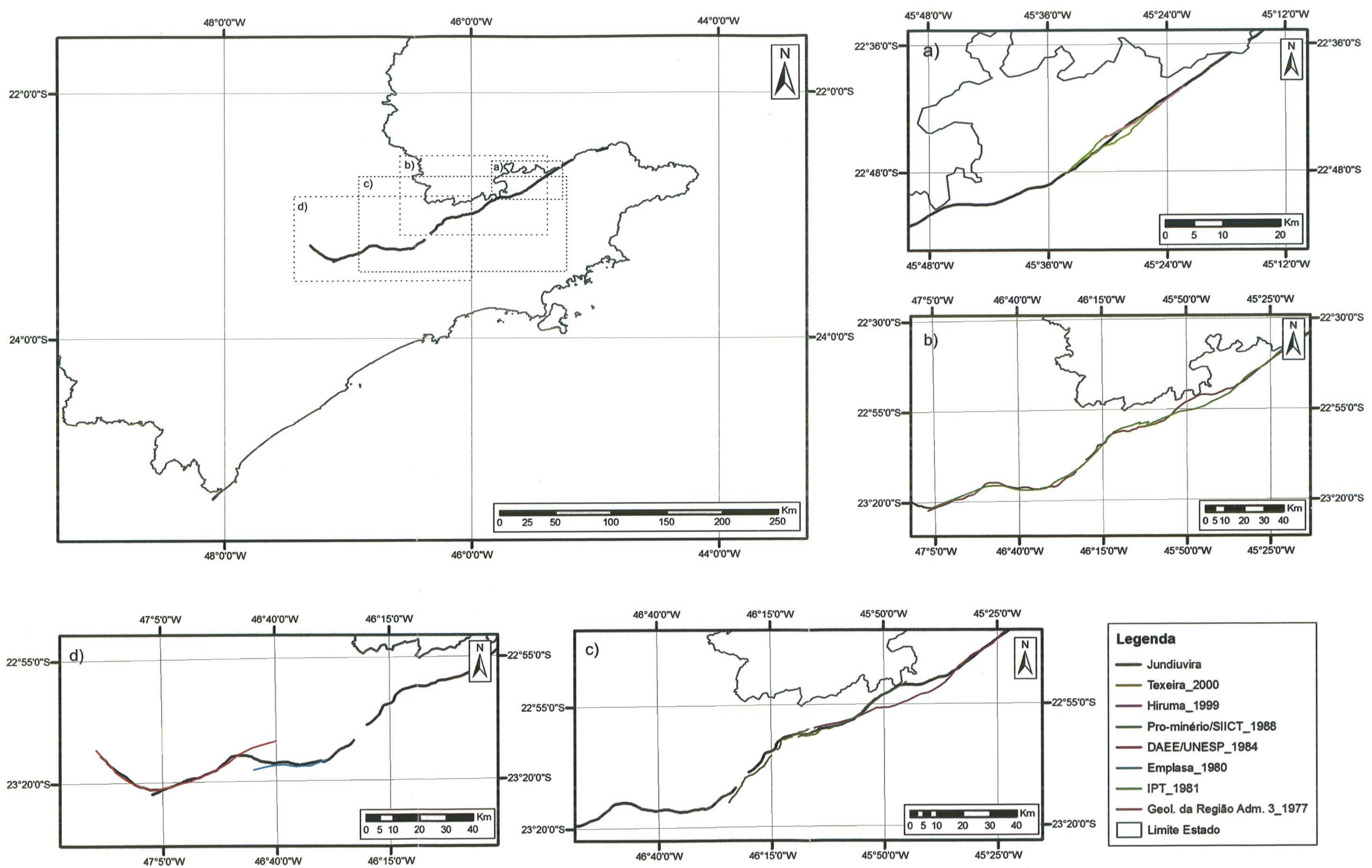

Figura 29 - Mapa temático ilustrando as diferenças entre os traçados para a ZCJ adotada neste trabalho (CPRM 2006) e estudos anteriores. a) Teixeira (2000) e Hiruma (1999); b) IPT (1981); c) Pró-Minério/SIICT (1988) e Geologia da Região Administrativa 3 (1977); d) DAEE/UNESP (1984) e EMPLASA (1980). Os retângulos alfabeticamente identificados referem-se aos detalhes no mapa regional. 
Como ferramenta de auxílio na determinação de um traçado contínuo para a ZCJ, foi produzido o modelo digital de elevação, com o qual foram gerados mapas de relevo sombreado e utilizados diferentes posições de iluminantes. Os mapas de relevo sombreado e a utilização de diferentes posições de iluminantes objetivam ressaltar caracteristicas morfológicas, muitas vezes relacionadas às grandes estruturas tectônicas (figuras 30 e 31).

Os iluminantes, elevados a $30^{\circ}$ e localizados a norte, sul, noroeste e sudeste, mostraram feições pronunciadas, principalmente nas regiões próximas á Cidade de Itu, no extremo sudoeste do traçado da ZCJ, e ao longo da escarpa da Serra da Mantiqueira, na sua parte nordeste, tendo uma aparente continuidade para o Estado de Minas Gerais. 


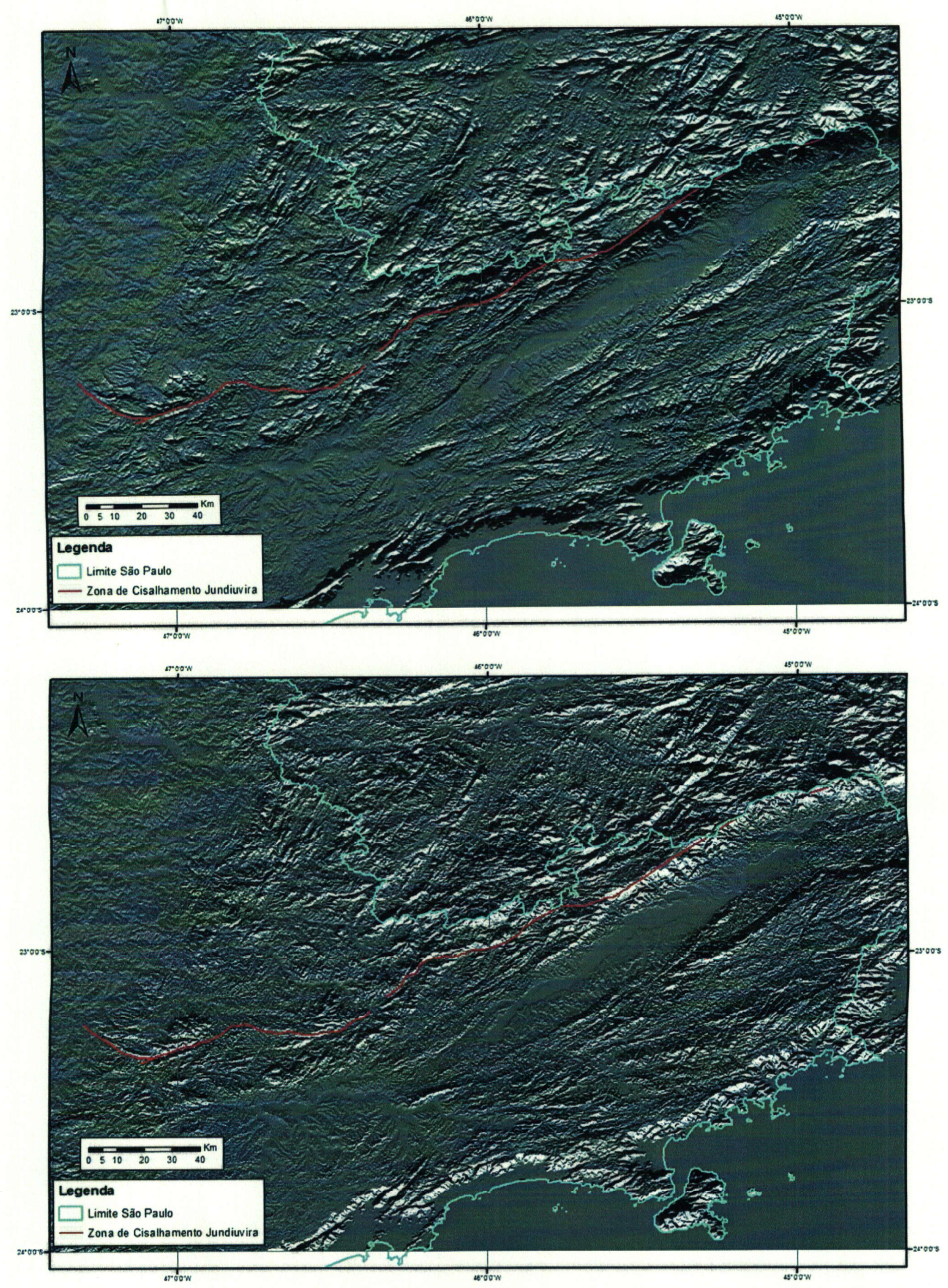

Figura 30 - Mapa de relevo sombreado com destaque para a ZCJ. Os iluminantes estão posicionados em norte e sul, respectivamente, com $30^{\circ}$ de elevação. 

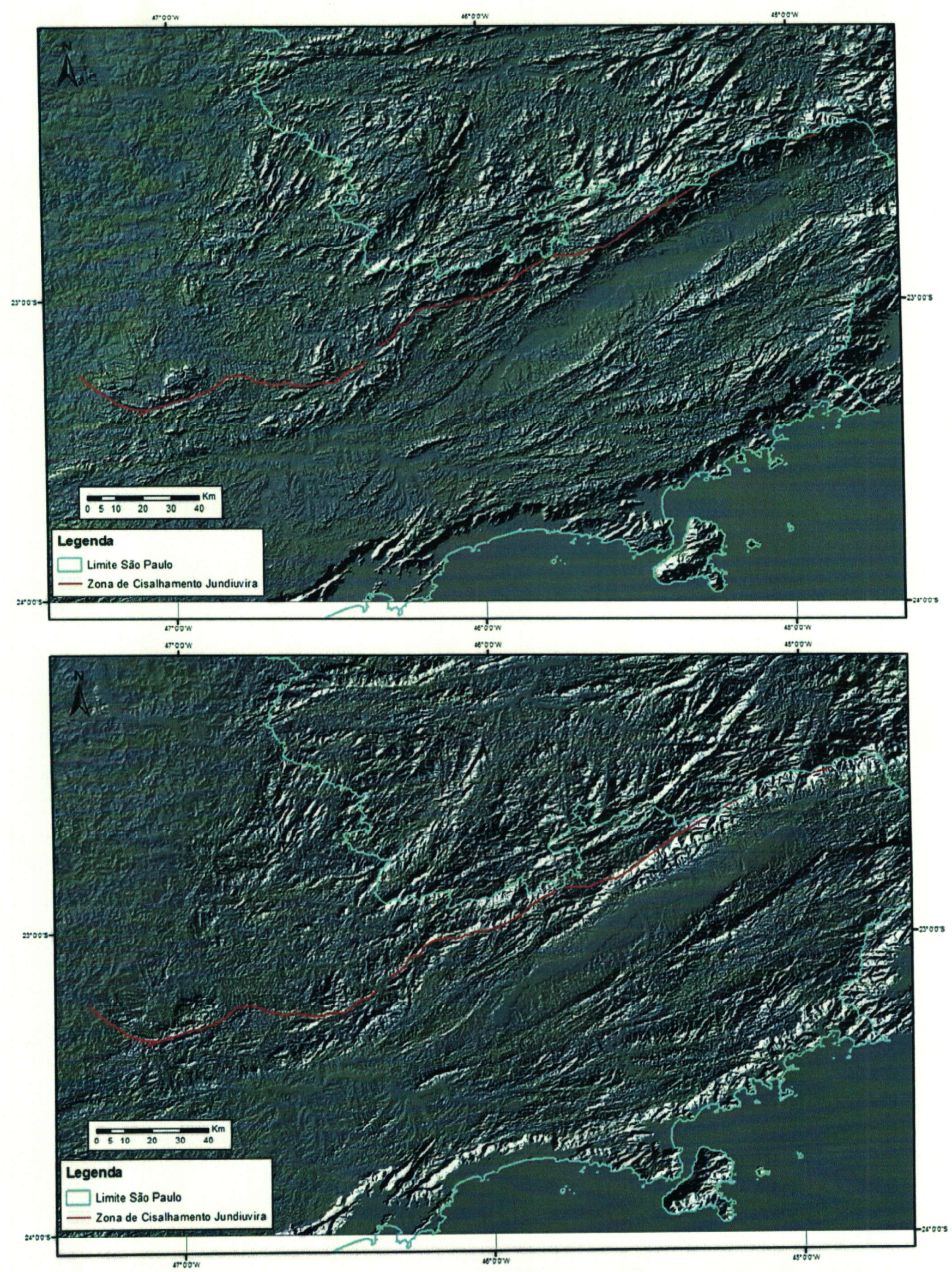

Figura 31 - Mapa de relevo sombreado com destaque para a ZCJ. Os iluminantes estão posicionados em noroeste e sudeste, respectivamente, com $30^{\circ}$ de elevação. 


\section{REATIVAÇÃO FANEROZOICA DA ZONA DE CISALHAMENTO JUNDIUVIRA}

A presente dissertação tem como proposta a descrição e investigação de estruturas tectônicas desenvolvidas ao longo da ZCJ, bem como correlacioná-las a reativações ocorridas durante o fanerozoica.

A caracterização dessas estruturas e a análise cinemática devem ser temporalmente limitadas, quando possível, por marcadores estratigráficos.

Foram investigadas cinco regiões ao longo do traçado da zona de cisalhamento, com diferentes idades, naturezas litológicas e evoluções tectônicas.

Essas regiões abrigam diferentes ambientes geológicos, a saber: depósitos neopaleozoicos do Grupo Itararé; granitóides pós-orogênicos da Provincia Granítica Itu; sedimentos quaternários sobre embasamento précambriano no Planalto de Campos do Jordão; depósitos metassedimentares do estágio de transição Ediacarano-Cambriano da Bacia do Pico do Itapeva; e diques de rochas alcalinas neocretáceos do Maciço Alcalino de Passa Quatro.

Para a descrição e análise dos campos de esforços vigentes no ao longo da ZCJ, as regiões foram ordenadas pelo caráter puramente geográfico, oeste para leste.

\subsection{ROCHAS SEDIMENTARES DO GRUPO ITARARÉ}

\subsubsection{INTRODUÇÃO}

O Grupo Itararé representa os registros glaciais do intervalo entre o neocarbonífero e eopermiano da Bacia do Paraná. Segundo França \& Potter (1988), o Grupo Itararé abrange três grandes ciclos de sedimentação, com variações granulométricas importantes da base para o topo em cada unidade, denominados formações Lagoa Azul, Campo Mourão e Taciba, temporalmente correlacionáveis aos arenitos avermelhados da Formação Aquidauana (Zálan et al. 1990) (figura 32). 


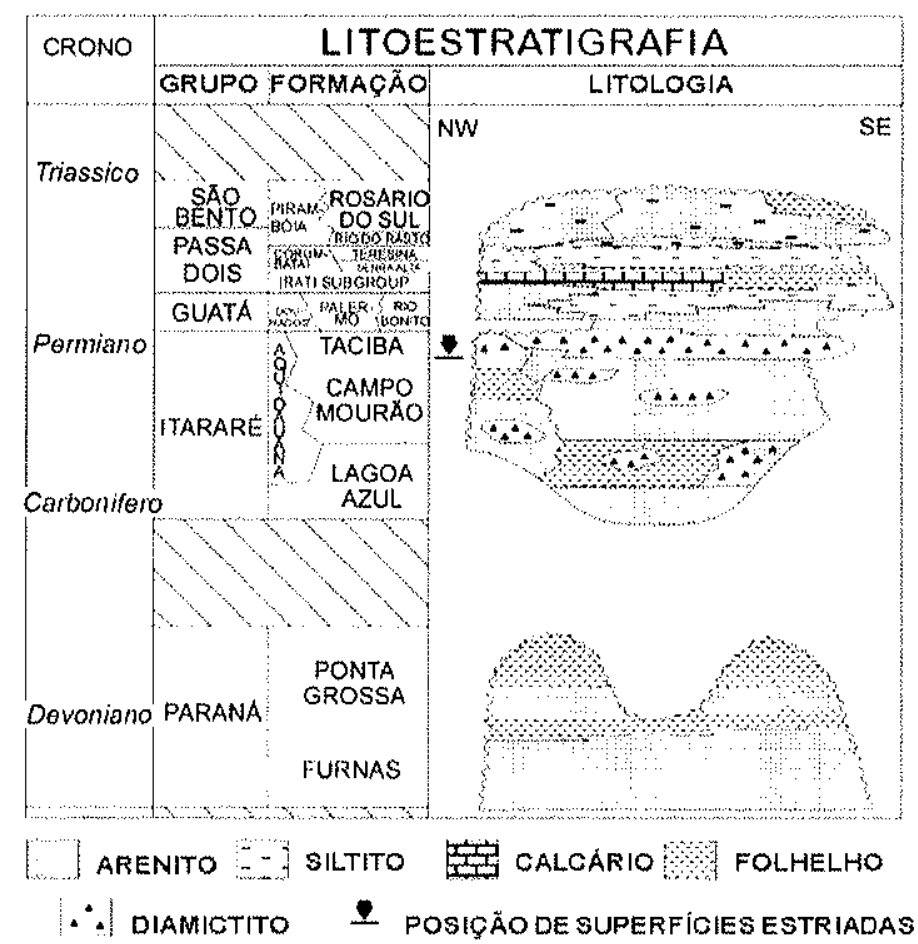

Figura 30 - Coluna litoestratigráfica esquemática da seção paleozóica da Bacia do Paraná. Extraido de Gesicki et al. (2002), modificado de França \& Potter (1988).

\subsubsection{CONTEXTO TECTONNICO LOCAL}

Exposições de rochas sedimentares do Grupo Itararé na faixa de afloramentos da porção leste da Bacia do Paraná no Estado de São Paulo exibem numerosas e diferenciadas estruturas de deformação invariavelmente relacionadas à glaciação, como produtos de atividades glaciotectônicas ou como feições de abrasão intraformacionais ou em rochas sotopostas aos depósitos. As descrições disponiveis sobre pavimentos estriados relacionados à glaciação neopaleozoica na Bacia do Paraná mostram um sentido geral de deslocamento do gelo no rumo N-NNW, com geleiras provenientes da região atualmente situada no sudoeste da África (e.g. Gesicki et al. 2002).

Rocha Campos et al. (2000) descreveram estruturas graciotectônicas neopaleozoicas na região de Cerquilho, Estado de São Paulo. As deformações são intraestratais, em uma camada com espessura métrica ( 3 a $4 \mathrm{~m}$ ), com pequenas feições rúpteis, dobras de arrasto e dobras ligadas a magnitudes deformacionais diferentes, separadas por uma material mais resistente, no caso um clasto métrico de granito. Segundo os autores, as feições observadas 
mostram uma direção de compressão NNW-SSE, e o sentido do transporte do gelo para NNW (figura 33).

A figura 34 é uma compilação do sentido de feições de abrasão geradas pelo deslocamento de geleiras de SSE para NNW, principalmente sobre substrato inconsolidado.

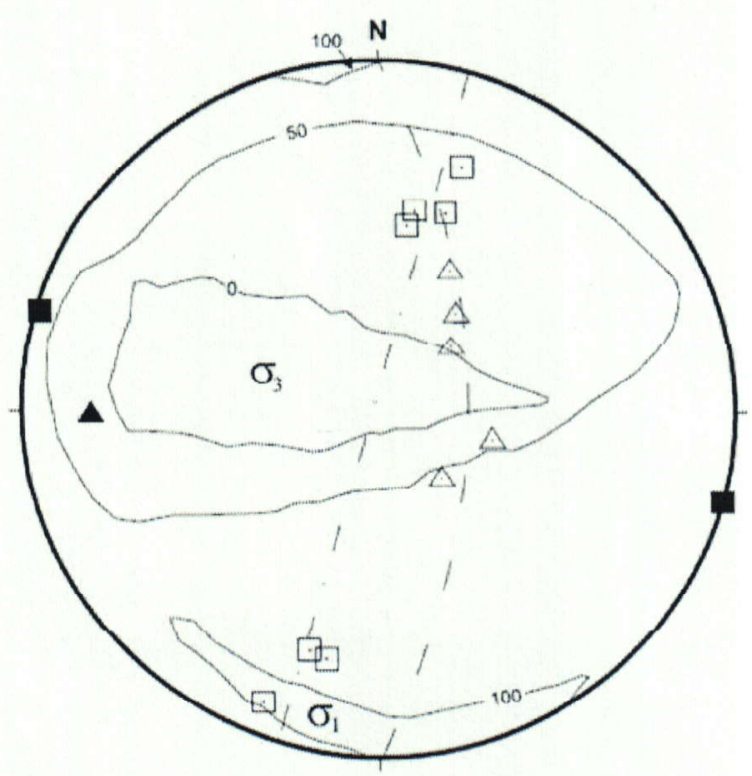

Figura 31 - Indicação do campo de esforços para as estruturas observadas em Cerquilho, SP. Quadrados brancos e pretos são referentes a pólos e eixos de dobras de arrasto, respectivamente; triângulos brancos e pretos são pólos e eixos de dobras anticlinais, respectivamente. Extraído de Rocha Campos et al. (2000). 


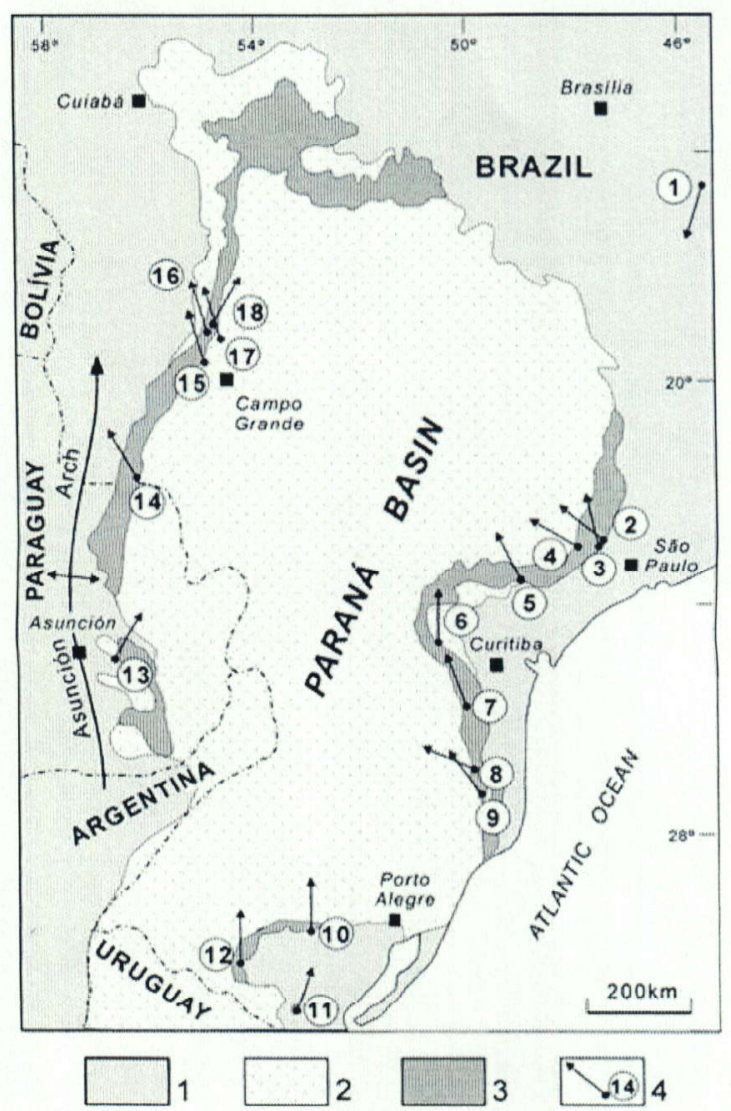

Figura 32 - Compilação com as principais localidades e sentidos de superfícies de abrasão na Bacia do Paraná. Extraído de Gesicki et al. (2002), modificado de Riccomini \& Velázquez (1999).

\subsubsection{DEFORMAÇÃO RÚPTIL EM ROCHAS DO GRUPO ITARARÉ NA REGIÃO DE ITU.}

A influência das zonas de Cisalhamento de Jundiuvira e Itu em rochas metamórficas e graníticas da região de Itu é reconhecida desde o trabalho de Hasui et al. 1969). Com anteriormente ressaltado, deformações em rochas sedimentares do Grupo Itararé, tais como falhas e dobras, tem sido relacionadas à glaciotectônica (v.g. Rocha Campos et al. 2000).

Neste trabalho procurou-se verificar a influência da Zona de Cisalhamento de Itu nas rochas do Grupo Itararé. Para tanto foi selecionada uma cava de extração de folhelho empregado na fabricação de tijolos. O local, uma olaria, está situado nas coordenadas UTM 0261591, 7428918, zona 23K, 
no Município de Itu, Estado de São Paulo. A área foi selecionada com base na sua posição em relação à ZCJ, verificada a partir dos mapas geológicos do Estado de São Paulo, CPRM (2006), escala 1:750.000 e DAEE/UNESP (1984), escala 1:250.000, folha São Paulo.

As observações foram realizadas no pavimento e em corte subvertical da cava. Neste local, na parte inferior da exposição, ocorrem folhelhos, normalmente de cor cinza, empastilhados, algumas vezes intercalados com finas camadas de arenitos finos de cor cinza clara a branca. Alguns clastos caídos, de dimensões até métricas, predominantemente de granitos, foram observados em meio à matriz. Na parte superior ocorrem diamictitos de origem glacial sobrepostos aos folhelhos.

A expectativa inicial era a de, que ao menos em parte, as deformações fossem sin-sedimentares e de origem tectônica, o que permitiria estabelecer a idade e eventualmente os campos de esforços vigentes no permocarbonifero. No local foram observadas falhas normais de diferentes gerações, falha de empurrão e dobras. Entretanto, todas as estruturas são pós-sedimentares, e afetaram rochas sedimentares já litificadas. A figura 35 apresenta a relação entre as inúmeras falhas encontradas, onde foi possivel hierarquizar seis familias de falhas de acordo com suas relações de corte. 


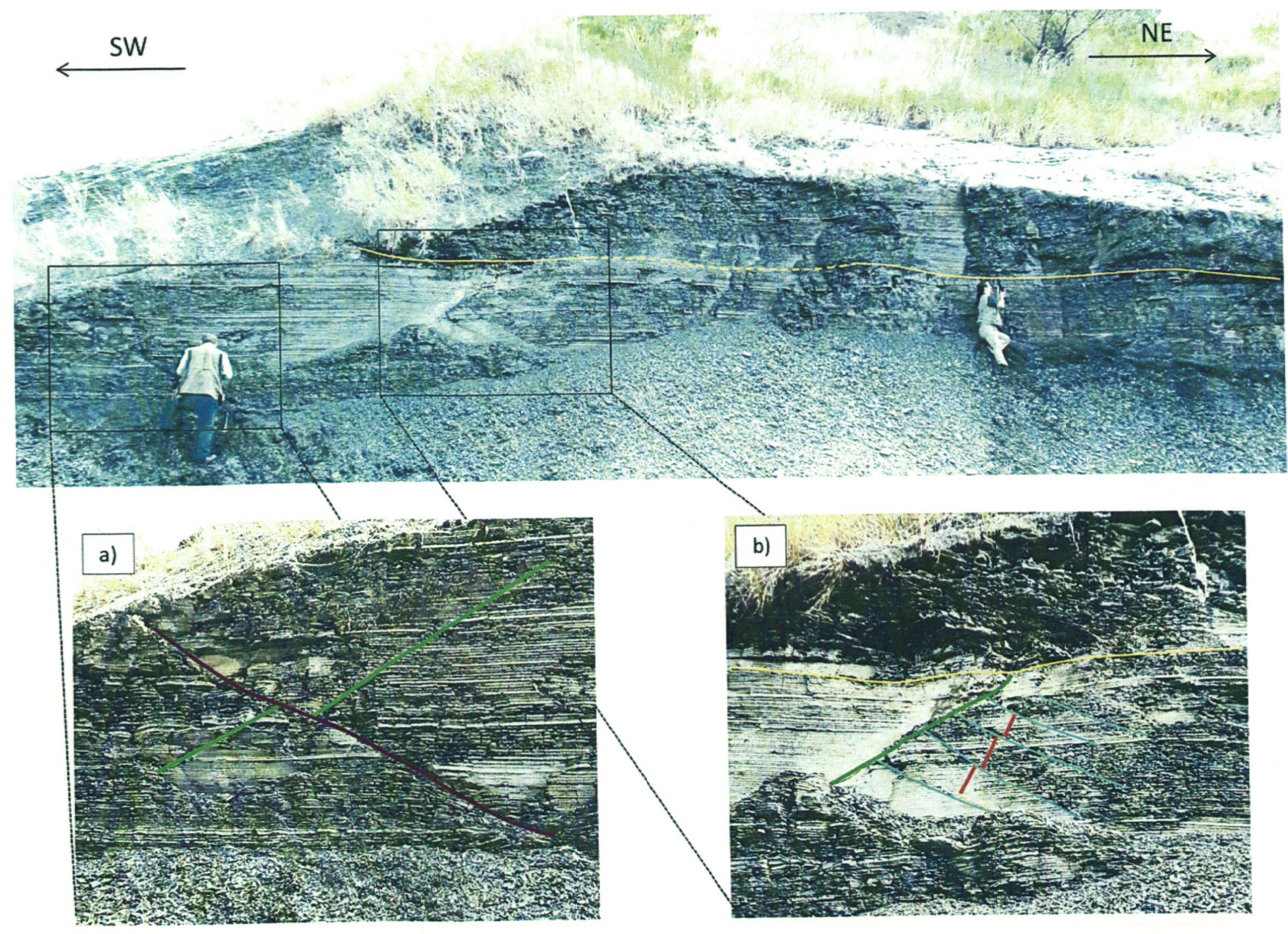

Figura - Hierarquização de familias de falhas por relação de corte em afloramento. As falhas mais representativas estão simbolizadas por cores. A primeira geração corresponde á linha vermelha, a segunda às linhas azuis, a terceira às linhas verdes, aquarta à linha roxa e a quinta geração pela linha alaranjada. 
Após a ordenação cronológica das diferentes familias de falhas, foram determinadas as suas naturezas, se normais, inversas ou transcorrentes, e obtidos dados pareados de atitudes de falhas e respectivas estrias de atrito (ou lineações de crescimento mineral), para determinação dos palecampos de tensões vigentes durante os seus deslocamentos.

$\mathrm{Na}$ parte inferior da exposição estudada, um corte vertical, os folhelhos do Grupo Itararé são sub-horizontais e exibem falhas com diferentes direções e mergulhos e relações de corte muito evidentes. As quatro primeiras famílias (em ordem cronológica) são de falhas normais, que mostraram que o esforço máximo $\left(\sigma_{1}\right)$ permaneceu inalterado e constantemente vertical. . A família $A$, mais antiga (figura 35), é representada por uma falha normal de direção WNWESE, com mergulho para SSW; a apresenta B falhas normais de direção NWSE a NNW-SSE, com mergulhos para NE a ENE; a $C$ falhas normais de direção NNW-SSE, com mergulhos para WSW; e a D é representada por uma falha normal de direção ENE-WSW com mergulho para NNW. As falhas das famílias $A, B$ e C são paralelas a subparalelas ao traço NW-SE da ZCJ na região. Em todos os casos as estrias são próximas à reta de maior declive (mergulho) do plano de falha, o que lhes confere caráter normal praticamente puro. Os eixos de esforços intermediário $\left(\sigma_{2}\right)$ e mínimo $\left(\sigma_{3}\right)$, mudaram de posição ao longo do tempo, sugerindo rotação horária, inicialmente com distensão NE-SW, até a posição ortogonal, com distensão NNW-SSE (figura 36). 

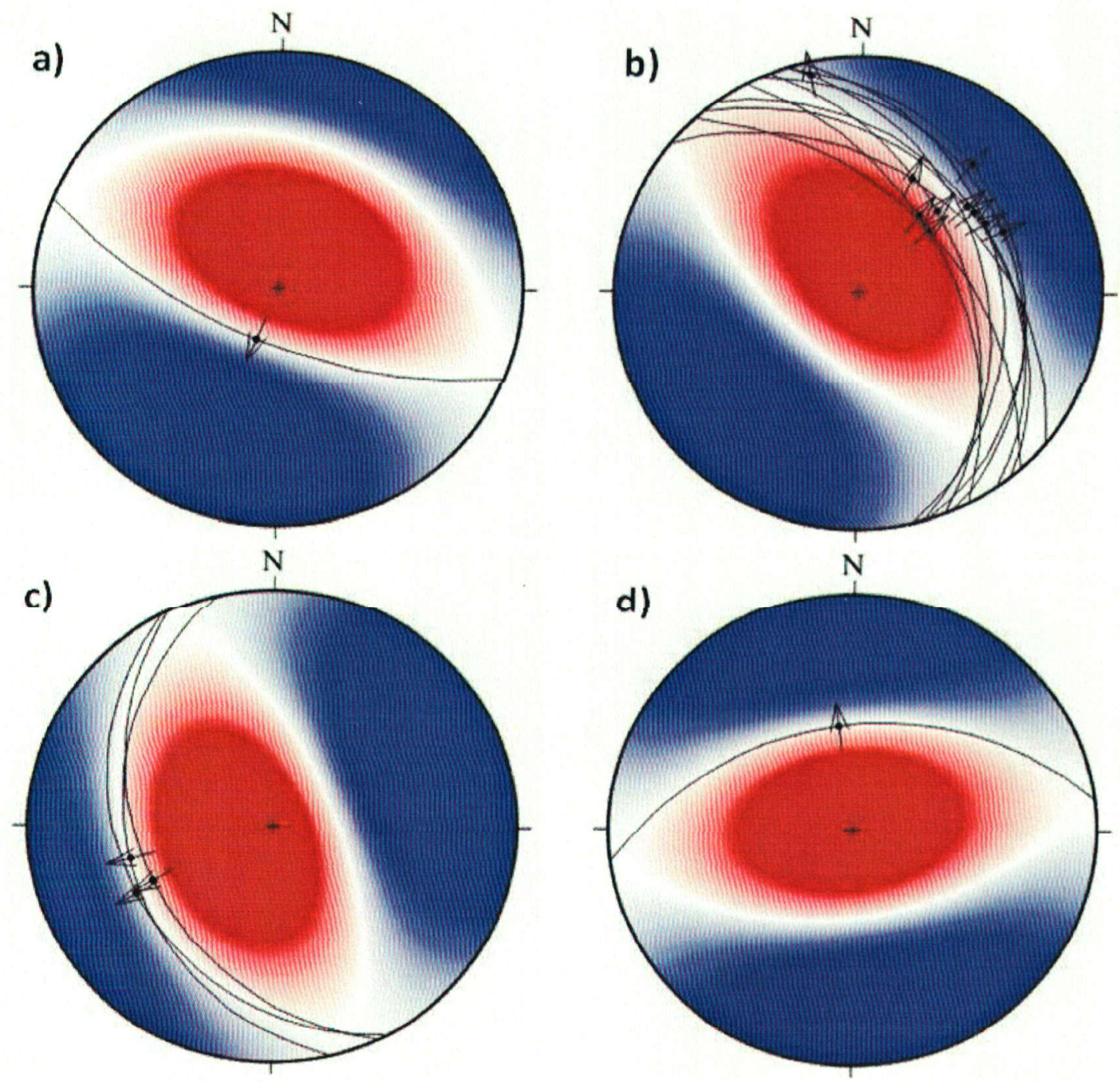

Figura 34 - Determinação do campo de esforços para as quatro primeiras famílias de fraturas hierarquizadas no Grupo Itararé. Notar 01 (campo em vermelho) constantemente vertical e rotação horária de o2 e $\sigma 3$ (campo em azul). 
Próximo ao topo do corte vertical, os folhelhos apresentam-se dobrados e em descontinuidade com o pacote inferior. Essa descontinuidade é marcada por uma superfície de grande continuidade lateral, ao longo da qual ocorre uma fina (milimétrica) película argilosa de cor preta, com estrias marcadas pelo deslocamento, caracterizada como "superfície de descolamento". Essa superfície interrompe falhas da familia $\mathrm{C}$ e apresenta mergulho sub-horizontal para NW. As estrias nela presentes indicam que o pacote superior, alóctone, foi transportado no sentido geral de noroeste para sudeste. Confirmando o sentido do transporte, dobras do mesmo pacote de folhelhos apresentam seus flancos de mergulho mais suave para NW e linha de charneira com atitude ortogonal a esse mergulho, na direção $\mathrm{NE}$, em posições sub-horizontais, com baixos mergulhos para NE. A soma dessas duas estruturas marcantes na exposição, somadas com uma falha inversa de direção $\mathrm{N}-\mathrm{S}$ e mergulho para $\mathrm{E}$, com indicadores cinemáticos formados por degraus de crescimento mineral (calcita), indicam, segundo o diagrama da figura 37, um esforço principal $\sigma_{1}$, subhorizontal, indicando transporte geral de NW para SE (figura 38).

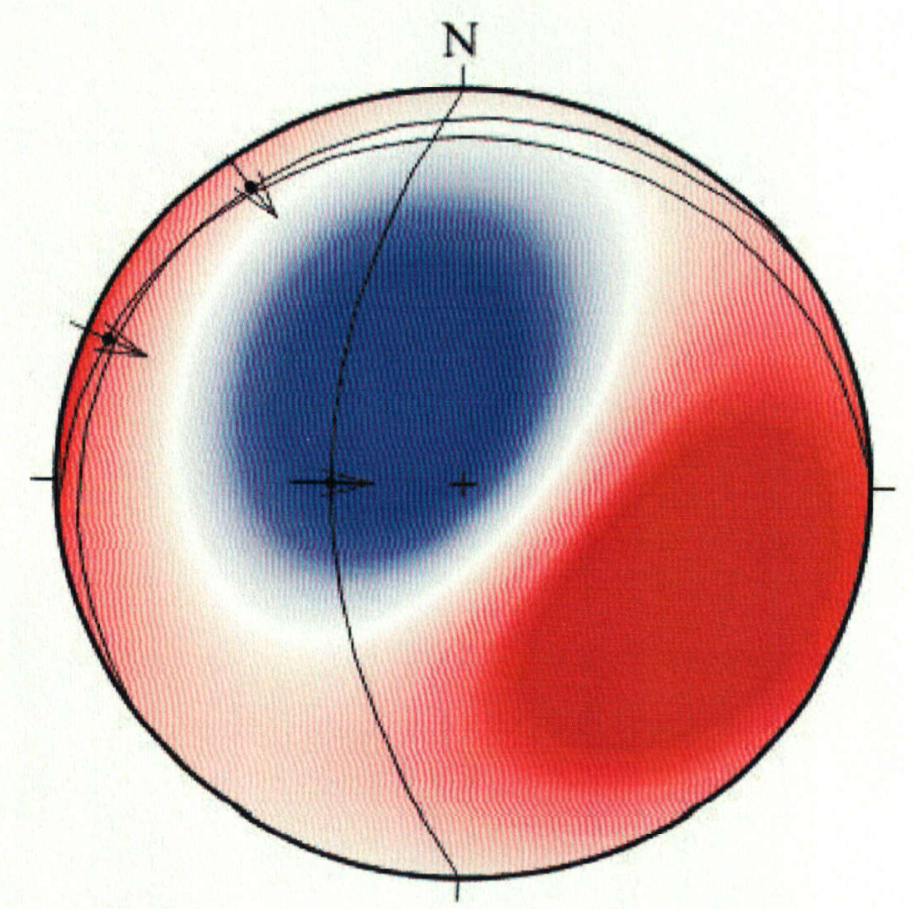

Figura 35 - Determinação do campo de esforços compressivos que condicionou a superfície de descolamento, dobras e falhas inversas, indicando transporte para SE. 

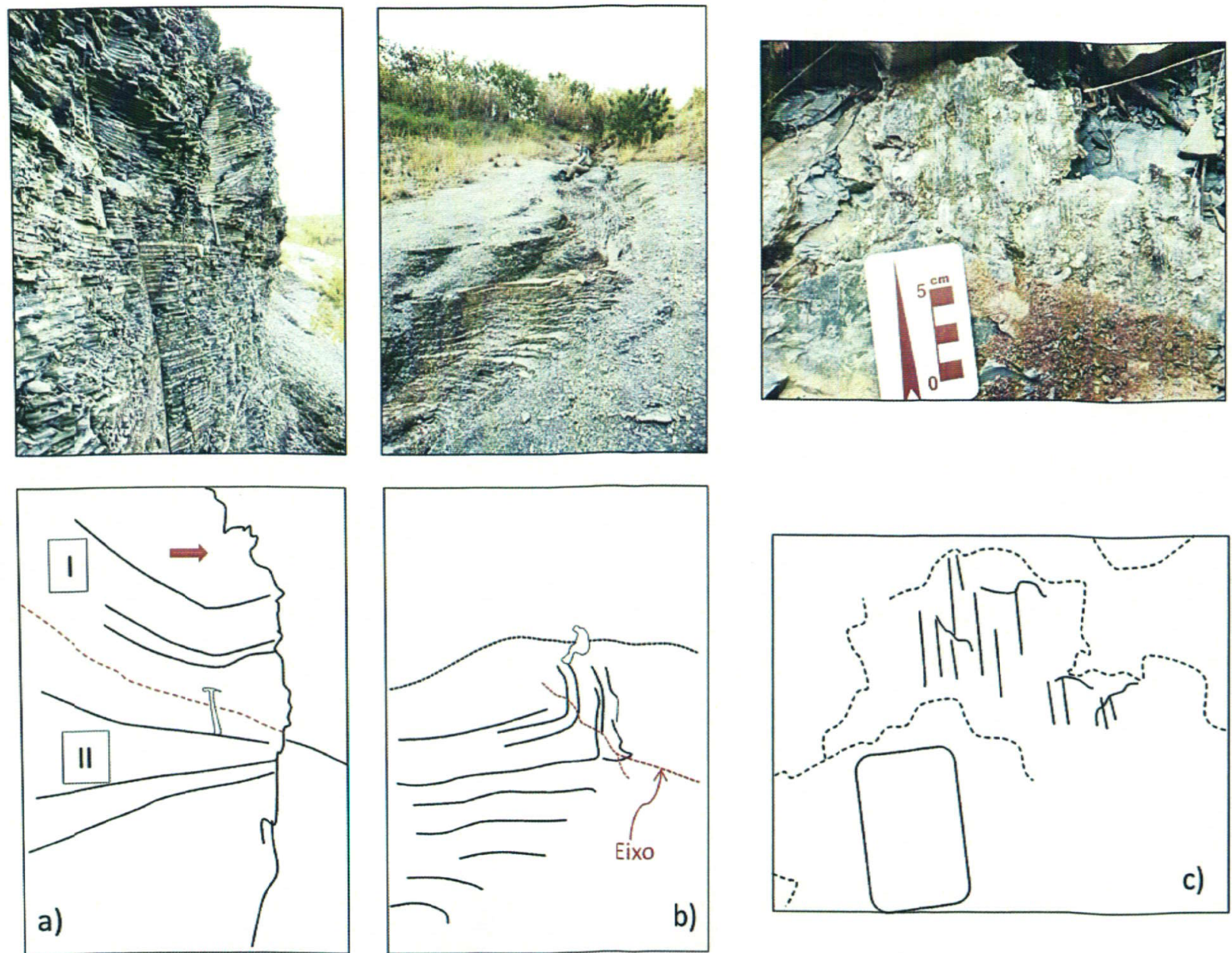

Figura - Estruturas que evidenciam o sentido de transporte (seta vermelha) do pacote superior de rochas sedimentares do Grupo ltararé: a) separação dos pacotes I $\mathrm{e}$ || pela superficie de descolamento destacada pela linha tracejada vermelha; b) dobra resultante da deformaçâa causada pelo transporte com plano axial e eixo marcado pela linha tracejada vermelha; c) falha inversa com indicadores cinemáticos formados por degraus de crescimentomineral. 
O último evento detectado é representado por falha que condiciona a frente vertical da exposição, com dezenas de metros de comprimento e cerca de $6 \mathrm{~m}$ de altura. O sentido de deslocamento da falha ficou registrado por estrias no corte das camadas centimétricas de areia fina, intercaladas com os folhelhos cinza. Os dados pareados indicam um campo de esforços com compressão máxima e mínima $\left(\sigma_{1}\right.$ e $\left.\sigma_{3}\right) \mathrm{N}-\mathrm{S}$, caracterizando movimentação lateral esquerda oblíqua, ou seja, regime transtrativo sinistral (figura 39 ).

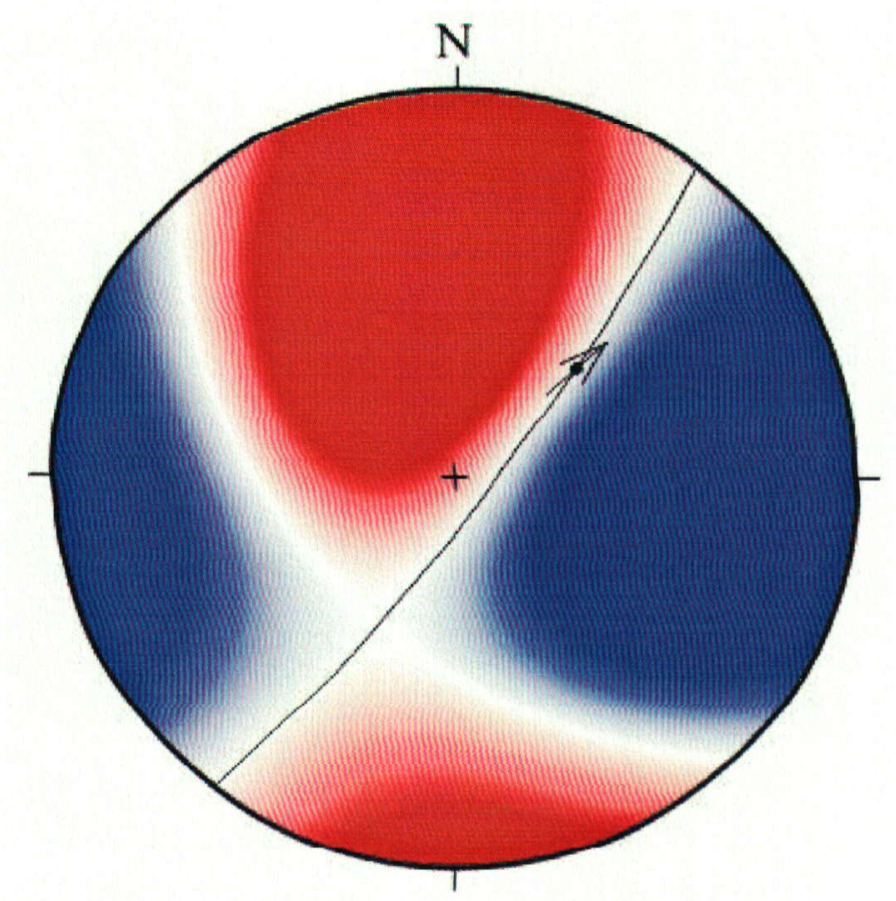

Figura 37 - Determinação do campo de esforços para a falha que condiciona a frente do afloramento e é a mais jovem das deformações estudadas no local. A cinemática é transcorrente sinistral com componente normal. 


\subsection{GRANITO PÓS-OROGÊNICO ITU}

\subsubsection{INTRODUÇÃO}

Intrusivo em rochas pré-cambrianas do terreno Apiaí-Guaxupé, o Complexo Itu (Galembeck 1991) ou Província Granítica Itu (Janasi et al. 2009) é caracterizado por um conjunto de plutons agrupados de granitóides tipo $A$, com textura rapakivi, pós-orogênicos, de idade entre 580 e 590 Ma (figura 40).

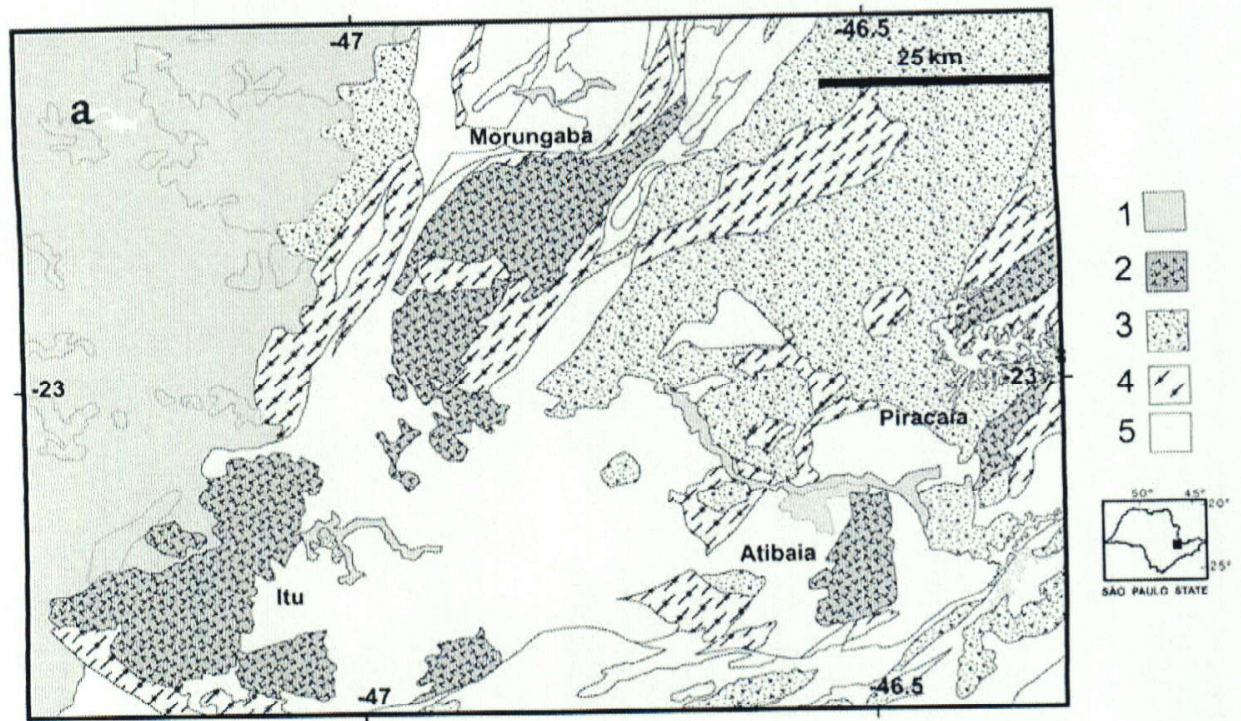

Figura 38 - Mapa geológico esquemático com a localização da Província Granítica Itu. 1) rochas sedimentares paleozoicas e rochas vulcânicas indiferenciadas (Bacia do Paraná); 2) granitóides da Província Magmática Itu (590-580 Ma). Extraído de Janasi et al. (2009), Modificado de Galembeck (1997).

Pascholati et al. (1987), em estudos objetivando caracterização radiométrica e avaliação da potencialidade metalogenética, individualizaram, com o emprego de técnicas de sensoriamento remoto, diversos corpos na "Suíte Intrusiva de Itu". Posteriormente, Galembeck (1991), com base em estudos petrográficos e de tipologia de zircão, definiu geograficamente diferentes fácies petrográficas, reconhecendo quatro principais conjuntos intrusivos, nomeados como Intrusão Salto, Indaiatuba, Itupeva e Cabreúva (figura 41). 


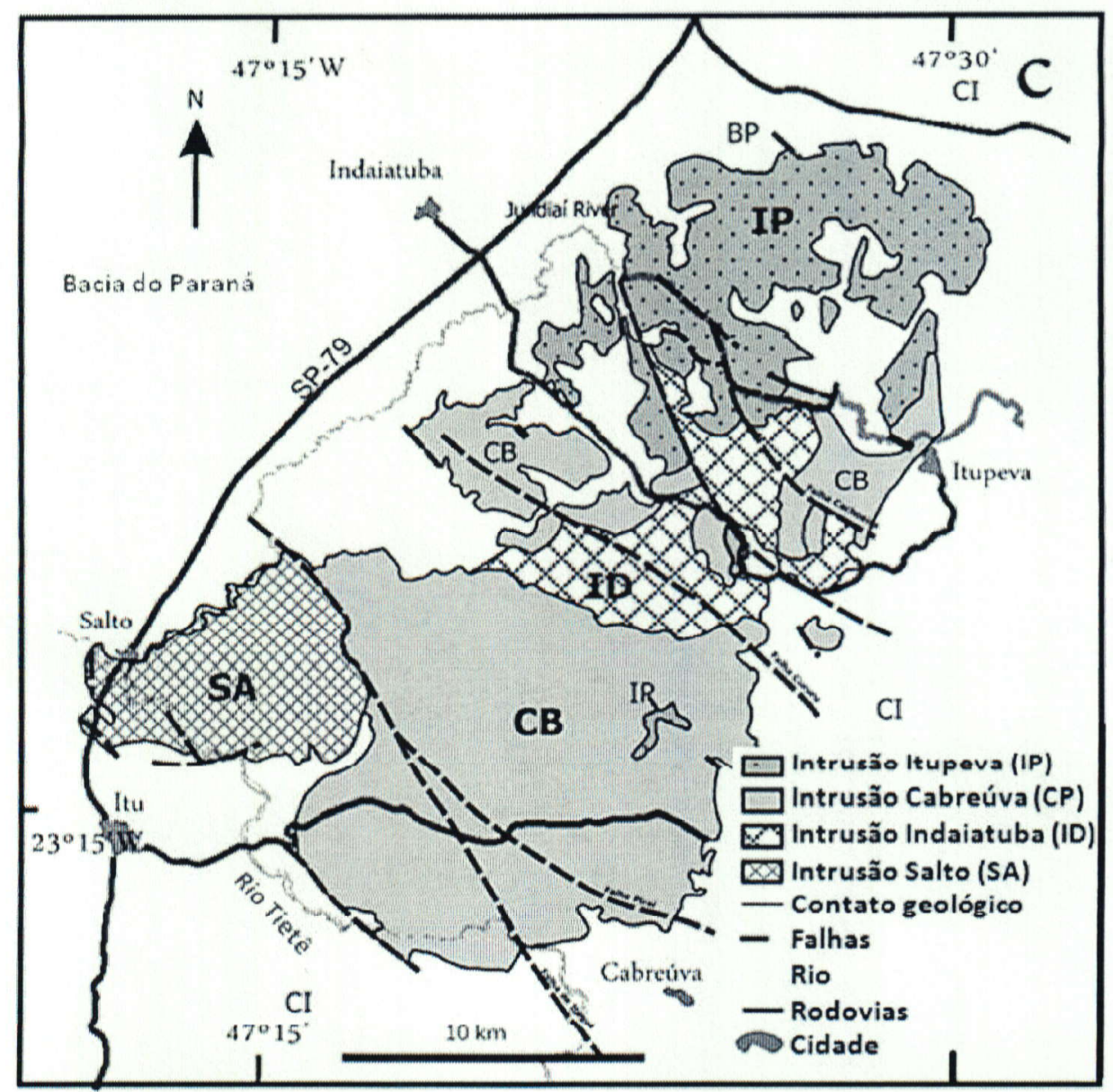

Figura 39 - Mapa esquemático do Batólito Itu. Modificado de Galembeck (1991).

A intrusão Itupeva, localizada na porção norte, é dominada por biotita monzogranitos inequigranulares. Possui um zoneamento inverso em conteúdo de máficos, aumentando em direção ao centro, provavelmente refletindo a mistura in situ com magmas básicos. Localizado na porção sul e central, a intrusão Cabreúva é o maior pluton do complexo. É dominado por biotita sienogranito de granulação grossa avermelhada e, raramente, encraves máficos microgranulares. A intrusão Salto, encontrada na porção ocidental do complexo, é constituída por granitos porfiriticos e porfiróides rapakivi. A textura rapakivi é caracteristicamente generalizada pelo pluton. Com características semelhantes, a intrusão Indaiatuba, situada no centro do complexo adjacente a intrusão Cabreúva, é formada por granitos porifiróides destacadamente grossos e com textura rapakivi. 


\subsubsection{CONTEXTO TECTÔNICO LOCAL}

Hasui et al. (1969, 1971) descreveram a influência das zonas de cisalhamento Jundiuvira e Itu sobre os corpos graníticos Sorocaba e Itu. As rochas graníticas da região de Itu foram consideradas corpos pós-tectônicos truncados por falhas, neste caso mais especificamente a denominada Falha de Itu (Hasui et al. 1969). Posteriormente,

Com o emprego de produtos de sensoriamento remoto e fotografias convencionais, Pascholati et al. 1987 caracterizaram o limite sul do complexo, observando o contato do batólito com metassedimentos do Grupo São Roque controlados pela ZCJ, além de "zonas de falhas curvadas, grosseiramente paralelas ou convergentes" à megaestrutura. Em observações de campo, os autores descreveram zonas de cisalhamento decamétricas com cataclasitos e milonitos, além de estrias de atrito determinando movimentos laterais. Também foi observado que as rochas normalmente apresentam estruturas maciças, sendo raras as evidências de foliações em mesoescala, evidenciando a natureza posterior dessas estruturas rúpteis à consolidação dos magmas.

Em trabalho recente, Janasi et al. (2010), analisaram a petrogênese dos plutons e seu significado tectônico na evolução dos terrenos. Inicialmente, observou-se que granitóides tipo-A são produtos de fusão da crosta inferior, somados a injeção de fluídos e/ou derivações de frações de magmas básicos Esses magmas são resultantes da ascensão da astenosfera, possivelmente, ao longo de zonas de cisalhamento em niveis rasos. Essa dinâmica é reflexo dos processos orogênicos no Sistema Orogênico Mantiqueira, onde os movimentos iniciais de convergência foram substituídos por uma transcorrência destral, deslocando terrenos de diferentes naturezas, gerando fraqueza crustal (slabbreakoff model) e consequente ascensão astenosférica.

Nesta dissertação, seguindo a proposta da CPRM (2006), a Zona de Cisalhamento Itu, conforme Hasui et al. (1969), é admitida como continuidade da ZCJ na região. 


\subsubsection{ANÁLISE CINEMÁtICA E PALEOTENSÕES NO GRANITO ITU ASSOCIADAS À ZONA DE CISALHAMENTO JUNDIUVIRA}

Os dados utilizados para Província Granítica Itu foram obtidos no banco de dados do Laboratório de Neotectônica do GSA, IG-USP, e foram obtidos pelo orientador da presente dissertação em 1994.

As estruturas descritas são estritamente rúpteis, caracterizando um evento posterior à colocação das rochas e resfriamento do magma.

As falhas rúpteis são conjugadas e apresentam direções predominantes NW e NE, com mergulhos subverticais. As estrias de atrito são muito evidentes e as superfícies apresentam rugosidades assimétricas representadas por pequenas fraturas $R$, que indicam movimentações destrais para as falhas NW e sinistrais para as NE

A figura 42 indica o campo de esforços com base nas falhas, com movimentação lateral resultante dos esforços compressivos máximo $\left(\sigma_{1}\right) \mathrm{NNE}-$ SSW e mínimo $\left(\sigma_{3}\right)$ WNW-ESSE.

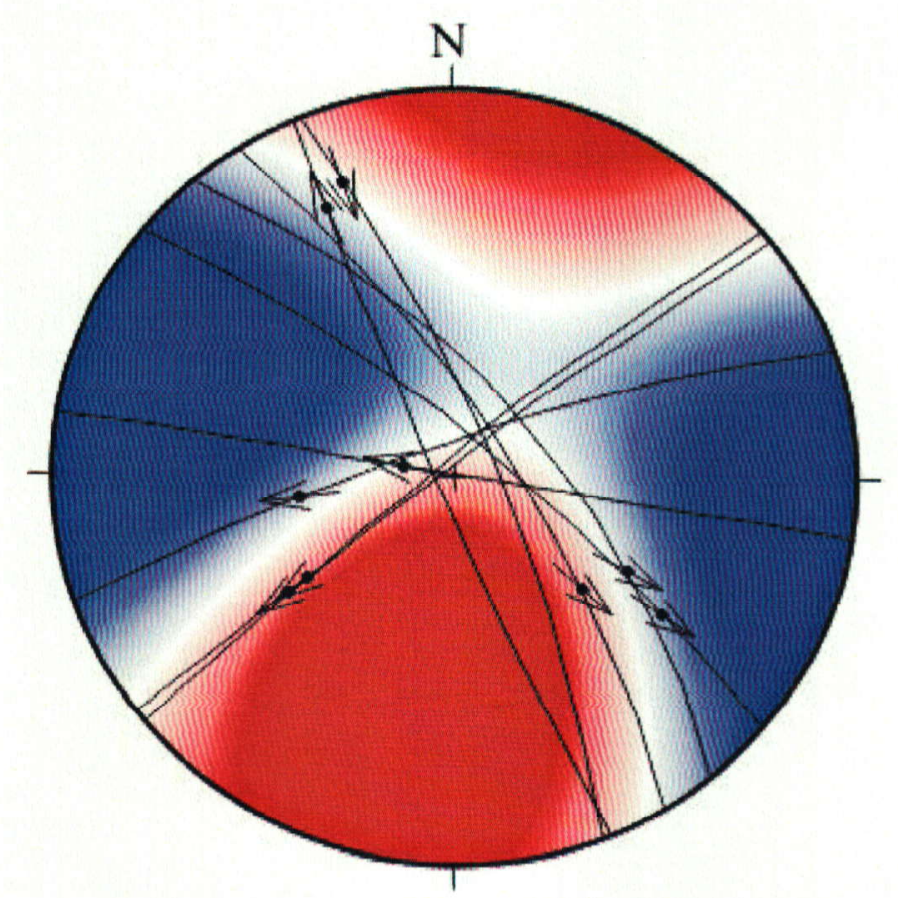

Figura 40 - Determinação do campo de esforços para falhas transcorrentes destrais e sinistrais, resultantes dos esforços compressivos máximo o1 NNE-SSW e mínimo $\sigma 3$ WNW-ESE. 


\subsection{PLANALTO DE CAMPOS DO JORDÃO}

O Planalto de Campos do Jordão é um platô compartimentado em blocos, alçado às cotas altimétricas superiores a $2000 \mathrm{~m}$ de altitude, que constitui uma superfície cimeira no sudeste do Brasil (v.g. Modenesi Gauttieri et al. 2001) . O planalto localiza-se na porção sudoeste do principal bloco da Serra da Mantiqueira, e apresenta as principais feições morfológicas indicativas de tectonismo recente, onde a paisagem resulta da interação de controles climático e neotectônico, responsáveis pela compartimentarão do relevo (Hiruma, 1999).

O Planalto de Campos do Jordão está regionalmente inserido no segmento central localizado no sistema orogênico da Província Mantiqueira (Almeida et al. 1981). As unidades geológicas que compõem a região do Planalto de Campos do Jordão limitam-se, basicamente, em um embasamento pré-cambriano e coberturas quaternárias colúvio-aluviais e colúvio-eluviais.

Localmente são descritos litotipos como para e ortognaisses, rochas calcissilicáticas, metamargas, quatzitos feldspáticos e anfibolitos referentes a esses terrenos, progressivamente milonitizados conforme sua proximidade com a ZCJ. Além desses são encontrados metassedimentos referentes à Bacia do Pico do Itapeva.

\subsubsection{BACIA EDIACARANA DO PICO DO ITAPEVA}

\subsubsection{INTRODUÇÃO}

As rochas metassedimentares da Bacia do Pico do Itapeva encontramse localizados a sudeste de Campos do Jordão, no Estado de São Paulo. Estes depósitos. Estes depósitos foram relacionados tentativamente ao Grupo Açungui (Hasui et al. 1978). Posteriormente, Cavalcante et al. (1979), notando as diferenças com litotipos adjacentes e a natureza epimetamórfica dos depósitos, nomearam informalmente essas rochas como Formação Pico do Itapeva, considerando-as como depósitos "anômalos na região" e correlacionáveis às formações Pouso Alegre e Eleutério. 
O estudo estratigráfico da bacia teve início com o trabalho de Juliani et al. (1990). Posteriormente, Teixeira (2000) reconheceu na bacia quatro associações de fácies (figura 43). Na base foram descritos ritmitos com estruturas heterolíticas laminadas de arenitos finos a médios com siltitos argilosos violáceos, intercalados por estratos tabulares de conglomerados polimíticos clasto-suportados com seixos de rochas granitóides e de quartzitos. A deposição dessa fácies refletiria um ambiente estuarino ou de planície de marés com águas rasas relacionados com calmaria tectônica. Acima, em contato erosivo, são encontrados arenitos finos a médios com estratificações cruzadas de baixo ângulo, localmente com marcas de ondas de tempestade (hummocky). Essa segunda fácies aparentemente seria produto de regressão marinha e, possivelmente, oscilações climáticas ligadas às ondas de tempestades. Sobrejacente a esta última, ocorrem intercalações de conglomerados finos polimíticos, maciços ou estratificados e arenitos mal selecionados subordinados, em estratos com aumento granulométrico e espessamento rumo ao topo. No topo da sucessão, em contato gradual com a unidade sotoposta, foram descritos conglomerados polimíticos grossos clastosustentados, com intercalações de arenitos mal selecionados com estratificação plano-paralela (tapetes de tração), evidenciando o máximo regressivo na bacia, e interpretados como depósitos de fan-deltas que evoluíram a leques aluviais continentais.

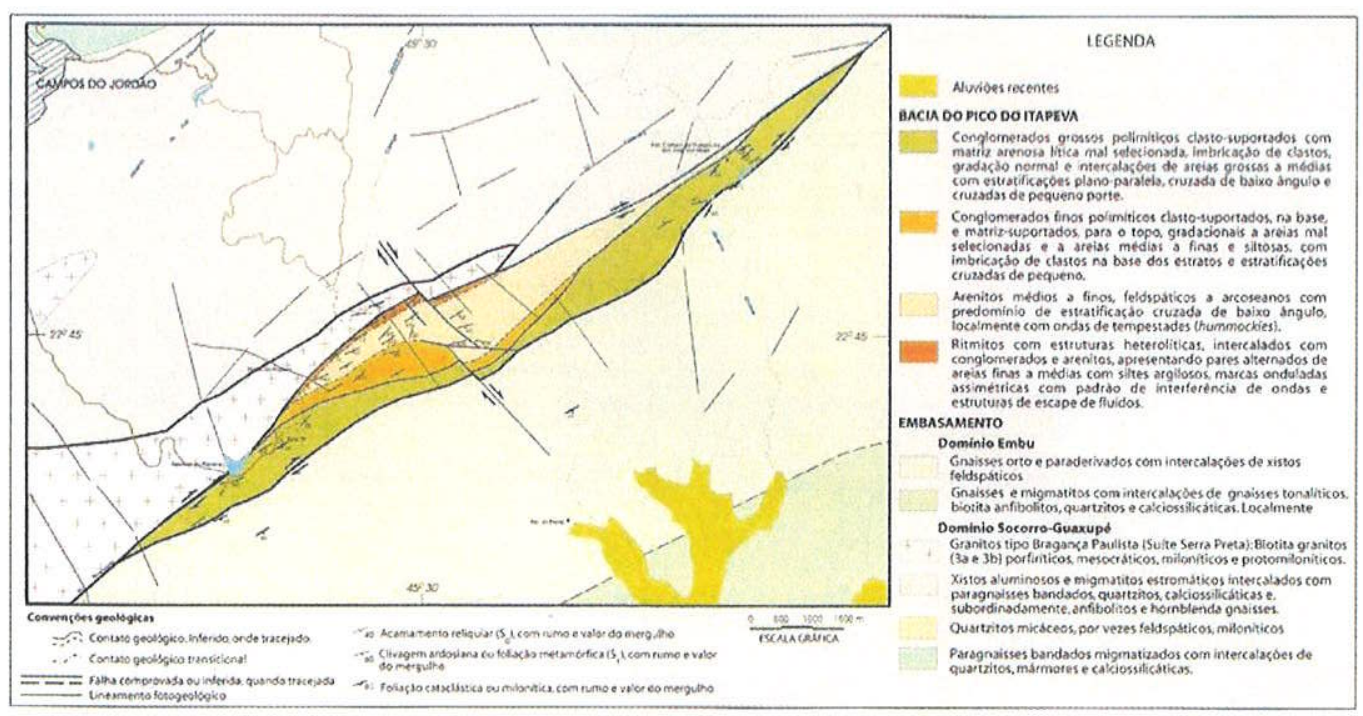

Figura 41 - Mapa de distribuição de litofácies na Bacia do Pico do Itapeva. Extraído de Teixeira et al. (2004). 
Os depósitos da Formação Pico de Itapeva tem sido referidos ao Ediacarano-Cambriano, como base em seu conteúdo fossilífero (Teixeira et al. 2004), ou correlações regionais (Almeida et al. 2010).

\subsubsection{CONTEXTO TECTÔNICO LOCAL}

A Bacia do Pico do Itapeva teve sua evolução compreendida, provavelmente, entre o Ediacarano e o Ordoviciano Inferior a Médio, aproximadamente entre 600 e $470 \mathrm{Ma}$ (Teixeira et al. 2004).Os metassedimentos da bacia, que estão confinados em uma estrutura remanescente de formato lenticular, com orientação paralela as estruturas do embasamento (NE-SW), são limitadas pela zona de cisalhamento ou ramificações de Jundiuvira (Hasui et al. 1978), estabelecendo, portanto, contato tectônico com as rochas encaixantes.

As relações entre a ZCJ e os depósitos da Bacia do Pico do Itapeva transcendem os limites geométricos, pois caracterizam a tectônica formadora e deformadora desses metassedimentos.

Juliani et al. (1990) descreveram o contato tectônico dos pacotes epimetamórficos com as rochas encaixantes da região. Posteriormente, Riccomini (1993), propôs origem relacionada à movimentação lateral sinistral da zona de cisalhamento, resultando no local em uma bacia tipo pull-apart. Essa gênese foi discutida por Teixeira (2000), que ele propôs uma origem vinculada ao resfriamento pós-brasiliano dos blocos recém-agregados e à contração térmica dos terrenos relacionados a movimentações laterais obliquas, formando blocos subsidentes em contexto transcorrente (strike-slip basins) (Teixeira et al. 2004). Almeida et al. (2010) relacionaram a evolução tectônica das bacias de transição do leste da Plataforma Sul-Americana com um sistema de rifts, determinando um campo de esforços distensivo pósbrasiliano.

Estruturalmente, os depósitos da Bacia do Pico do Itapeva, apresentam um acamamento reliquiliar $\left(S_{0}\right)$ bem marcado, com direção NE-SW e rumo médio de mergulho para SE, em torno de $60^{\circ}$ (figura $44 \mathrm{~A}$ ). Cavalcante et al. (1979) perceberam uma "marcante foliação cataclástica, com mergulhos para 
sul, bem marcante no nível conglomerático". Essa deformação foi caracterizada por Juliani et al. (1990) que relacionaram as estruturas com um sinclinal e, possivelmente, mais de um evento pouco evidente.

A inversão da bacia foi relacionada a esforços compressivos oblíquos, com transporte para noroeste, resultantes da movimentação destral da ZCJ por Riccomini (1993), corroborando com a formação de uma estrutura sinclinal isoclinal proposta por Juliani et al. (1990). Essa observação não pode ser confirmada por Teixeira (2000), que descreveu clivagens ardosianas $\left(\mathrm{S}_{1}\right)$ que cortam o acamamento e apresentam direção sub-paralela a este, porém com mergulhos mais acentuados, entre $75^{\circ}$ e $80^{\circ}$ (figura $44 \mathrm{~B}$ ).

Esses eventos deformadores são associados por Teixeira (2000) ao início do Cambriano, com idade máxima em torno de $530 \mathrm{Ma}$.
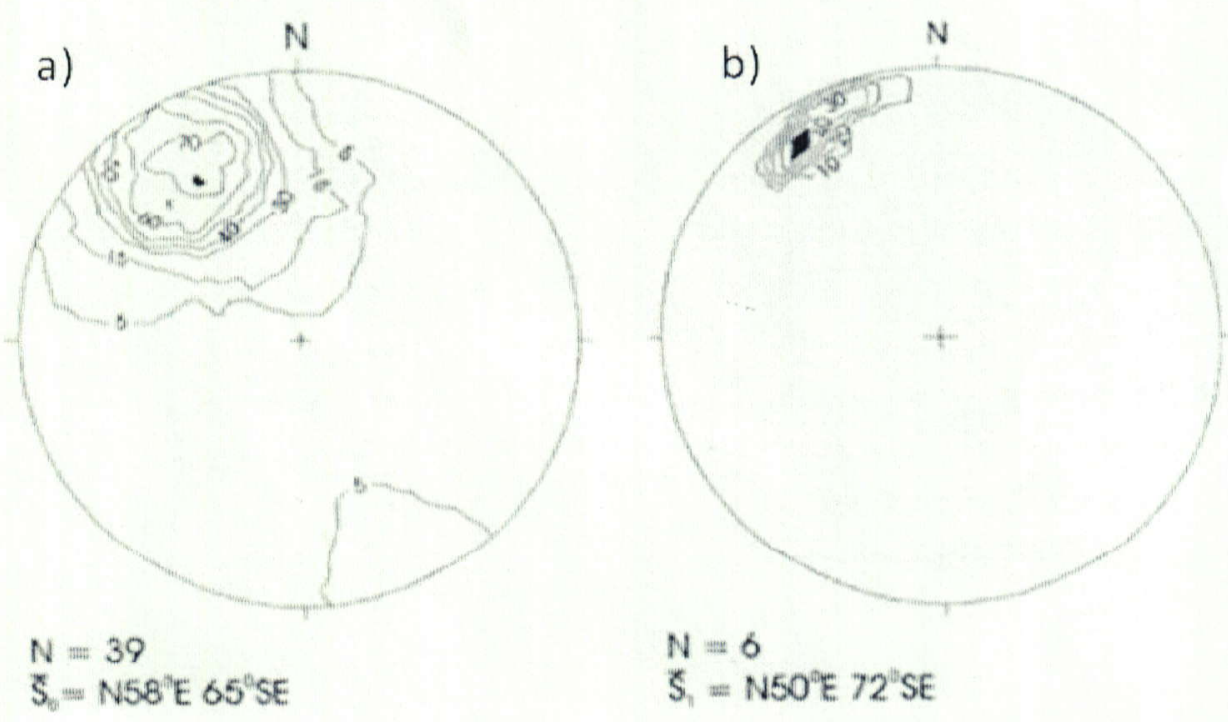

Figura 42 - Diagrama de densidade de pólos. a) acamamento reliquiar (SO) e atitude média das medidas; b) foliação metamórfica (S1) e atitude média das medidas. Extraído de Teixeira 2000.

\subsubsection{ANÁLISE CINEMÁTICA E PALEOTENSÕES NA BACIA DO PICO DE ITAPEVA ASSOCIADAS À ZONA DE CISALHAMENTO JUNDIUVIRA}

Com base em medidas de acamamento reliquiar $\left(S_{0}\right)$ e planos de cisalhamento $\left(\mathrm{S}_{\mathrm{c}}\right)$ relacionados à deformação posterior, obtidas no banco de 
dados do laboratório de Neotectônica da Universidade de São Paulo, foram caracterizadas ambas as estruturas e esforços relacionados.

Em toda a bacia o acamamento reliquiar é bem evidente e caracterizado em toda a sucessão estratigráfica A figura 45 apresenta a distribuição e densidade de pólos referentes à $\mathrm{S}_{0}$ extraídas em todas as litofácies, as quais mostram orientação geral NE-SW e mergulhos médios para SE.

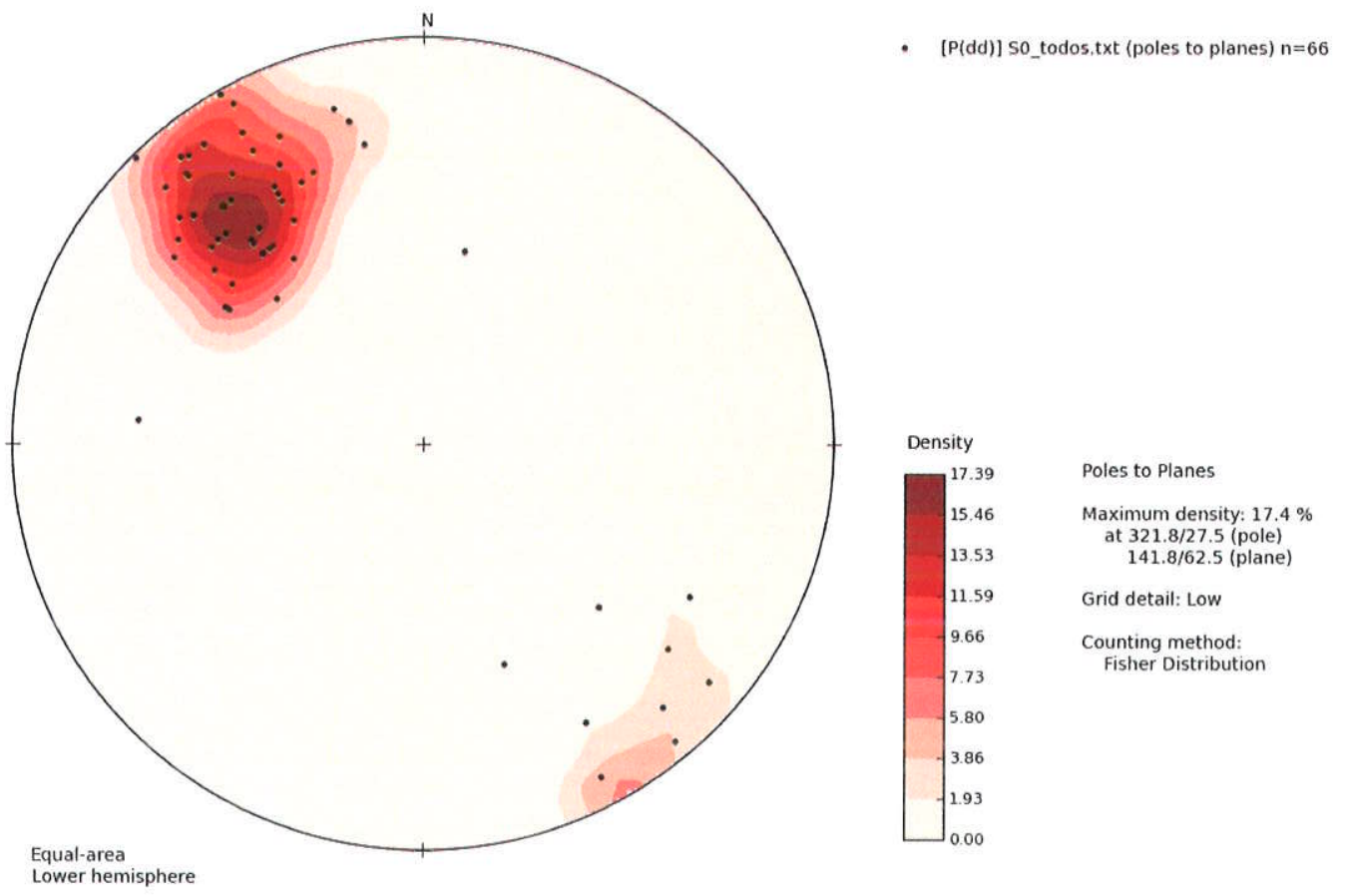

Figura 43 - Diagrama com distribuição dos pólos do acamamento reliquiar So, segundo a direção NE-SW, com mergulhos para SE, obtidos na Bacia do Pico do Itapeva.

A deformação dúctil na bacia, descrita como inversão e encurtamento, está relacionada a estruturas bem evidentes, apresentadas como estiramento dos clastos, clivagem ardosiana e foliação cataclástica (Juliani et al. 1990, Riccomini 1993, Teixeira 2000).

A figura 46 apresenta a distribuição e densidade dos pólos de planos $S_{c}$, caracteristicamente subparalela ao acamamento $S_{0}$, com mergulhos para SE ligeiramente maiores, além das lineações de cisalhamento, com mergulhos baixos e sentido de movimentação geral de E-ESE para W-WNW. Cabe 
ressaltar que foram obtidos poucos dados pareados, optando-se por não apresentá-los contidos em círculos máximos.

Os resultados obtidos para a deformação sugerem esforços compressivos, os quais, em função da orientação da ZCJ, indicam movimentação oblíqua ou transpressiva, destral, como anteriormente sugerido por outros autores.

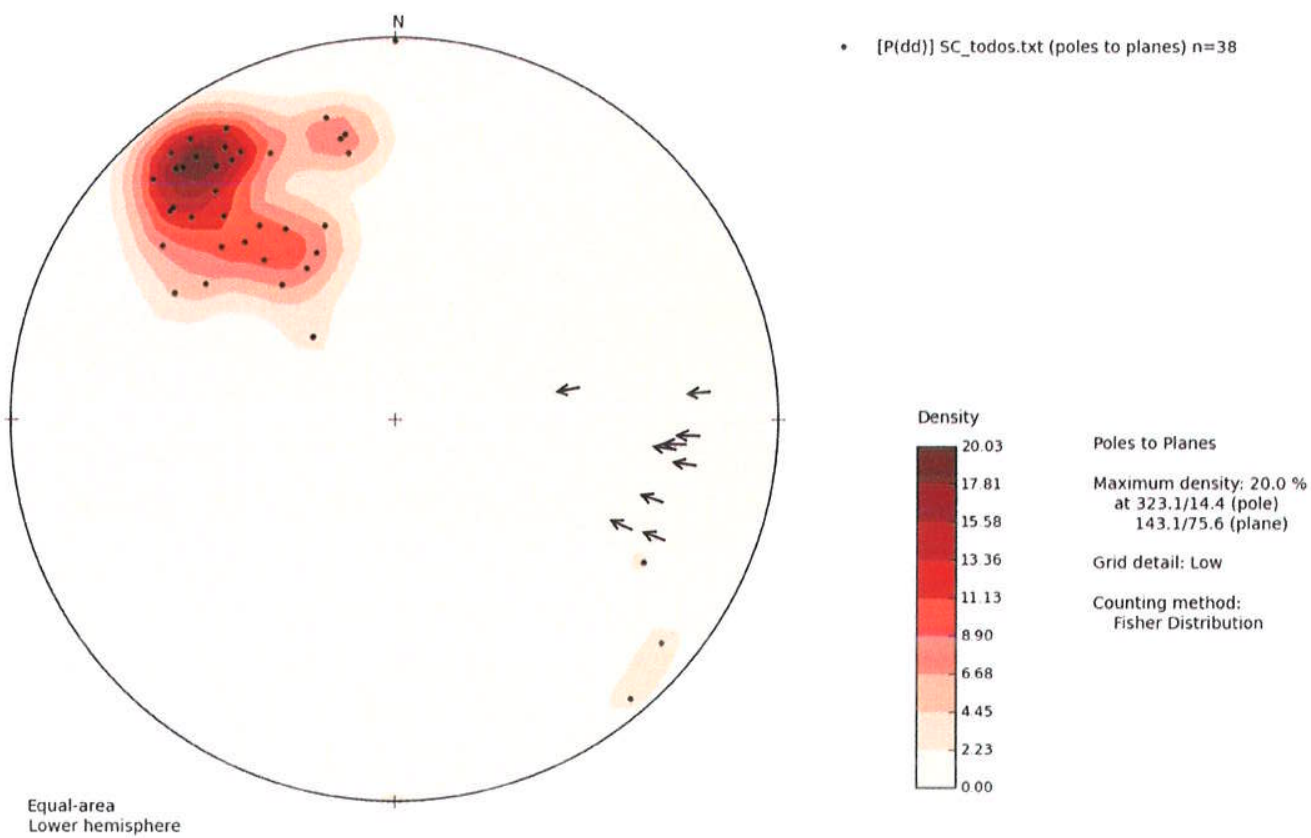

Figura 44 - Diagrama com distribuição dos pólos das foliações (SC) e lineações (Lc) de cisalhamento obtidos na Bacia do Pico do Itapeva, demonstrando esforços compressivos de direção NW-SE.

\subsubsection{DEPÓSITOS QUATERNÁRIOS DO PLANALTO DE CAMPOS DO JORDÃO}

A sedimentação quaternária, conforme Modenesi (1984, 1988), parece estar ligada a evolução de três anfiteatros (I, II e II), relacionadas à ação de pequenos movimentos de massa ou à concentração do escoamento superficial, amplificados por escorregamentos mais profundos (slump-slides) e subsequentes escorregamentos superficiais ou corridas de sedimentos (mudflow e debris-flow). 
Segundo a autora, há registros da sucessão de episódios holocênicos de estabilidade morfodinâmica. Colúvios representariam três fases de atividades erosivas, enquanto paleossolos enterrados indicariam intervalos de tempo de menor atividade denudacional com pedogênese. Conjuntamente, são observados sedimentos turfosos cujas análises palinológicas sugerem variações climáticas no Holoceno.

Feição marcante observada e de grande continuidade horizontal são as stone lines. Hiruma (1999) descreve duas gerações destas intercaladas com colúvios, uma inferior, mais importante, possivelmente relacionada à fase de pavimentação detrítica no final do Pleistoceno e outra superior, associada a processos de clima seco em fase intramholocênica.

\subsubsection{EVOLUÇÃO TECTÓNICA LOCAL}

O Planalto de Campos do Jordão apresenta uma série de evidências de deformações tectônicas cenozóicas (Hiruma 1999, Modenese-Gauttieri et al. 2001, Hiruma et al. 2001).

A sobrelevação final dessa feição geomorfológica ocorreu durante o final do quaternário, paralela a inserção do Rift Continental do Sudeste do Brasil (Riccomini 1989).

A configuração atual do relevo no sudeste do Brasil é representado pelas feições elevadas como as serras do Mar e da Mantiqueira e as rebaixadas, com as bacias integrantes do rift. O modelo proposto segundo Riccomini (1989) compreende quatro fases tectônicas, no qual, no Planalto de Campos do Jordão, as duas últimas, transcorrência destral neopleistocênica e distensão holocênica, estão visivelmente marcadas pelas relações de corte entre estruturas rúpteis e depósitos sedimentares.

Hiruma (1999) analisando a sedimentação quaternária em conjunto com dados estruturais, reconheceu esses dois últimos eventos somados a um posterior mais recente. Segundo o autor, a evolução dos campos de esforços neotectônicos (figura 47), pode ser assim resumida: 
- transcorrência destral pleistocênica, com binário orientado E-W e compressão NW-SE; nessa fase ocorrem falhas transcorrentes de direções NNW-SSE, ENE-WSW e WNW-ESSE que cortam stone lines;

- distensão E-W a NW-SE, holocênica; esse regime é evidenciado por falhas normais de direção NE-SW afetando horizontes húmicos superficiais, datados em $9.250 \pm 170 \mathrm{AP}$ e $8.630 \pm 80 \mathrm{AP}$;

- compressão E-W a NW-SE, durante o correspondente Holoceno tardio;. possivelmente esse campo relaciona-se aos esforços atuantes na placa até o presente, marcado no planalto por falhas inversas e juntas neotectônicas em depósitos coluviais datados de $3.410 \pm 80 \mathrm{AP}$.

Hiruma $(1999,2001)$ relacionam os dois primeiros eventos à reativação da ZCJ, inicialmente como uma transcorrência destral e posteriormente por movimentação normal.

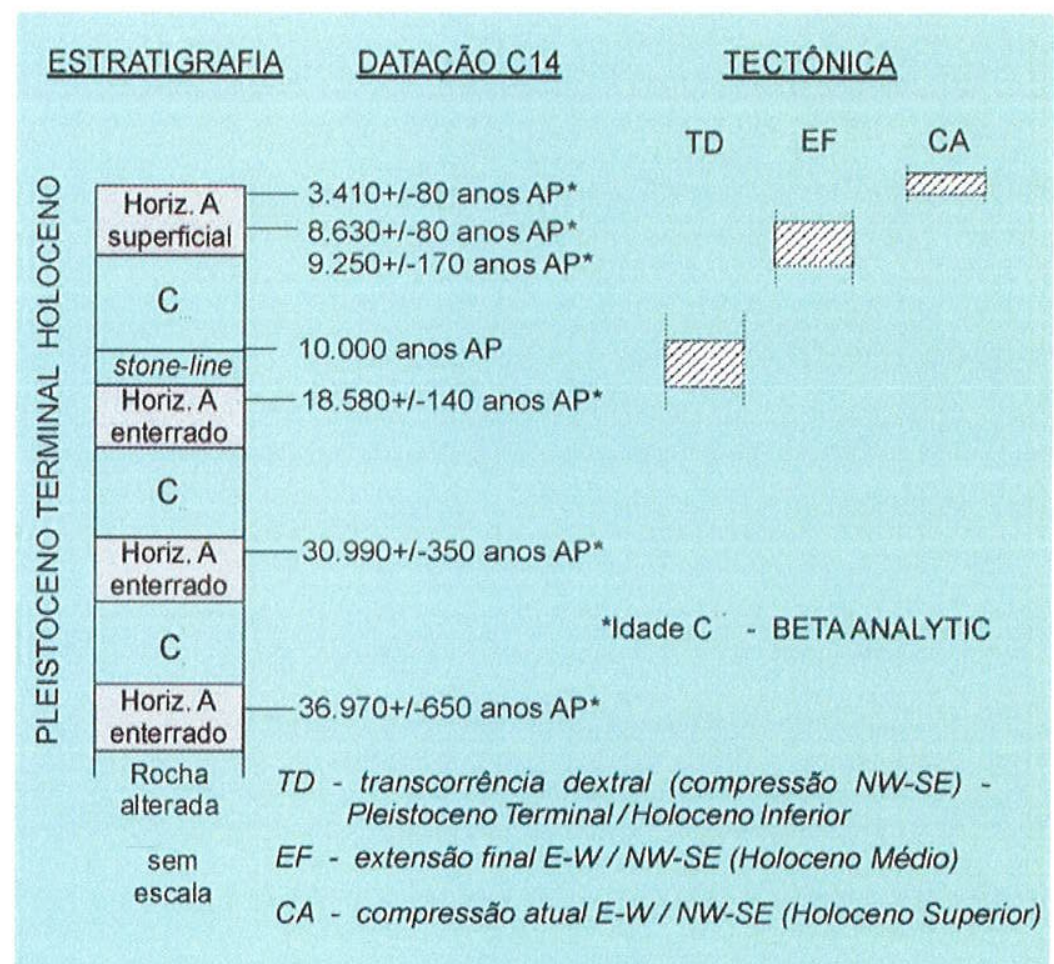

Figura 45 - Quadro de relação entre a sedimentação quaternária e a neotectônica no Planalto de Campos do Jordão. Extraído de Hiruma et al. (2001). 


\subsubsection{ANÁLISE CINEMÁtICA E PALEOTENSÕES EM DEPÓSITOS QUATERNÁRIOS DISPOSTOS SOBRE A ZONA DE CISALHAMENTO JUNDIUVIRA}

A análise de palecampos de tensões no Planalto de Campos do Jordão foi efetuada mediante a obtenção de dados pareados de falhas e respectivas estrias em afloramento ao longo de estrada vicinal próxima ao mirante do Pico do Itapeva, Município de Pindamonhangaba, e a reavaliação de dados extraídos de Hiruma (1999) para familias de juntas conjugadas que afetam colúvios e horizontes húmicos ao longo da ZCJ.

Em exposição localizada nas proximidades do limite tectônico da Bacia do Pico do itapeva com o embasamento pré-cambriano foram observadas falhas embutindo depósitos coluviais e paleossolos. A rocha do embasamento é um milonito-gnaisse da ZCJ. No interior da cunha delimitada por falhas (figura 48) ocorrem colúvios areno-argilosos, maciços, de coloração castanhoamarelada, e neles encontram-se intercalados quatro horizontes de paleossolos areno-argilosos com matéria orgânica e coloração cinza escura, de espessuras centimétricas a decimétricas. Fora da cunha, as rochas do embasamento são cobertas por depósito coluvial areno-argiloso amarelado a alaranjado, com stone line composta por clastos centimétricos a decimétricos de quartzito e concreções aluminosas na base.

Idade $14 \mathrm{C}$ convencional de $21.660 \pm 270$ anos A.P. foi obtida para amostra da base do paleossolo superior (P4) (Hiruma et al. inédito). Posteriormente, foi obtida idade 14C em acelerador (AMS) de $23.820 \pm 120$ anos A.P. para o horizonte de paleossolo (P3) situado imediatamente abaixo do anterior (Riccomini et al. inédito).

As falhas que embutem a cunha de colúvios e paleossolos apresentam direções médias NNE-SSW, são subverticais para NW e apresentam deslocamentos com componentes transcorrentes sinistrais (figuraXXX), determinados pela observação de estrias como marcas de objetos. Estas falhas resultam de um paleocampo de esforços com $\sigma_{1}$ NW-SE e $\sigma_{3}$ NE-SW (figura 49). 


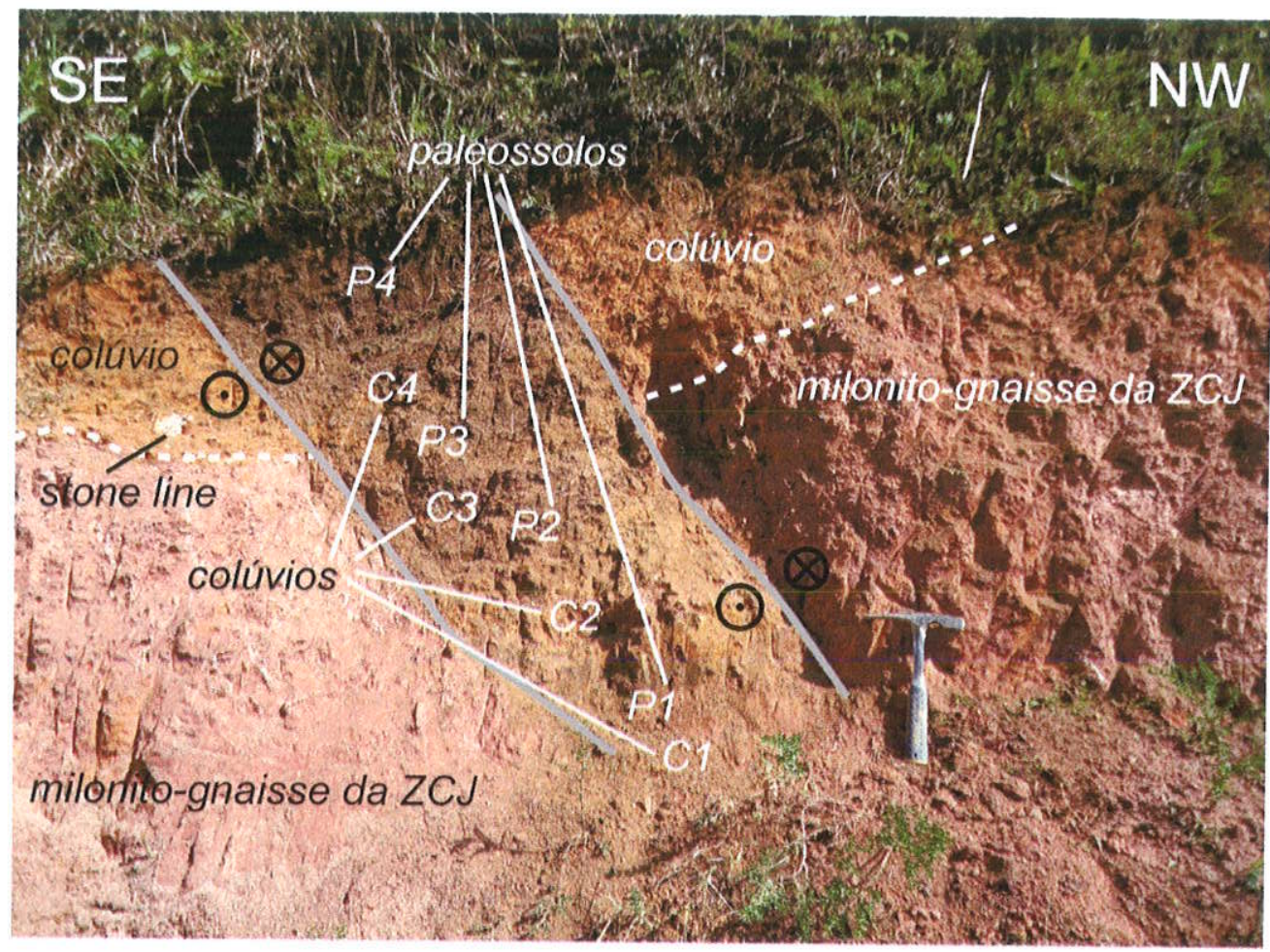

Figura 46 - Falhas de componente transcorrente sinistral de orientação NNE-SSW embutindo tectonicamente colúvios (C1 a C4) e horizontes de paleossolos (P1 a P4) pleistocênicos, em gnaisses milonitizados da ZCJ.

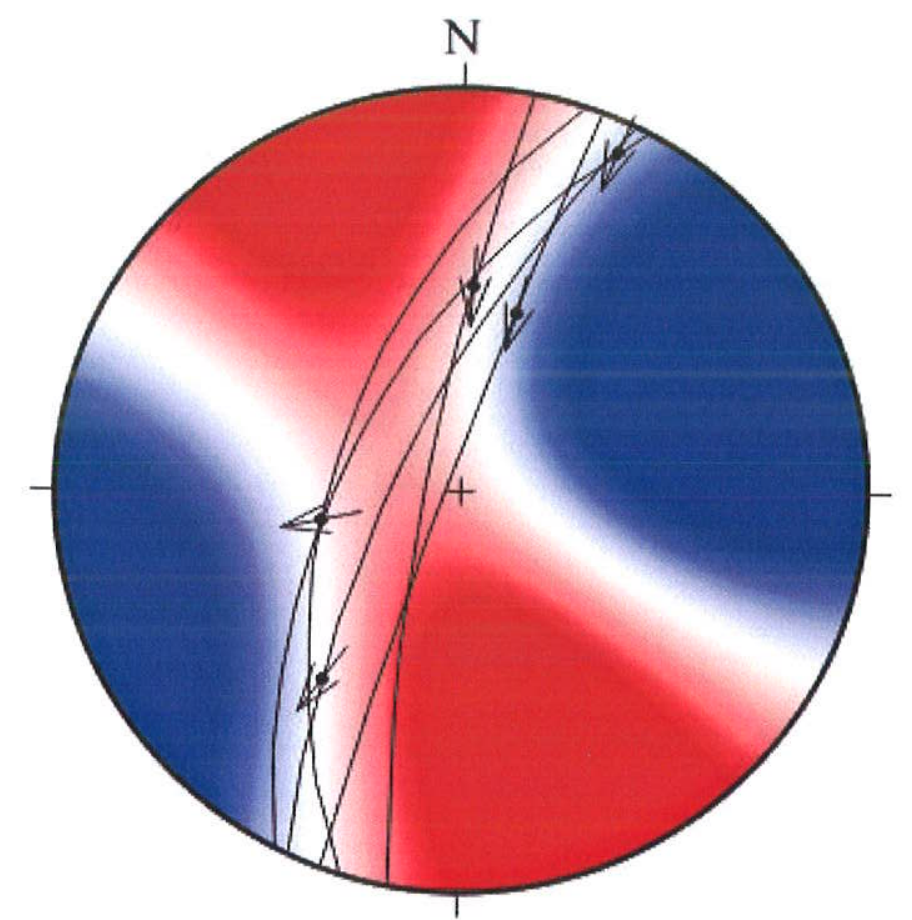

Figura 47 - Determinação do campo de esforços para falhas de direção NNE e componentes sinistrais que afetam os depósitos coluviais e paleossolos pleistocenos, resultantes de esforços com o1 NW-SE e o3 NE-SW. 
Para a região do Planalto de Campos do Jordão foram selecionados também dados estruturais de juntas neotectônicas de exposições situadas sobre o traçado da ZCJ, extraídos do trabalho de Hiruma (1999).

Segundo o autor, essas estruturas correspondem a juntas de cisalhamento subverticais que afetam stone lines, depósitos de colúvios e turfas datados do holoceno, com idade $14 \mathrm{C}$ de $3.410 \pm 80$ anos A.P. O campo de esforços determinado pelo autor corresponde a um regime compressivo de direção $E-W$, compatível as direções de esforços obtidas a partir de dados geofísicos.

Apesar da grande dispersão dos dados, grande parte das atitudes reflete direções subparalelas à ZCJ.

Os dados foram plotados em mapa hipsométrico (figura 50) com o objetivo de analisar correlações com a escarpa da Serra da Mantiqueira e o alívio lateral causado pelo desnivel altimétrico adjacente, o que poderia ter alterado as relações entre o esforço intermediário e mínimo. Entretanto, com o número de dados disponivel não foi possivel determinar essa influência. Verificou-se, por outro lado, que a distribuição de juntas em depósitos holocênicos dispostos sobre a ZCJ reflete direções de esforços com SHmáx paralelos ou ortogonais a ZCJ. 


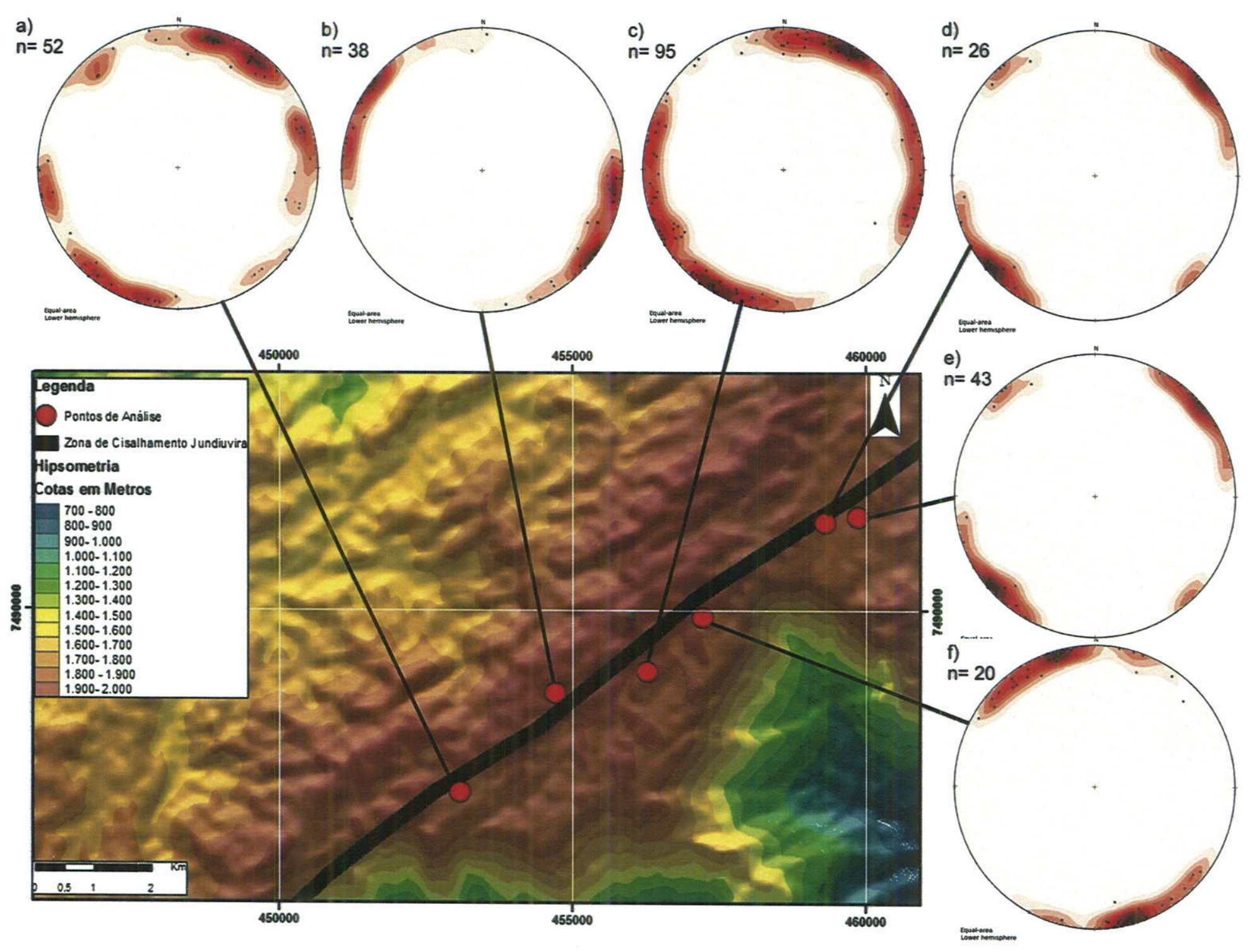

Figura 50 - Mapa hipsométrico na região do Planalto de Campos do Jordão com diagramas polares de juntas de cisalhamento ao longo da ZCJ. 


\subsection{MACIÇO ALCALINO DE PASSA QUATRO}

\subsubsection{INTRODUÇÃO}

O Maciço Alcalino de Passa Quatro, localizado na Serra da Mantiqueira, entre os estados de São Paulo, Minas Gerais e Rio de Janeiro, é um batólito de idade mesozoico-cenozoica intrusivo em rochas pré-cambrianas da Província Mantiqueira.

O maciço é constituído por rochas félsicas, fortemente insaturadas, representadas por nefelina sienitos, sodalita nefelina sienitos laminados, nefelina microssienitos e subordinadamente afanítica, ocorrendo como brechas magmáticas alcalinas, fonolitos, traquitos e lamprófiros (Ribeiro Filho 1964, Chiessi 2004). Um mapa geológico de semi-detalhe (figura 51) foi elaborado por Chiessi (2004), com a representação da distribuição dos principais litotipos, incluindo diques de diferentes composiçôes, objeto de análise nesta dissertação. 


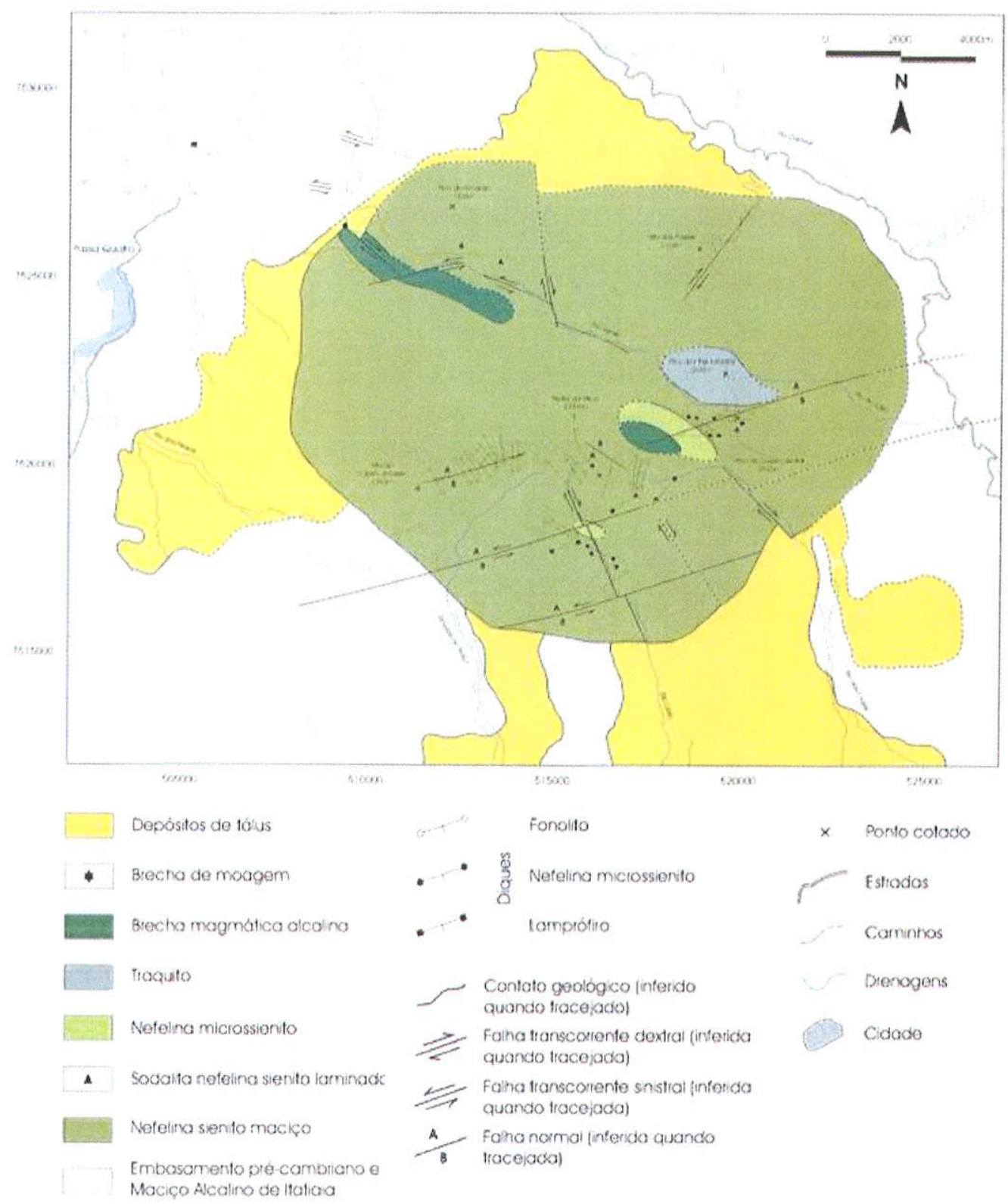

Figura 48- Esboço geológico do Maciço Alcalino de Passa Quatro. Extraído de Chiessi (2004).

\subsubsection{EVOLUÇÃO TECTÔNICA LOCAL}

O Maciço Alcalino de Passa Quatro é um complexo alcalino de geometria elíptica, com idade aproximada de $70 \mathrm{Ma}$ (Neocretáceo) e que vem sendo tradicionalmente inserido no contexto tectônico do Alinhamento Magmático de Cabo Frio (Almeida 1991, Riccomini et al. 2005). 
Agrupamentos de maciços alcalinos já haviam chamado a atenção de diversos autores, muitas vezes tentando relacionar sua origem com eventos tectônicos na Placa Sul-americana. Com base nas descrições iniciais e o agrupamento dos corpos rochosos descritos por Almeida (1976), Sadowski \& Dias Neto (1981) definiram o "Lineamento de Sismo-Tectônico de Cabo Frio", de orientação próxima a E-W. Com base nas idades disponiveis para essas rochas, Sadowski \& Dias Neto (1981) estimaram uma possivel relação da taxa de abertura do Atlântico Sul com a rotação da Placa Sul-americana. Segundo estes últimos autores, a porção oriental dessa feição teria relação com estruturas crustais, como o Lineamento do Rio de Janeiro (Asmus 1978), além de implicações sísmicas (Assunção 1980), com epicentros distribuídos ao de sua extensão, embora consideráveis erros de precisão na localização fossem reconhecidos.

Acrescentando novas observações e discussões quanto à natureza geológica da feição, Almeida (1981) entendeu que a denominação "alinhamento magmático" expressaria melhor sua natureza intrusiva, o que suprimiria, segundo ele, a característica sismo-tectônica antes utilizada. Nesse mesmo trabalho, o autor incluiu no alinhamento o banco submarino de Almirante Saldanha, a leste, e o corpo alcalino de Jaboticabal, localizado no interior da Bacia do Paraná, confirmando a variação não linear das idades das rochas alcalinas, fato reafirmado em estudos efetuados na última década (e.g. Riccomini et al. 2005) (figura 52).

Segundo Almeida (1981), Ferrari (2001) e Riccomini et al. (2005), o Alinhamento Magmático de Cabo Frio indicaria a existência de falhas subcrustais ao longo das quais ocorreu a fusão parcial mantélica que gerou os magmas alcalinos. A colocação desses magmas foi controlada por deslocamentos controlados por estruturas regionais pré-cambrianas, bem como pelo campo de esforços vigentes na época. Ferrari (2001) propôs a ação de um binário sinistral de orientação WNW-ESSE como mecanismo gerador de espaço para a intrusão de maciços e diques alcalinos prévios (Maciço Mendanha) a contemporâneos (Plug de Itaboraí) ao início da formação do Gráben da Guanabara e controlados por distensão NW-SE, atuante entre o Campaniano e Eoceno Inferior (80-50 Ma). Riccomini et al. 
(2005) consideraram o Alinhamento Magmático de Cabo Frio como uma província alcalina e reconheceram neste dois pulsos de atividade magmática, um durante o Neocretáceo e outro no Eoceno, ambos relacionados a um cisalhamento sinistral ao longo da feição.

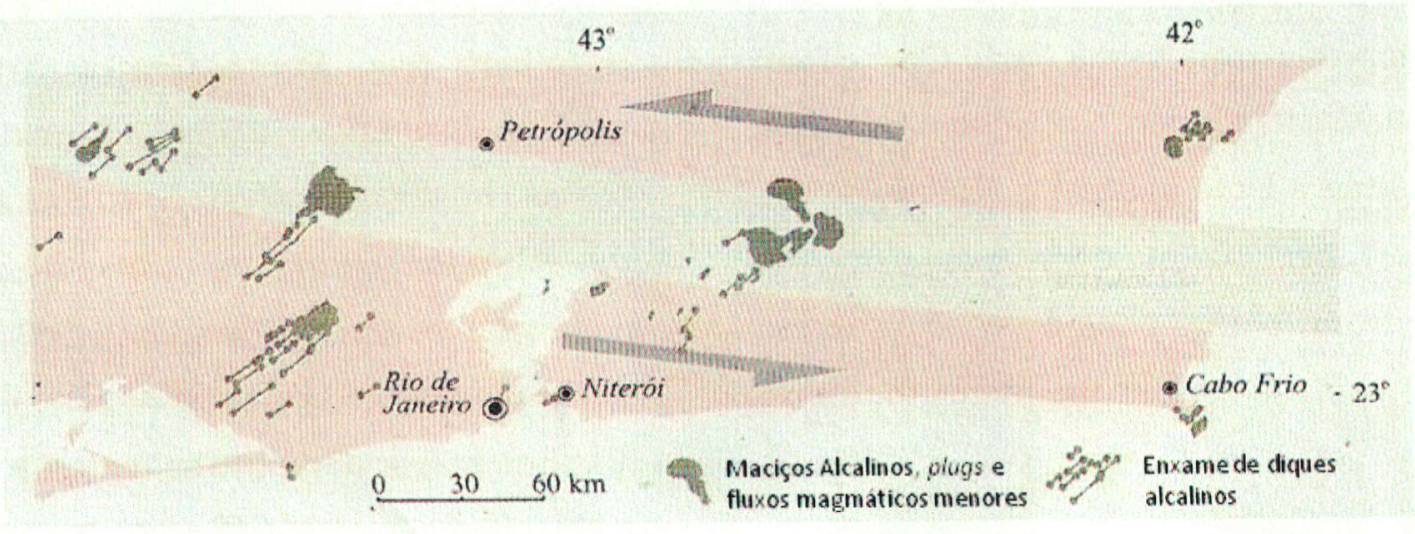

Figura 49 - Segmento oriental do Alinhamento Magmático de Cabo Frio. Distribuição de corpos alcalinos mesozoico-cenozoicos controlados por compressão NE-SW na porção centro-leste do estado do Rio de Janeiro e a indicação do binário transcorrente sinistral WNW-ESE. Extraído de Riccomini et al. (2005).

A partir de mapeamento geológico e levantamentos estruturais, Chiessi (2004) reconheceu quatro gerações de estruturas que foram associadas à evolução dos paleocampos de esforços. A primeira fase, ocorrida entre o Cretáceo Superior e o Paleoceno, corresponderia à implantação do maciço, que apresenta forma elíptica com o maior eixo orientado próximo a $\mathrm{E}-\mathrm{W}$, direção essa considerada pelo autor como próxima ao binário transcorrente sinistral indicado para a mega estrutura do Alinhamento Magmático de Cabo Frio. Esse paleocampo foi determinado pela orientação de fraturas mais antigas, bem como a atitude de diques de rochas alcalinas félsicas. Esses diques apresentam certa dispersão em relação à paleotensão proposta, o que, segundo o autor, poderia ser explicado por intrusões próximas à superfície, magnitude semelhante entre os principais tensores, magnitude semelhante entre a pressão do magma e os principais tensores, além da possível relação entre os corpos, de orientações NNW-SSE e WNW-ESE, e fraturas secundárias $\mathrm{P}$ e $\mathrm{X}$ do binário proposto. $\mathrm{O}$ segundo evento, ocorrido entre 0 Eoceno e Oligoceno, identificado por juntas de distensão NE-SW e falhas 
escalonadas de direção ENE-WSW, com bloco sul abatido, teria sido distensional Posteriormente, durante o Mioceno, teria ocorrido à fase mais marcante no maciço, associada a famílias de juntas de distensão, conjugadas de cisalhamento e espectros de juntas, além de falhas orientadas entre NESW, ENE-WSW e NNW-SSE, que indicariam um paleocampo de tensões transcorrente sinistral, com esforço máximo orientado a NE-SW.Finalmente, marcado pela transcorrência destral resultante de tensão principal orientada próxima a NW-SE, a fase quatro, ocorrida no Pleistoceno, seria representada por juntas de distensão, conjugadas híbridas e de cisalhamento, além de falhas transcorrentes orientadas segundo WNW-ESE.

\subsubsection{ANÁLISE CINEMÁTICA E PALEOTENSÕES ASSOCIADAS À ZONA DE CISALHAMENTO JUNDIUVIRA NO MACIÇO ALCALINO DE PASSA QUATRO}

No presente trabalho o estudo do paleocampo de tensões no Maciço Alcalino de Passa Quatro foi realizado empregando-se dados de diques de rochas alcalinas mapeados por Chiessi (2004). Este autor reconheceu no maciço diques petrograficamente caracterizados como fonolito, nefelina microssienito e lamprófiro.

Embora diversos autores tenham relacionado à colocação do Maciço Alcalino de Passa Quatro, a direção do eixo maior do corpo, segundo ENEWSW é paralela ao traçado da ZCJ, que interfere na sua porção sul. Os diques mapeados por Chiessi (2004) estão nitidamente concentrados no prolongamento da ZCJ para o interior do maciço. Este fato sugere um vínculo entre as colocações dos diques e a atividade tectônica ao longo da ZCJ.

- No diagrama de roseta e no histograma (figura 53) estão representadas as direções de todos os diques de rochas alcalinas. A observação dos gráficos mostra que, para um total de 33 diques, a moda encontra-se em N40-50W, o que indica $\sigma_{3}$ orientado na direção NE-SW. 

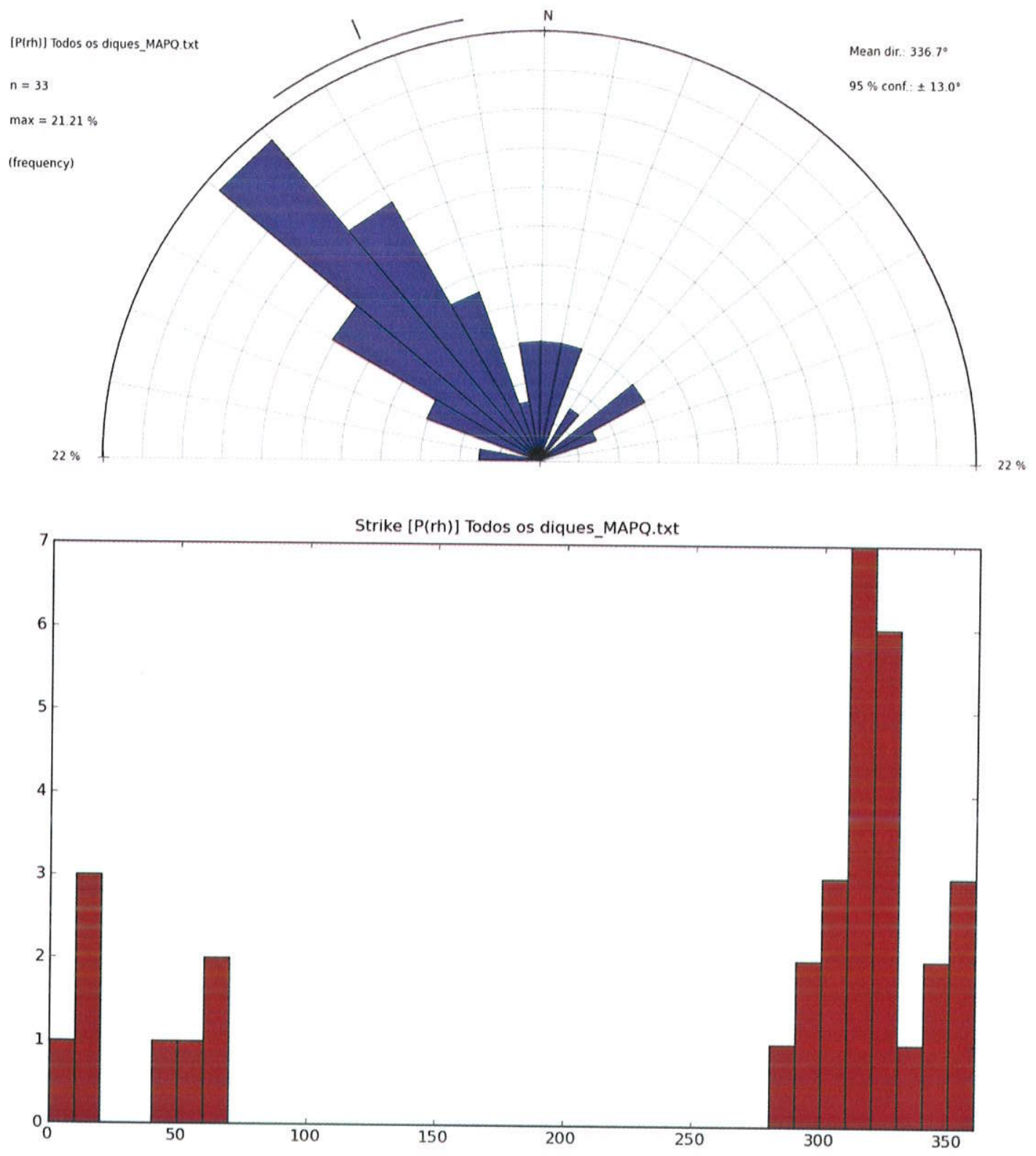

Figura 50 - Gráfico de roseta e histograma representando as direções para todos os diques do Maciço Alcalino de Passa Quatro.

Em seu trabalho, Chiessi (2004) propôs que a intrusão dos diferentes diques seria contemporânea à do corpo principal e estaria ligada a uma primeira fase trancorrente sinistral, relacionada a um binário de direção E-W, com $\sigma_{1}$ orientado na direção NE-SW. Esse seria o mesmo regime de esforços proposto para o Alinhamento Magmático de Cabo Frio. Os diques do interior do maciço estariam, portanto, em desacordo (ortogonais) com a direção do esforço principal máximo, o que levou Chiessi (2004) a propor como alternativa 
para essas direções de diques a influência de agentes externos às tensões, como pressão do magma ou intrusões próximas a superfície, além de, possivelmente, as intrusões terem ocorrido aproveitando-se de falhas sintéticas e antitéticas $P$ e $X$, respectivamente. Porém, um regime de esforços com $\sigma_{1}$ orientado próximo a NW-SE e $\sigma_{3}$ na direção NE-SW, além da direção geral do maior eixo do batólito ENE-WSW, paralela a elongação das megaestruturas do embasamento no sudeste do Brasil, permite considerar a hipótese da influência da cinemática na ZCJ na colocação dos diques, não considerada anteriormente.

Quando analisados por composição litológica (figura 54), os diques mostram diferenças notáveis nas direções dominantes: WNW-ESE para os diques de nefelina microssienito; NW-SE para os de fonolito; e NE-SW para os de lamprófiro. Essa disposição mostra que os diques de nefelina microssienito e de fonolito seriam compativeis com deslocamento destral ao longo da ZCJ, enquanto que os de lamprófiro mostrariam coerência com deslocamento sinistral ao longo do Alinhamento Magmático de Cabo Frio. 

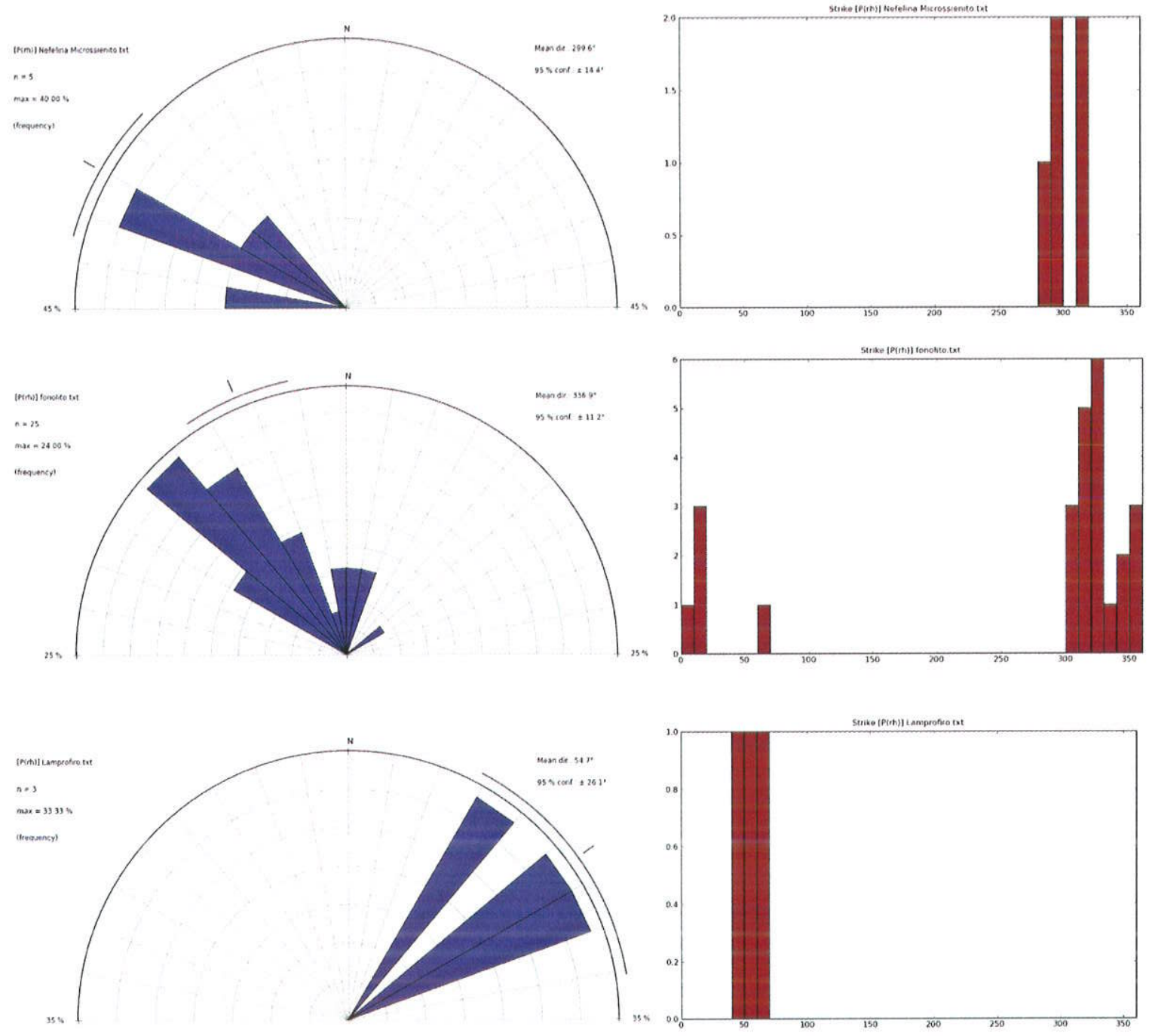

Figura 51 - Diagramas rosetas e histogramas referentes às principais frequências nas direções de orientação dos diques: a) nefelina microssienito; b) fonolito; e c) lamprófiro. 


\section{DISCUSSÕES}

As áreas selecionadas para estudo das reativações tectônicas ocorridas ao longo da ZCJ durante o fanerozoico mostraram deformações de diferentes idades.

No Ediacarano-Cambriano, a instalação da Bacia do Pico de Itapeva certamente foi condicionada pela atividade da ZCJ, seja ela uma bacia do tipo pull-apart (Riccomini 1993), bacia distensiva associada à zona transcorrente (ou strike slip basin) (Teixeira 2000), ou distensional (Almeida et al. 2010). Os três modelos admitiriam uma direção de distensão NW-SE ao longo da ZCJ, no Ediacarano-Cambriano.

A inversão da Bacia do Pico de Itapeva pode ser examinada a partir de um maior número de dados. Ela teria ocorrido sob regime compressivo (convergente obliquo), de direção E-W a WNW-ESE, provavelmente durante o Ordoviciano, a julgar por idades recentemente obtidas para a aglutinação final do Paleocontinente Gondwana Ocidental (e.g. Tohver et al. 2010).

O Granito de Itu apresentou população de falhas rúpteis transcorrentes, conjugadas, que indicam direção de encurtamento NNE-SSW. As estruturas descritas são estritamente rúpteis, caracterizando um evento posterior à colocação das rochas e resfriamento do magma, ocorrido há $580-590 \mathrm{Ma}$, e seu alçamento (ou exumação) para o nível crustal rúptil. Admite-se, portanto, que esta deformação seja no mínimo pós-ediacarana. Por outro lado, esta direção de encurtamento encontra paralelo, unicamente, com a penúltima deformação registrada em rochas do Grupo Itararé, em exposição situada nas proximidades e ao longo da $\mathrm{ZCJ}$. Tal fato sugere a vigência de um regime compressivo de direção NNE-SSW, posterior ao granito e sua exumação e anterior à deposição permocarbonifera e, portanto, não registrado nas rochas do Grupo Itararé na região de Itu.

Nas rochas permocarboniferas do Grupo Itararé da região de Itu foram observadas pelo menos seis diferentes gerações de falhas, todas rúpteis e póssedimentares. As quatro primeiras, de caráter normal, apresentam, sucessivamente, direções de distensão: A) NNE-SSW a NE-SW; B) NE-SW; C) WSW-ENE; e D) NNW-SSE. Esta sucessão sugere fortemente que tenha ocorrido rotação horária de $\sigma 3$, mantendo-se $\sigma 1$ na posição vertical. Todas 
elas são pós-sedimentares e, portanto, pós-permocarboníferas, e indicam distensão ortogonal ou oblíqua à ZCJ na região. Não há registro de intrusões de rochas básicas, relacionadas ao magmatismo eocretáceo da Formação Serra Geral nessas estruturas, as quais são relativamente frequentes na região da Depressão Periférica Paulista. Este fato sugere que as deformações tenham ocorrido após o Eocretáceo. Por outro lado, direções gerais de distensão NE$\mathrm{SW}$, como aquelas registradas pelas familias $A$ e $B$, foram reportadas em rochas neocretáceas dos maciços alcalinos de Cananéia (Riccomini 1995) e também de Passa Quatro, como registradas no presente trabalho. Direções gerais de distensão NW-SE são registradas durante a instalação do Rift Continental do Sudeste do Brasil, no Eoceno-Oligoceno, e durante o primeiro evento deformador, a transcorrência sinistral de idade miocena (Riccomini 1989, Riccomini et al. 2004).

A deformação compressiva, de direção NW-SE, apresenta direção distinta e sentido de transporte oposto àqueles registrados pelas deformações glaciotectônicas (e.g. Rocha-Campos et al. 2000) e superfícies estriadas (e.g. Gesicki et al. 2002) do intervalo glacial permocarbonífero da Bacia do Paraná. Adicionalmente, essa deformação é pelo menos mais jovem do que a familia de falhas normais $\mathrm{C}$, que já representam um terceiro evento distensivo, póssedimentar. Esta deformação implicaria em deslocamento destral ao longo da ZCJ, tendo em vista a sua direção NW-SE, sob a Bacia do Paraná, nesta região. Regionalmente, direção de compressão NW-SE encontraria correspondência no evento deformador transcorrente destral, de idade Pleistoceno terminal a Holoceno, do Rift Continental do Sudeste do Brasil (Riccomini 1989, Riccomini et al, 2004).

A deformação final registrada nas rochas do Grupo Itararé corresponde à compressão NNE-SSW a N-S. Embora pouco representativa, encontra boa correspondência com as direções de encurtamento mais recentes registradas na Bacia do Paraná (Riccomini \& Assumpção 1999).

Vale ressaltar que, ao menos na região de $\mathrm{Itu}$, as rochas da Bacia do Paraná (Grupo Itararé) apresentam sucessivas deformações de ordem tectônica e pós-sedimentares, sem qualquer vínculo com deformações glaciotectônicas penecontemporâneas à sedimentação, como antes admitido. 
No Maciço Alcalino de Passa Quatro os diques de nefelina microssienito mostram direções de distensão segundo NNE-SSW a NE-SW, o que implicaria em deslocamento transcorrente destral da ZCJ durante suas colocações, no Neocretáceo. Diques de lamprófiro, por sua vez, são compativeis com distensão de direção NW-SE e mostram relação com deslocamento transcorrente sinistral ao longo do Alinhamento Magmático de Cabo Frio. Esta observação resolve a incongruência constatada por Chiessi (2004) entre as direções dos diques de nefelina microssienito e de fonolito com o sentido de deslocamento esperado ao longo do Alinhamento Magmático de Cabo Frio. Embora não haja datações para os dois tipos de diques associados à ZCJ, é possivel que eles registrem uma evolução na rotação dos eixos principais de esforços, no sentido horário. Essa rotação foi observada em enxames de diques alcalinos, com idade cretácea, no segmento central do Rift de Assunção, leste do Paraguai, onde Velázquez et al. (2010) analisou a mudança nas direções principais de diferentes enxames de diques, comparando com análises petrográficas e relações temporais no campo, estimando o fracionamento progressivo do magma e a rotação do esforços horizontal mínimo. A disponibilidade futura de datações poderá comprovar ou não esta hipótese.

No Planalto de Campos do Jordão foram registradas deformações quaternárias em diferentes eventos deformacionais (Hiruma 1999, ModenesiGauttieri et al. 2001, Hiruma et al. 2001). No presente trabalho constatou-se que deformações relacionadas a uma compressão de direção NW-SE causaram o embutimento tectônico de depósitos coluviais e horizontes de paleossolos intercalados, de idade pleistocena tardia. A alternância de quatro niveis coluviais e de paleossolos sugere que o embutimento foi progressivo e concomitante à geração de espaço, relacionado à atividade tectônica da ZCJ. Dois eventos de falhamento ocorreram com intervalo aproximado de 2.000 anos, como indicado por paleossolos de $23.820 \pm 120$ e $21.660 \pm 270$ anos antes do presente. É possivel que estes eventos estivessem relacionados a sismos. Esse intervalo é da mesma ordem de grandeza que o previsto para sismos de magnitude 6 (700 anos) e 7 (7000) anos na região de New Madrid, no centroleste dos Estados Unidos (v.g. Wang 2006).

No caso das juntas neotectônicas e depósitos quaternários sobrepostos à ZCJ, verificou-se que elas foram geradas sob campos de esforços com 
SHmáx ora paralelo, ora ortogonal à ZCJ. Essas variações podem ser relacionadas à permutação de $\sigma 1$, normalmente na posição horizontal, para a posição vertical, por ocasião da descarga de esforços e/ou a deformações controladas por estruturas sintéticas e antitéticas da ZCJ. As deformações são as mais recentes encontradas ao longo da ZCJ, uma vez que interessam a depósitos datados de $3.410 \pm 80$ anos A.P. (Hiruma et al. 2001). Fato notável é que essas deformações distribuem-se de forma provavelmente contínua, por pelo menos $10 \mathrm{~km}$ ao longo do comprimento da ZCJ, e em diferentes posições em relação à sua dimensão transversal. Esta foi à única região passivel de estimativa da distribuição e extensão da reativação quaternária ao longo da Zona de Cisalhamento de Jundiuvira, o que certamente apresenta implicações para estimativas de magnitude de sismos ocorridos no Holoceno. 


\section{CONCLUSÕES}

Neste trabalho procurou-se caracterizar diferentes episódios de reativação fanerozoica ocorridos ao longo da Zona de Cisalhamento de Jundiuvira.

A definição do traçado ZCJ foi efetuada com base na compilação de trabalhos prévios e análise de modelos digitais de elevação elaborados a partir de dados do Shuttle Radar Topography Mission. Pequenas variações locais foram verificadas, em função das diferentes escalas de mapeamento, erros cartográficos ou diferentes interpretações das estruturas superficiais, possivelmente resultantes do retrabalhamento da megaestrutura.

A análise de modelos digitais de elevação, combinado com mapas de relevo sombreado, indicou que o traçado escolhido para a execução deste trabalho, representado pelo mapa geológico do Estado de São Paulo (CPRM 2006), apresenta grande concordância com a expressão geomorfológica curvilínea da ZCJ. Nessa análise ficou evidente o progressivo desaparecimento das feições geomorfológicas associadas à ZCJ (alinhamento de cristas e vales) sob as rochas sedimentares da Bacia do Paraná, na porção oeste, e uma aparente continuidade da estrutura para o Estado de Minas Gerais, a leste.

Os levantamentos de campo e a análise de dados preexistentes permitiram confirmar, nas áreas selecionadas para estudo, a existência de reativações tectônicas de diferentes idades e regimes tectônicos ao longo da ZCJ. Foram reconhecidas deformações sin-magmáticas de idade neocretácea e sin-sedimentares de idade pleistocena. Outras deformações tiveram suas idades estabelecidas com base em correlações regionais.

As deformações de idade fanerozoica reconhecidas podem ser assim sumarizadas:

1) distensão de direção NW-SE no Ediacarano-Cambriano, concomitante à instalação da Bacia do Pico de Itapeva; 
2) transpressão destral, com encurtamento na direção E-W a WNWESE, verificada na inversão da Bacia do Pico de Itapeva, de provável idade ordoviciana;

3) regime transcorrente destral, de direção NE-SW, e idade neocretácea, registrado pela intrusão de diques no Maciço Alcalino de Passa Quatro e, provavelmente, em rochas sedimentares do Grupo Itararé, na região de Itu;

4) distensão de direção geral NW-SE, também registrada em rochas sedimentares do Grupo Itararé, na região de Itu, e correlacionadas ao evento de instalação do Rift Continental do Sudeste do Brasil, no Eoceno-Oligoceno, ou ao primeiro evento deformador do rift, de transcorrência sinistral, de idade miocena;

5) compressão de direção NW-SE, em regime transcorrente destral, registrado por falhas provavelmente cossísmicas do Planalto de Campos do Jordão, de idade Pleistoceno terminal a Holoceno; provável correspondência com igual direção de compressão, registrada em rochas do Grupo Itararé, na região de ltu;

6) deformações com SHmáx orientado segundo as direções NE-SW e NW-SE, de idade holocena, em depósitos coluviais dispostos sobre a ZCJ no Planalto de Campos do Jordão; as variações de SHmáx estão provavelmente relacionadas à permutação de $\sigma 1$, normalmente na posição horizontal, para a posição vertical, por ocasião da descarga de esforços e/ou a deformações controladas por estruturas sintéticas e antitéticas da ZCJ.

No Grupo Itararé foi ainda constatada deformação relacionada à compressão de direção NNE-SSW a N-S, a qual, embora representada por uma única falha, mostra correspondência com as direções de encurtamento mais recentes registradas na Bacia do Paraná (Riccomini \& Assumpção 1999).

Outras conclusões importantes do trabalho referem-se ao fato de que na região de Itu as deformações encontradas em rochas do Grupo Itararé não apresentam relação com glaciotectonismo. O reconhecimento da ação da ZCJ na colocação de diques de rochas alcalinas de direções gerais NW-SE resolve - aparente paradoxo de sua incompatibilidade com os regimes tectônicos 
vigentes ao longo do Alinhamento Magmático de Cabo Frio durante o Neocretáceo e Eoceno. No Planalto de Campos do Jordão, além da identificação de falhas possivelmente cossísmicas e com intervalo de recorrência da ordem de $10^{3}$ anos, pode ser verificada a provável continuidade da distribuição dos depósitos coluviais falhados por pelo menos $10 \mathrm{~km}$ ao longo do traçado da ZCJ, com implicações em termos da paleossismicidade regional. As deformações quaternárias neste planalto estão provavelmente relacionadas às estruturas sintéticas e antitéticas à ZCJ.

Os resultados obtidos permitiram melhorar significativamente 0 conhecimento sobre a evolução fanerozoica da $\mathrm{ZCJ}$, com implicações para as demais zonas de cisalhamento do sudeste do Brasil. O refinamento desses dados depende, de um lado, do reconhecimento de novas ocorrências de rochas datáveis e de estruturas sin-magmáticas e sin-sedimentares e, de outro, da disponibilidade de dados geocronológicos. 


\section{REFERÊNCIAS BIBLIOGRÁFICAS}

ALGARTE, J.P., CUNHA, H.C.S., DAITX, E.C. CHIEREGATI, L.A, CAVALCANTE, J.C. 1974. In: Projeto Sudeste do estado de São Paulo: relatório geológico final - folha São Paulo-SF.23-Y-C. São Paulo, 4 v.

ALMEIDA, F.F.M. 1953. Considerações sobre a geomorfogênese da Serra de Cubatão, Boletim da Sociedade Brasileira de Geologia, 4:23-40.

ALMEIDA, F.F.M. 1955. As camadas de São Paulo e a tectônica da Serra da Cantareira. Boletim da Sociedade Brasileira de Geologia, 4:23-40.

ALMEIDA, F.F.M. 1967. Origem e evolução da Plataforma Brasileira. Rio de Janeiro, DNPM/DGM, 241, $36 \mathrm{p}$.

ALMEIDA, F.F.M. 1969. Diferenciação tectônica da Plataforma Brasileira. In: Congresso Brasileiro de Geologia, 23,Salvador-BA. Anais, 1:29-46.

ALMEIDA, F.F.M. 1976. The system of continental rifts bordering the Santos Basin, Brazil. In: Academia brasileira de ciências, 4:15-26 (Suplemento).

ALMEIDA, F.F.M. 1983. Relações tectônicas das rochas alcalinas mesozóicas na região meridional da Plataforma Sul-Americana. Revista Brasileira de Geociências, 13:139-158.

ALMEIDA, F.F.M. 1991. O alinhamento magmático de Cabo Frio. In: Simpósio de Geologia do Sudeste, 2, São Paulo. Atas, $423-428$.

ALMEIDA, F.F.M. \& CARNEIRO, C.D.R. 2004. Inundações marinhas fanerozóicas no Brasil e recursos minerais associados. In: Mantesso-Neto, V., Bartorelli, A., Carneiro, C.D.R., Brito Neves, B.B., (Orgs.). Geologia do Continente SulAmericano: evolução da obra de Fernando Flávio Marques de Almeida. São Paulo, 43-58.

ALMEIDA, F.F.M.; HASUI, Y.; BRITO NEVES B.B.; Fuck, R.A. 1981. Brazilian structural provinces: an introduction. Earth-Science Reviews, 17:1-21. 
ALMEIDA, R.P.; JANIKIAN, L., FRAGOSO-CESAR, A.R.S.; FAMBRINI, G.L. 2010. The Ediacaran to Cambrian Rift System of Southeastern South America: Tectonic Implications. In: The Journal of Geology, The University of Chicago Press, 2010, 116:145-161.

ANDERSON, E.M. 1951. The dynamics of faulting and dyke formation with applications to Britain. Edinburg: Oliver \& Boyd, 206 p.

ANGELIER, J. 1984. Tectonic analysis of fault slip data sets. Journal of Geophysical Research, 89:5835-5848.

ANGELIER, J. 1994. Fault slip analysis and paleostress reconstruction. In: HANCOCK, P.L. (ed). Continental Deformation, Oxford: Pergamon Press, 53-100.

ANGELIER, J. \& MECHLER, P. 1977. Sur une method graphique de recherché des contraintes principales, egalements utilizable en tectonique et en seismologie: la method des diédres droits. Bulletin de la Société Géologique de France, 7:1309-1318.

ASMUS, H.E. 1978. Hipóteses sobre a origem dos sistemas de zonas de fratura oceânica/alinhamentos continentais que ocorrem nas regiões Sudeste e Sul do Brasil. Projeto REMAC, 4:39-73.

ASMUS, H.E. \& FERRARI, A.L. 1978. Hipóteses sobre a causa do tectonismo cenozóico na região sudeste do Brasil. Projeto REMAC, 4:75-88.

ASSUMPÇÃO, M. 1992. The regional intraplate stress field in South America. Journal of Geophysical Research, 97:11889-11903.

ASSUMPÇÃO, M. 1998. Focal mechanisms of small earthquakes in the southeastern Brazilian shield: a test of stress models of the South American plate. Geophysical Journal International, 133:490-498.

ASSUMPÇÃO, M.; DIAS NETO, C.M.; BERROCAL, J.; ANTEZANA, R.; FRANÇA, H.; ORTEGA, R. 1980. Sismicidade do sudeste do Brasil. In: Congresso Brasileiro de Geologia, 23, Balneário Comburiu - SC, 1980. Anais, 2:10751092. 
CAINE, J.S.; EVANS, J.P.; FORSTER, C.B. 2009. Fault zone architecture and permeability structure. Geology, 24:1025-1028.

CAMPANHA, G.A.C., 2002. O papel das zonas de cisalhamento transcorrentes na configuração da porção meridional da Faixa Ribeira. São Paulo, IGc-USP, Tese de Livre Docência, 105 p.

CAMPOS NETO, M.C. 1991. A porção ocidental da Faixa Alto Rio Grande: ensaio de evolução tectônica. Instituto de Geociências, Universidade de São Paulo, São Paulo, Tese de Doutorado, 210 p.

CAMPOS NETO, M.C. \& BASEI, M.A.S. 1983. Evolução estrutural brasiliana do nordeste de São Paulo: dobramentos superpostos e esboço estratigráfico e tectônico. In: Simpósio Regional de Geologia, 4, São Paulo, 1983, Atas, 1:61-78.

CANUTO J.R., ROCHA-CAMPOS A.C., SANTOS P.R. 1997. Sequence stratigraphy of the Itararé Subgroup (Late Paleozoic), Paraná Basin, in southern Paraná and northern Santa Catarina, Brazil. In: Simpósio sobre Cronoestratigrafia da Bacia do Paraná, 3, Barra do Garças, Atas, 18-19.

CAPUTO, R.A. 1995. Evolution of orthogonal sets of coeval extension joints. Terra nova, 7:479-490.

CARNEIRO, C.D.R. 1977. Geologia e Evolução Geológica da Folha São José dos Campos. Instituto de Geociências, Universidade de São Paulo, São Paulo, Dissertação de Mestrado, $106 \mathrm{p}$.

CASTRO, J.C. 2004. Glaciações Paleozóicas no Brasil. In: Mantesso-Neto, V., Bartorelli, A., Carneiro, C.D.R., Brito Neves, B.B., (Orgs.). Geologia do Continente Sul-Americano: evolução da obra de Fernando Flávio Marques de Almeida, 151 - 163.

CAVALCANTE, J.C. \& KAEFER, L.Q. 1974. Geologia da Folha de Santos (parcial). In: Congresso Brasileiro de Geologia, 28, Porto Alegre - RS, Anais, 4:227245. 
CAVALCANTE, J.C., YAMAMOTO, K., ALGARTE, J.P. ET AL. 1979. Projeto Sapucai - folha Varginha SF.23-V-D escala 1:250.000. Brasilia, Departamento Nacional de Produção Mineral-Companhia de Pesquisa de Recursos Minerais, 299 p. (Série Geologia, 4).

CHAMANI, M.A.C.; MARTIN, M.A.B.; RICCOMINI, C. 1992. Estruturas de liquefação induzidas por abalos sísmicos no permo-triássico da Bacia do Paraná, Estado de São Paulo, Brasil. In: Congresso Brasileiro de Geologia, 37, São Paulo. Boletim de Resumos Expandidos, 2:508-510.

CHIESSI, C.M. 2004. Tectônica cenozóica do Maciço Alcalino de Passa Quatro (SP-MG-RJ). Instituto de Geociências, Universidade de São Paulo, São Paulo, Dissertação de Mestrado, $117 \mathrm{p}$.

COLBLENTZ, D.D. \& RICHARDSON, R.M. 1996. Analysis of the South American intraplate stress field. Journal of Geophysical Research, 101:8643-8657.

CORDANI, U.G.; BRITO-NEVES, B.B.; FUCK, R.A.; PORTO, R., THOMAZ-FILHO, A., CUNHA, F.M.B. 1984. Estudo preliminar de integração do pré-cambriano com os eventos tectônicos das bacias sedimentares brasileiras. CEMPES/SINTEP, Petrobras, 63-65.

CPRM 2006. Mapa Geológico do Estado de São Paulo. Escala $1: 750.000$. Serviço Geológico do Brasil - CPRM. Breve descrição das unidades litoestratigráficas aflorantes no estado de São Paulo, 195 p.

DUNNE, W.M. \& HANCOCK, P.L. 1994. Paleostress analysis of small-scale brittle structures. In: HANCOCK, P.L. (ed). Continetal Deformation. Oxford: Pergamon Press, $101-120$.

EBERT, H.D. \& HASUI, Y. 1998. Transpressional tectonics and strain partitioning during oblique collision between three plates in the Precambrian of southeast Brazil. In: HOLDSWORTH, R.A. \& DEWEY, J.F. (eds) 1998. Continental Transpressional and Transtensional Tectonics. Geological Society, London, Special Publications, 135:231-252. 
EBERT, H.D.; HASUI, Y.; COSTA, J.B.S. 1991. O caráter transpressivo do cinturão transcorrente Rio Paraíba do Sul. In: Simpósio Nacional de Estudos Tectônicos, 3., Rio Claro, 1991. Boletim de Resumos Expandidos, Roteiros e Excursões, 139-141.

EMBRAPA, 2011. Brasil em Relevo

http://www.relevobr.cnpm.embrapa.br/download/index.htm

FERNANDES DA SILVA, P.C. 1998. Tectônica rúptil da região entre Pilar do Sul e Votorantim - SP. Revista Brasileira de Geociências, 28:485-494.

FERRARI, A.L. 2001. Evolução tectônica do Graben da Guanabara. Instituto de Geociências, Universidade de São Paulo, São Paulo, Tese de Doutorado, $412 \mathrm{p}$.

FRANÇA, A.B., POTTER, P.E. 1988. Estratigrafia, ambiente deposicional e análise de reservatório do Grupo Itararé (Permocarbonífero), Bacia do Paraná (Parte 1). Boletim de Geociências da Petróleo Brasileiro S.A., 2:147-191.

FREITAS, R.O. 1951. Ensaio sobre a tectônica moderna do Brasil. Boletim FFCL USP, 6, $120 \mathrm{p}$.

GALEMBECK, T.M.B. 1991. Aspectos geológicos, petrográficos e geoquímicos da intrusão Cabreúva - complexo granitóide de Itu, São Paulo. Instituo de Geociências e Ciências Exatas, Universidade Estadual Paulista, Rio Claro, Dissertação de Mestrado, 195 p.

GARCIA, M.G.M. \& CAMPOS NETO, M.C. 1997. Superposição destral em ampla zona de cisalhamento sinistral: Cinturão de Cisalhamento São Paulo, imediações de Piracaia - SP. Revista Brasileira de Geociências, 27:339-348.

GEISICK, A.L.D.; RICCOMINI, C.; BOGGIANI, P.C. 2002. Ice flow direction during late Paleozoic glaciation in western Paraná Basin, Brazil. Journal of South American Earth Sciences, 14:933-939.

GEOFFROY, L.; BERGERAT, F.; ANGELIER, J. 1993. Modification d un champ de contrainte regional par un champ de contraintes magmatique local. Exemple de l'ile de Skye (Ecosse) au Paléocène. Bulletin de la Société Géologique de France, 164:541-552. 
GROHMANN, C.H. \& CAMPANHA, G.A.C. 2010. OpenStereo. Open source, crossplatform software for structural geology analysis. http://www.igc.usp. br/index.php?id=391.

GROHMANN, C.H. \& CAMPANHA, G.A.C. 2010. OpenStereo: Open Source, CrossPlatform Software for Structural Geology Analysis. Fall Meeting, San Francisco

HANCOCK, P.L. 1985. Brittle microtectonics: principles and pratice. Journal of Structural Geology, 7:437-457.

HARTWING, M.E.; RICCOMINI, C. 2009. Padrão de fraturas da região da Serra dos Órgãos (RJ) e sua relação com a tectônica mesozóica-cenozóica do sudeste do Brasil. Revista Brasileira de Geociências, 39:452-464.

HASUI, Y. 1973. Tectônica da área das folhas de São Roque e Pilar do Sul. Instituto de Geociências, Universidade de São Paulo, São Paulo, Tese de Livre Docência, $190 \mathrm{p}$.

HASUI, Y. 1975. Evolução polifásica do Pré-Cambriano oeste da capital paulista. Boletim Instituto de Geociências - USP, 6:95-107.

HASUI, Y. \& PONÇANO, W.L. 1978. Geossuturas e sismicidade no Brasil. In: Congresso Brasileiro de Geologia de Engenharia, 2, São Paulo, 1978. Anais, $1: 331-338$.

HASUI, Y. \& SADOWSKI, G.R. 1976. Evolução Geológica do Pré-Cambriano na região sudeste do Estado de São Paulo. Revista Brasileira de Geociências, $6: 182-200$.

HASUI, Y.; ALMEIDA, F.F.M. de; MIOTO, J.A.; MELO, M.S. 1982. Geologia, tectônica, geomorfologia e sismologia regionais de interesse às usinas nucleares da praia de Itaorna. São Paulo, Instituto de Pesquisas Tecnológicas do Estado de São Paulo S.A., Monografias n7, 149 p.

HASUI, Y.; CARNEIRO, C.D.R.; COIMBRA, A.M. 1975. The Ribeira Folded Belt. Revista Brasileira de Geociências. São Paulo, 5:257-262. 
HASUI, Y.; CARNEIRO, C.D.R.; BISTRICHI, C.A. 1980. Estruturas e Tectônica do Pré-Cambriano de São Paulo e Paraná. In: Anais da Academia Brasileira de Ciências, 52:61-76.

HASUI, Y.; CARNEIRO, C.D.R.; BISTRICHI, C.A. 1978 a. As estruturas brasilianas. In: Congresso Brasileiro de Geologia, 30, Recife-PE. Anais, 6:2423-2437.

HASUI, Y.; DANTAS, A.S.L.; CARNEIRO, C.D.R.; BISTRICHI, C.A. 1981. O embasamento Pré-Cambriano e Eopaleozóico em São Paulo. In: Mapa Geológico do Estado de São Paulo: escala 1:500.000. Governo do Estado de São Paulo, Secretaria da Indústria, Comércio, Ciência e Tecnologia. Divisão de Minas e Geologia Aplicada, IPT, 12-45.

HASUI, Y.; FONSECA, M.G.; RAMALHO, R. 1984. A parte central da região de dobramentos sudeste e Maciço Mediano de Guaxupé. In: SCHOBBENHAUS, C.; CAMPOS, D.A.; DERZE, G.R \& ASMUS, H.E. (ed.). Geologia do Brasil. DNPM/DGM. Brasilia, 307-328.

HASUI, Y.; PENALVA, F.; HENNIES, W.T. 1969. Geologia do Grupo São Roque. In: Congresso Brasileiro de Geologia, 23, Salvador. Anais, 101-134.

HASUI, Y.; PONÇANO, W.L.; BISTRICHI, C.A.; STEIN, D.P.; GALVÃO, C.A.C.F.; GIMENEZ, A.F.; ALMEIDA, M.A.; MELO, M.S. \& PIRES NETO, A.G. 1978 b. As grandes falhas do leste paulista. In: Simpósio Regional de Geologia, 1, São Paulo - SP. Atas, 369-438.

HASUI, Y.; PONÇANO, W.L.; STEIN, D.P.; MELO, M.S. 1978. Os falhamentos e a sismicidade natural da região das Serras da Mantiqueira e do Mar. In: Congresso Brasileiro de Geologia de Engenharia, 2, São Paulo - SP. Anais, 1:353-357.

HEILBRON, M.; PEDROSA-SOARES, A.C.; CAMPOS NETO, M.C.; SILVA, L.C. DA; TROUW, R.A.J; JANASI, V.A. 2004. Provincia Mantiqueira. In: Mantesso-Neto, V., Bartorelli, A., Carneiro, C.D.R., Brito Neves, B.B., (Orgs.). Geologia do Continente Sul-Americano: evolução da obra de Fernando Flávio Marques de Almeida, 487-536. 
HENNIES, W.T.; HASUI Y.; \& PENALVA, F. 1967. O falhamento transcorrente de Taxaquara. In: Congresso Brasileiro de Geologia, 31, Curitiba - PR. Anais, 159-168.

HIRUMA, S.T. 1999. Neotectônica no Planalto de Campos do Jordão, SP. Instituto de Geociências, Universidade de São Paulo, São Paulo, Dissertação de Mestrado, $102 \mathrm{p}$.

HIRUMA, S.T.; RICCOMINI, C.; MODENESI-GAUTTIERI, M.C. 2001. Neotectônica no Planalto de Campos do Jordão, SP. Revista Brasileira de Geociências. São Paulo, 31:375-384.

IAG 2011. : Mapa de Sismicidade do Sudeste do Brasil em escala 1:5.000.000. In: http://www.sismo.iag.usp.br/sismologia/sismicidadeBR.php. Acessado em julho/2011.

IPT 1981. Mapa Geológico do Estado de São Paulo. Escala 1:500.000, texto. IPTPublicação 1184, Série Monografias, 6, São Paulo, IPT, 2 V.

JANASI, V.A.; VLACH, S.R.F.; CAMPOS NETO, M.C.; ULBRICH, H.H.G.J. 2009. Associated a-type subalkaline and high-k calc-alkaline granites in the Itu granite province, southeastern Brazil: petrological and tectonic significance. The Canadian Mineralogist, 47:1505-1526.

JULIANI, C., 1993. Geologia, petrogênese e aspectos metalogenéticos dos grupos Serra do Itaberaba e São Roque nas regiões das Serras de Itaberaba e Pedra Branca, NE da cidade de São Paulo (SP). Instituto de Geociências, Universidade de São Paulo, São Paulo, Tese de Doutorado, 803 p.

JULIANI, C.; BELJAVSKIS, P.; SCHORSCHER, H.D. 1986. Petrogênese do vulcanismo e aspectos metalogenéticos associados: Grupo Serra do Itaberaba na região de São Roque - SP. In: Congresso Brasileiro de Geologia, 34, Goiânia-GO. Anais, 2:730-743.

JULIANI, C.; RICCOMINI, C.; BARROS, E.J.; BATISTUCCI, N.L.N., 1990. Proterozoic storm-dominated sedimentation in the Pico do Itapeva Formation (São Paulo State, Brazil). Anais da Academia Brasileira de Ciências, 62:105. 
MACEDO, J.M. 1990. Evolução tectônica das bacias de Santos e áreas adjacentes. In: RAJA-GABAGLIA, G.P.G. \& MILANI, M.J. (eds). Origem e evolução de bacias sedimentares. Petrobras, 361-376.

MACHADO, R. \& ENDO, I. 1993. A megaestrutura em flor positiva do vale do rio Paraiba do Sul no Rio de Janeiro. In: Simpósio de geologia do sudeste, 3, Rio de Janeiro. Atas, 208-213.

MILANI, E.J. 1997. Evolução tectono-estratigráfica da Bacia do Paraná e seu relacionamento com a geodinâmica fanerozóica do Gonduana sul-ocidental. Universidade Federal do Rio Grande do Sul, Porto Alegre. Tese de Doutorado -2 volumes, $255 \mathrm{p}$.

MILANI, E.J. 2004. Comentários sobre a origem e evolução tectônica da Bacia do Paraná. In: Mantesso-Neto, V., Bartorelli, A., Carneiro, C.D.R., Brito Neves, B.B., Orgs.). Geologia do Continente Sul-Americano: evolução da obra de Fernando Flávio Marques de Almeida, 265-279.

MODENESI, M.C. 1984. Evolução quaternária de uma montanha tropical: o Planalto de Campos do Jordão, São Paulo. Revista do Instituto Geológico, 5:7-13.

MODENESI, M.C. 1988. Significado dos depósitos correlativos quaternários em Campos do Jordão - São Paulo: implicações paleoclimáticas e paleoecológicas. Boletim do Instituto Geológico, 7, 155 p.

MODENESI-GAUTTIERI, M.C.; HIRUMA, S.T.; RICCOMINI, C. 2002. Morphotectonics of a high plateau on the northwestern flank of the Continental Rift of Southeastern Brazil. Geomorphology, 43:257-271.

NEVES, M.A. 2005. Análise integrada aplicada à exploração de água subterrânea na bacia do Rio Jundiai. Instituto de Geociência e Ciências Exatas, Universidade Estadual de São Paulo, Rio Claro, Tese de Doutorado, 200 p.

PASCHOLATI, E.M.; Vlach, S.R.P.; Amaral, G. 1987. Contribuição ao conhecimento da suíte intrusiva Itu. In: Simpósio Regional de Geologia, 6, Rio Claro, Atas, 1:47-62.

PETIT, J.P. 1987. Criteria for sense of movement on fault surfaces in brittle rocks. Journal of Structural Geology, 9:597-608. 
POLLARD, D.D. 1987. Elementary fracture mechanics applied to the structural interpretation of dykes. In: HALLS, H.C. \& FAHRIG, W.F. (eds). Mafic dykes swarms. Geological Association of Canada Special Paper, 34:5-24.

PRICE, N.J. \& COSGROVE, J.W. 1990. Analysis of geological structures. First edition. London: Cambridge University Press, 502 p.

RIBEIRO FILHO, J.G. 1967. Geologia e petrologia dos Maciços Alcalinos do Itatiaia e Passa Quatro. Boletim FFCL-USP, 22:5-94.

RICCOMINI, C. 1989. O Rift Continental do Sudeste do Brasil. Instituto de Geociências, Universidade de São Paulo, São Paulo, Tese de Doutorado, $256 p$.

RICCOMINI, C. 1993. Origem, evolução e inversão da Bacia do Pico do Itapeva, Neoproterozóico-Cambriano, São Paulo, Brasil. In: DINAMIGE-Fac. Agron., Simp. Intern. del Neoproterozóico-Cambrico de la Cuenca del Plata, 1, La Paloma-Minas, Resumenes Extensos, Tomol, res. 16.

RICCOMINI, C. 1995. Tectonismo gerador e deformador dos depósitos sedimentares pós-gondvânicos da porção centro-oriental do Estado de São Paulo e áreas vizinhas. Instituto de Geociências, Universidade de São Paulo, São Paulo, Tese de Livre-Docência, 100 p.

RICCOMINI, C. 1995. Padrão de fraturamentos do Maciço Alcalino de Cananéia, Estado de São Paulo: relações com a tectônica mesozóico-cenozóica do sudeste do Brasil. Revista Brasileira de Geociências, 15:79-84.

RICCOMINI, C. \& ASSUMPÇÃO, M. 1999. Quaternary tectonics in Brazil. Episodes, 22:221-225.

RICCOMINI, C; BRENTAN, S; TOMBA, C.L.B.; FERRARI, A. L.; TAIOLI, F; SILVA, T.B; MANOEL, D.F.C. 2006. Regime Tectônico de Colocação dos Enxames de Diques Eocretáceos do Sudeste do Brasil. In: XLIII Congresso Brasileiro de Geociências, 43, Aracajú-SE. Anais, 110.

RICCOMINI, C.; CHAMANI, M.A.C.; AGENA, S.S.; FAMBRINI, G.L.; FAIRCHILD, T.R.; COIMBRA, A.M. 1992. Earthquake-induced liquefaction features in the 
Corumbataí Formation Permian, Paraná Basin, Brazil and the dynamics of Gondwana. Anais da Academia Brasileira de Ciências, 64:210.

RICCOMINI, C., SANT'ANNA, L.G., FERRARI, A.L. 2004. Evolução geológica do Rift Continental do Sudeste do Brasil. In: Mantesso-Neto, V., Bartorelli, A., Carneiro, C.D.R., Brito Neves, B.B., (Orgs.). Geologia do Continente SulAmericano: Evolução da Obra de Fernando Flávio Marques de Almeida. São Paulo, Beca, p. 383-405.

RICCOMINI, C.; VELÁZQUEZ, V.F.; GOMES, C.B. 2005. Tectonics controls of the Mesozoic and Cenozoic alkaline magmatism in central-southeastern Brazilian Plataform. In: COMIN-CHIARAMONTI, P.; GOMES, C.B. (eds). Mesozoic to Cenozoic alkaline magmatism in the Brazilian Plataform. EDUSP-FAPESP, São Paulo, 1-26.

RICKWOOD, P.C. 1990. The anatomy of a dyke and the determination of propagation and magma flow directions. In: PARKER, J.; RICKWOOD, P.C., TUCKER, D.H. (eds). Mafic dykes and emplacement mechanics. Rotterdam: Balkema, 81-100.

RIEDEL, W. 1929. Zur Mechanik geologischer Brucherscheinungen. Zentralblatt fur Mineralogie, Geologie und Paleontologie, 1929B:354-368.

ROCHA CAMPOS, A.C.; CANUTO, J.R.; SANTOS, P.R. 2000. Late Paleozoic glaciotectonic structures in northern Paraná Basin, Brazil. Sedimentary Geology, 130:131-143.

ROLDAN, L.F. 2007. Tectônica meso-cenozóica na região do Domo de Lages, SC. Instituto de Geociências, Universidade de São Paulo, São Paulo, Dissertação de Mestrado, 121p.

SAADI, A. 1993. Neotectônica da Plataforma Brasileira: esboço e interpretações preliminares. Geonomos, 1:1-15.

SADOWSKI, G.R. 1974. Tectônica da Serra do Cubatão, SP. Instituto de Geociências, Universidade de São Paulo, São Paulo, Tese de Doutorado, $158 \mathrm{p}$. 
SADOWSKI, G.R. 1977. Reativação do embasamento da Faixa de Dobramentos Ribeira na região da Serra de Cubatão. Boletim IG/USP, 8:67-76.

SADOWSKI, G.R. 1993. Sobre a geologia estrutural de cinturões de cisalhamento continentais. Instituto de Geociências, Universidade de São Paulo, São Paulo, Tese de Livre-Docência, 108 p.

SADOWSKI, G.R. \& CAMPANHA, G.A.C. 2004. Grandes falhas do Brasil continental. In: Mantesso-Neto, V., Bartorelli, A., Carneiro, C.D.R., Brito Neves, B.B., (Orgs.). Geologia do Continente Sul-Americano: Evolução da Obra de Fernando Flávio Marques de Almeida. São Paulo, .Beca, p. $407-$ 421.

SADOWSKI, G.R. \& DIAS NETO, C.M. 1981. O Lienamento Sismo-Tectônico de Cabo Frio. Revista Brasileira de Geociências, 11:209-212.

SALVADOR, E.D. 1994. Análise neotectônica da região do Vale do Rio Paraíba do Sul compreendida entre Cruzeiro (SP) e Itatiaia (RJ). Instituto de Geociências, Universidade de São Paulo, São Paulo, Dissertação de Mestrado, $129 \mathrm{p}$.

SALVADOR, E.D. \& RICCOMINI, C. 1995. Neotectônica da região do Alto Estrutural de Queluz (SP-RJ, Brasil). Revista Brasileira de Geociências, 25:151-164.

SCHOBBENHAUS, C.; CAMPOS, D.A.; DERZE, G.R.; ASMUS, H.E. 1984. Geologia do Brasil: Texto explicativo do mapa geológico do Brasil e da área oceânica adjacente, incluindo depósitos minerais, escala 1:2.500.000. Brasilia, MMe-DNPM, 501 p.

SCHOBBENHAUS FILHO, C. 1981. Carta geológica do Brasil, 1:2.500.000. Brasilia, DNPM.

SILVA, T.B. O uso de corpos intrusivos como indicadores tectônicos: o enxame de diques Santos - Rio de Janeiro (Eocretáceo). In: XIII Simpósio Internacional de Iniciação Cientifica da Universidade de São Paulo - SIICUSP, 2005, São Carlos. Universidade de São Paulo.

SUMMERFIELD, M.A. 1993. Global Geomorphology: an introduction to the study of landforms. New York: Longman Scientific \& Technical, 537 p. 
STEWART, I.S. \& HANCOCK, P.L. 1994. Neotectonics. In: HANCOCK, P.L. (ed.). Continental Deformation. Oxford: Pergamon Press, 370-409.

SYLVESTER. G.A. 1988. Strike-slip faults. Geological Society of American Bulletin, 100:1666-1703.

TCHALENKO, R.N. 1970. Similarities between shear zones of different magnitudes. Geological Society of American Bulletin, 81:1625-1640.

TEXEIRA, A.L. 2000. Análise das bacias da transição Proterozóico-Fanerozóico do Estado de São Paulo e adjacências. Instituto de Geociências, Universidade de São Paulo, São Paulo, Tese de Doutorado, 158 p.

TEXEIRA. A.L.; GAUCHER, C.; PAIM, P.S.G.; FONSECA, M.M. da; PARENTE, C.V.P.; SILVA FILHO, W.F. da; ALMEIDA, A.R. de, 2004. Bacias do estágio da transição da Plataforma Sul-Americana. In: MANTESSO-NETO, V. et al. (orgs.). Geologia do Continente Sul-Americano: evolução da obra de Fernando Flávio Marques de Almeida, 487-536.

TOHVER, E.; TRINDADE, R.I.F.; SOLUM, J.G.; HALL, C.M.; RICCOMINI, C.; NOGUEIRA, A.C. 2010. Closing the Clymene ocean and bending a Brasiliano belt: Evidence for the Cambrian formation of Gondwana, southeast Amazon craton. Geology, 38:267-270.

TURRA, B.B., 2009. Diques clásticos da Formação Corumbataí, Bacia do Paraná, contexto da tectônica Permotriássica do Gondwana Ocidental. Instituto de Geociências, Universidade de São Paulo, São Paulo, Dissertação de Mestrado, $96 \mathrm{p}$.

WANG, Z. 2006. Understanding seismic hazard and risk assessments: ans example in the New Madrid Seismic Zone of the central United States. In: 8th U.S. National Conference on Earthquake Engineering, San Francisco, California, USA. Proceedings, paper 416, 10p.

WERNICK, E.; HASUI, Y., BRITO NEVES, B.B. 1978. As regiões de dobramentos nordeste e sudeste. In: Congresso Brasileiro de Geologia, 30, Recife-PE, 1978. Anais, 6:2493-2506. 
WILCOX, R.E.; HARDING, T.P.; SEELY, D.R., 1973. Basic wrench tectonics. Bulletin AAPG, 57:74-96.

ZALÁN, P.V.; WOLFF, S.; ASTOLFI, M.A.M.; VIEIRA, I.S.; CONCEIÇÃO, J.C.J.; APPI, V.T.; NETO, E.V.S.; CERQUEIRA, J.R.; MARQUES, A., 1990. The Paraná Basin, Brazil. In: LEIGHTON, M.W.; KOLATA, D.F; OLTZ, J.J. (eds.) Interior Cratonic Basins. American Association of Petroleum Geologist Memoir, 51:681-708.

ŽALOHAR, J. 2009. T-Tecto 3.0. Integrated software for structural analysis of faultslip data. http://www2.arnes. si/ izaloh/t-tecto homepage.htm.

ŽALOHAR, J., VRABEC, M. 2007. Paleostress analysis of heterogeneous fault-slip data: the Gauss method. Journal of Structural Geology, 29:1798-1810.

ZOBACK, M.L.1992. First and Second order patterns of stress in the lithosphere: The World Stress Map Project. Journal of Geophysical Reserch, 97(B8):11703-11728.

ZOBACK, M.L; ADAMS, J.; ASSUNÇÃO, M.; BELL, S; BERGMAN, E.A.; BLÜMLING, P.; BRERETON, N.R.; DENHAM, D.; DING, J.; FUCHS, K., GAY, N.;GREGERSEN, S.; GUPTA, H.K.; GVISHIANI, A.; JACOB, K.; KLEIN, R.; KNOLL, P.; MAGEE, M.; MERCIER, J.L.; MÜLLER, B.; PAQUIN, C.; RAJENDRAN, K.; STEPHANSSON, O.; SUAREZ, G.; SUTER, M.; UDIAS, A.; XU, Z.H.; ZHIZHIN, M. 1989. Global patterns of tectonic stress. Nature, 341:291-298. 